\title{
Archeological Investigations at the Polk Estates Site (41CP245), Camp County, Texas
}

Timothy K. Perttula

Heritage Research Center, Stephen F. Austin State University

Bo Nelson

Heritage Research Center, Stephen F. Austin State University

Follow this and additional works at: https://scholarworks.sfasu.edu/ita

Part of the American Material Culture Commons, Archaeological Anthropology Commons, Environmental Studies Commons, Other American Studies Commons, Other Arts and Humanities Commons, Other History of Art, Architecture, and Archaeology Commons, and the United States History Commons

Tell us how this article helped you.

This Article is brought to you for free and open access by the Center for Regional Heritage Research at SFA ScholarWorks. It has been accepted for inclusion in Index of Texas Archaeology: Open Access Gray Literature from the Lone Star State by an authorized editor of SFA ScholarWorks. For more information, please contact cdsscholarworks@sfasu.edu. 


\section{Archeological Investigations at the Polk Estates Site (41CP245), Camp County,}

Texas

\section{Creative Commons License}

\section{(c) (1) (8)}

This work is licensed under a Creative Commons Attribution-NonCommercial 4.0 International License 


\title{
Archeological Investigations at the Polk Estates Site (41CP245), Camp County, Texas
}

\author{
Timothy K. Perttula and Bo Nelson
}

\section{Introduction}

The Polk Estates site (41CP245) is a prehistoric Caddo archaeological site in the Big Cypress Creek Basin, located just downstream of the confluence of Walkers Creek with Big Cypress Creek. This area is within the Pineywoods of northeastern Texas. It was also occupied in Woodland (ca. 500 B.C. to A.D. 800) and Late Archaic (ca. 2500-500 B.C.) periods, based on the recovery of temporally diagnostic dart points dating to these periods.

The site is on a natural rise (300-310 feet amsl) atop an upland inter-stream divide, less than $300 \mathrm{~m}$ west from the current channel of Big Cypress Creek. The rise has deep Bowie fine sandy loam sediments, with 0-3\% slopes (Roberts 1990:23). It covers about 4100 square meters ( 1.0 acres) in size.

The Polk Estates site is just downstream from the large Titus phase (ca. A.D. 1430-1600) community at the Pilgrim's Pride site (Perttula 2005, ed.). The Titus phase mound site-41CP246 (the Tiddle Lake site)-lies in the Big Cypress Creek floodplain just to the east of the Polk Estates site (see Appendix 5, this volume). What drew our attention to the Polk Estates site was the reported looting and uncontrolled excavations of the site and of Titus phase Caddo burials from the site, as we have been involved for some years in documenting the looting of Caddo cemeteries (see Nelson and Perttula; Perttula and Nelson 1999).

When Bo Nelson first visited the site area in the mid-1980s, he noted a large number of recently excavated holes, many of them grave-sized, across the top of the natural rise (Figure 1). He reported this to the current landowner, Mr. John Polk. Mr. Polk confiscated several vessels from these individuals, including Ripley Engraved vessels and several medium-sized brushed utility ware jars. Mr. Polk also refused these individuals permission to come on the property.

In 1999, Scott Polk, son of Mr. John Polk, contacted Nelson because looting at the site had started again; the looters were apparently from the Longview, Texas area. Scott Polk asked Nelson what could be done to stop this new round of looting, which was when we became involved in investigating the site. Because of the increased attention the site was now receiving from the landowner, the Longview looters stopped going to the site.

From discussions with local collectors and diggers, Nelson was able to learn that between 20-30 burials with Titus phase ceramic vessels had been dug at the site over the last few years (Perttula 2005, ed.: Table 11-4). He also learned that Mr. Trammell Crow (from Dallas, Texas) and associates had also dug at the site a few years ago, sometime 
after 1999 (these are labeled holes 2, 5, 27-30, and 32 on Figure 1). These uncontrolled excavations resulted in the recovery of an unknown number of artifacts, which were divided between the individuals participating in the uncontrolled excavations, but we have not had an opportunity to examine them yet.

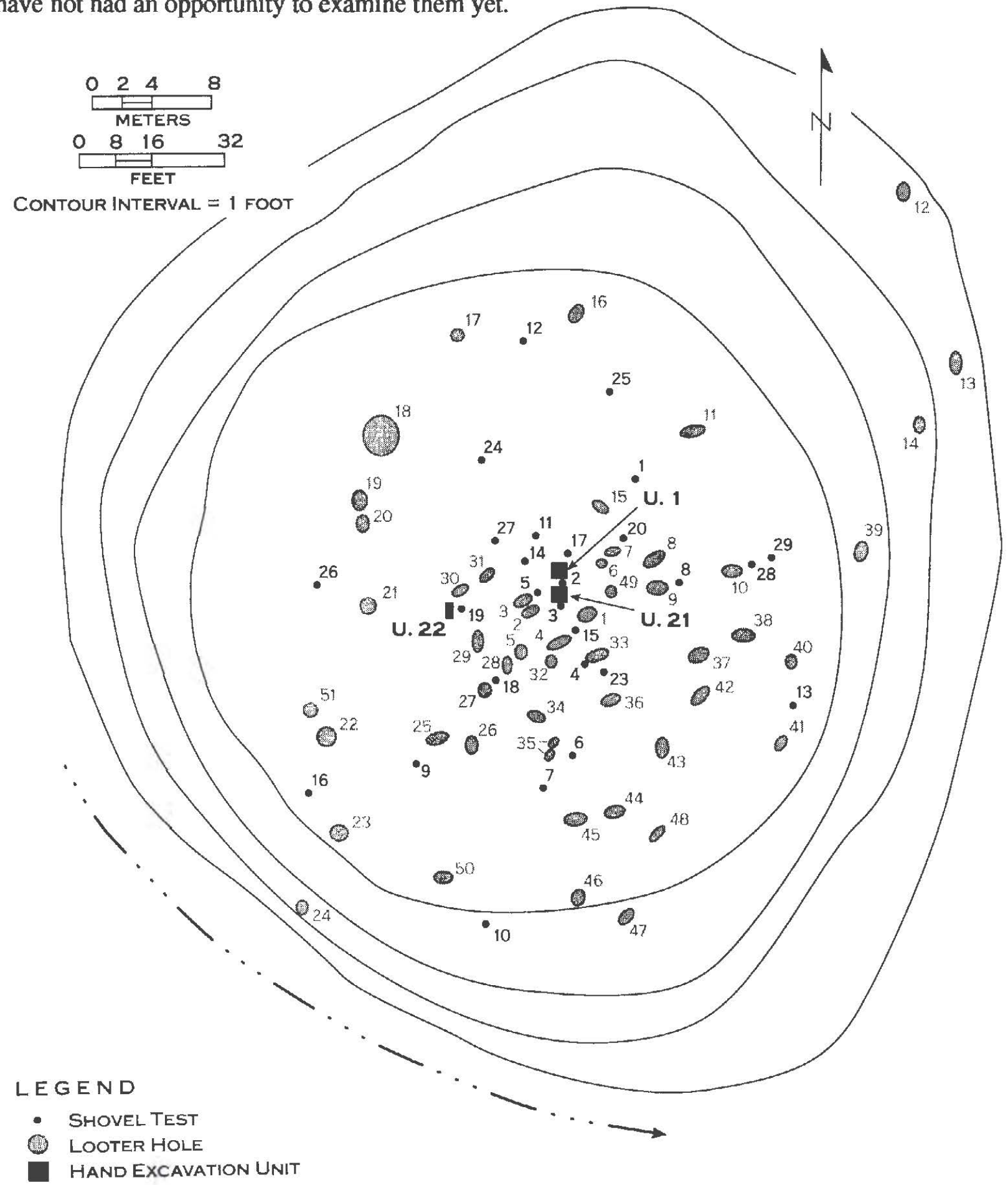

Figure 1. Map of the Polk Estates site, showing the location of shovel tests, handexcavated units, and looter holes. 
A few shovel tests excavated at that time by Nelson and Bobby Gonzalez documented the fact that there were extensive archeological deposits at the Polk Estates site that did not appear to be related to the Titus phase cemetery marked by the many irregular-shaped holes visible on the rise. We first mapped the visible holes (see Figure 1 ), after we used rakes to remove the thick leaf litter across the majority of the rise. A total of 21 of these have the right shape, depth, and orientation to be from the looter excavation of burial pits, while the others are probably exploratory looter holes whose purpose was to attempt to locate burial pits or other features of interest to the looters. The probable burial pits include looter holes $1-4,7-15,19,33,36-38,42,44-45$, and 50 (see Figure 1). These burial pits are concentrated on the central part or crest of the rise, as well as along the southern part of the rise.

During visits to the site in the fall of 1999 , the spring of 2000 , and the fall of 2000 , we excavated a few more shovel tests across the rise to get a better idea of the archeological character (i.e., depth and contents) of the deposits on the rise. During the course of the field work, we excavated $21 \times 1 \mathrm{~m}$ units (unit 1 and 21) and a $1 \times 0.5 \mathrm{~m}$ unit (Unit 22) on the rise, as well as 27 shovel tests (see Figure 1). From this work, we documented that there are extensive archeological deposits (see Appendix 6, this report) of prehistoric Caddo. Woodland, and Late Archaic age on the natural rise, and these deposits are more than $130 \mathrm{~cm}$ in thickness.

\section{Archeological Deposits and Work Conducted}

During the shovel testing, we identified a thick midden deposit in the upper $45 \mathrm{~cm}$ of the archeological deposit. These midden deposits are confined to the central part of the natural rise (Figure 2).

The midden deposits in Unit 1 (Zones $A$ and B) are about $60 \mathrm{~cm}$ thick, and these are a dark brown sandy loam (Figure 3). Below the midden is a $30 \mathrm{~cm}$ thick grayishbrown sandy loam E-horizon (Zone $\mathrm{C}$ ), atop a light grayish-brown sandy loam zone (Zone D) that is at least ca. $12-13 \mathrm{~cm}$ thick. Below this are yellowish-brown and light yellowish-brown E-horizon sandy loam zones separated by $2-5 \mathrm{~cm}$ thick clay lamella. Below the second lamella (ca. $135-138 \mathrm{~cm}$ bs) is a dark yellowish-brown sandy loam zone )Zone F) about $25 \mathrm{~cm}$ in thickness. The third and deepest exposed lamella lies approximately $160 \mathrm{~cm}$ bs (see Figure 3 ).

The midden deposits in Unit 21 are about $48 \mathrm{~cm}$ in thickness. In Unit 22, the midden deposits are $45 \mathrm{~cm}$ thick $(0-45 \mathrm{~cm})$, and consist of a compact (at least to $38 \mathrm{~cm}$ bs) very dark gray (10YR 3/1) sandy loam. These deposits overlie a very dark grayishbrown (10YR 3/2), dark brown (10YR 3/3), to brown (10YR 4/3) sandy loam E-horizon sediments from $45-70 \mathrm{~cm}$. 


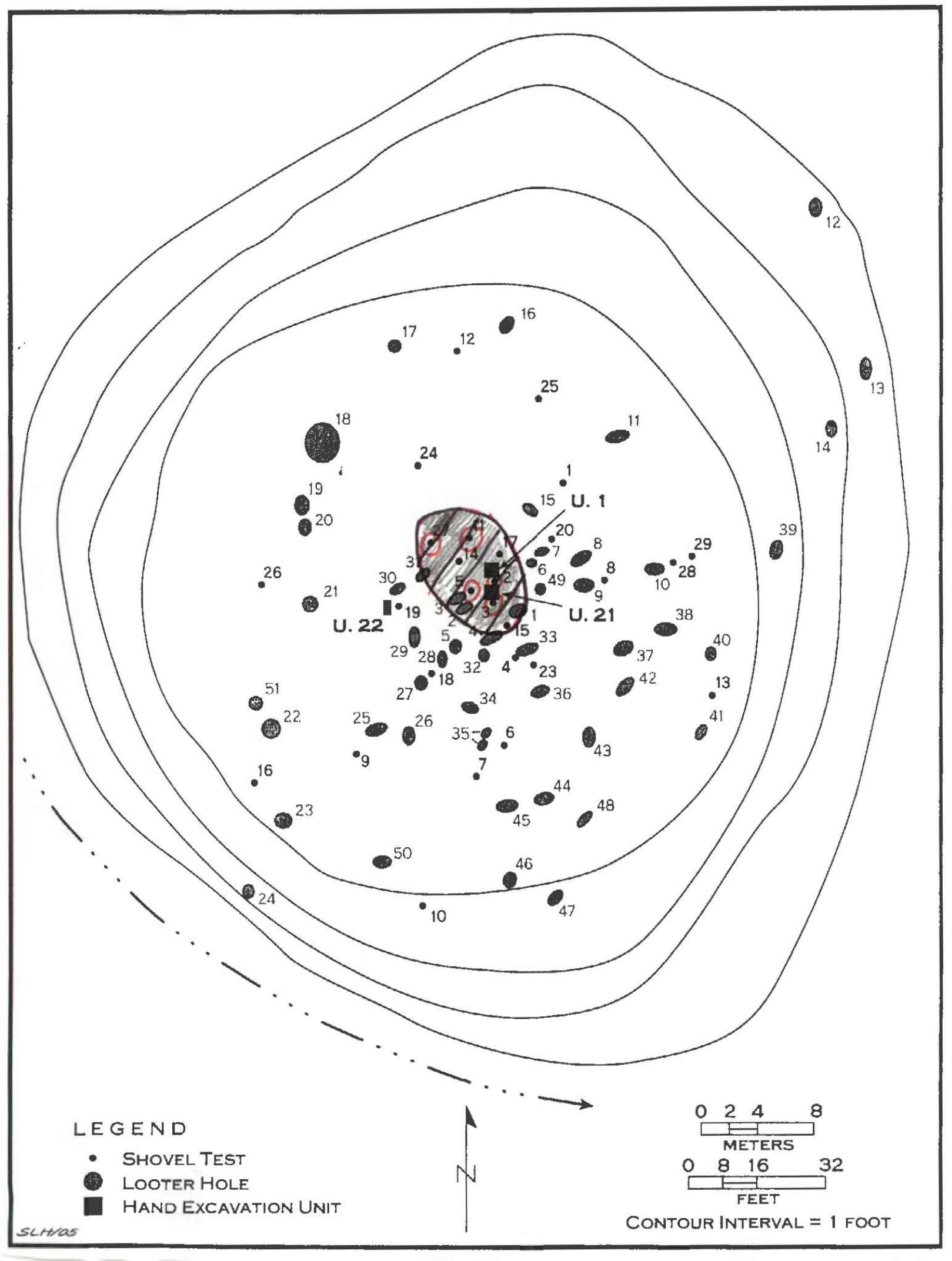

Figure 2. Extent of midden deposits documented at the Polk Estates site. 


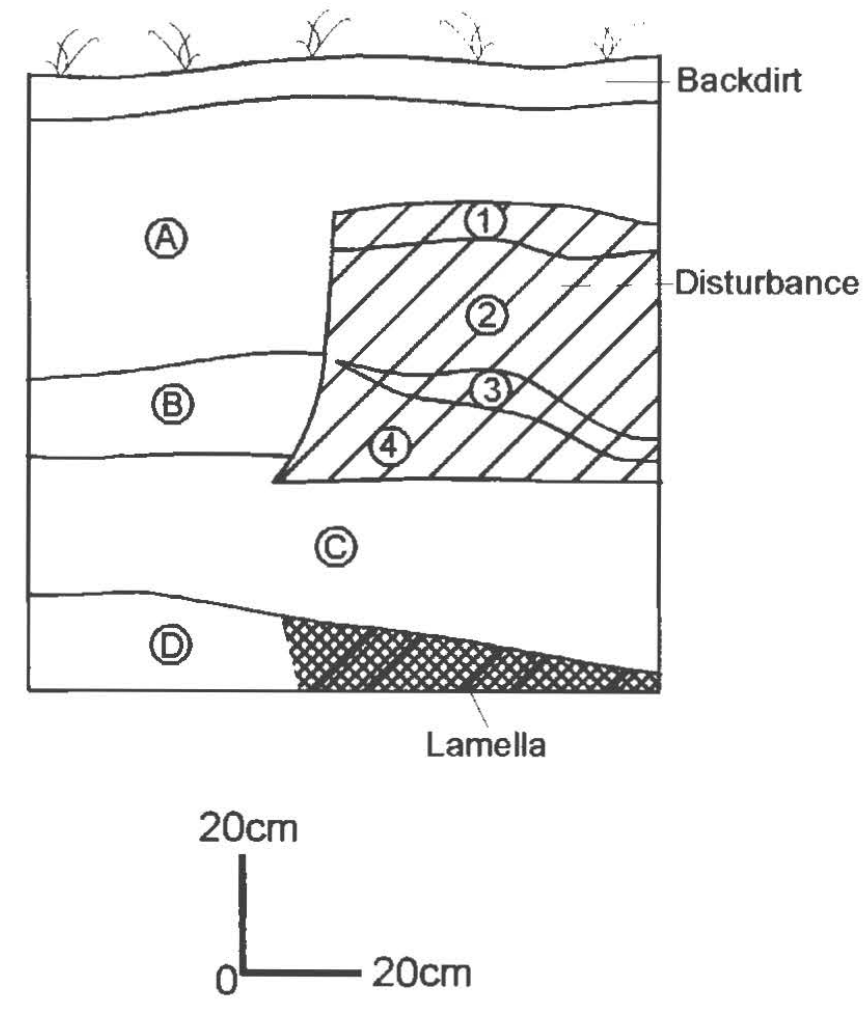

Figure 3. Profile of Unit $I$ at the Polk Estates site.

The northern and eastern half of Unit 1 had been previously disturbed by looters. This disturbance began about $20 \mathrm{~cm}$ bs, and extended to approximately $65 \mathrm{~cm}$ bs (see Figure 3). Five small probe holes were also visible in the northwestern quadrant of the unit in the $10-20 \mathrm{~cm}$ bs level; these had become filled with a light brown soil. 


\section{Radiocarbon and OCR Dates}

Radiocarbon samples of charred hickory (Carya sp.) nutshells and unburned animal bone were submitted to Beta Analytic Inc. for radiocarbon dating. The radiocarbon data forms are provided in Appendix 4 of this report.

The one sample of large mammal (i.e., deer) animal bone $(53.5 \mathrm{~g})$ submitted for dating came from Unit 1, 30-50 cm bs. The other three samples (all of hickory nutshell) came from different depths in Unit $21: 60 \mathrm{~cm}$ bs $(0.2 \mathrm{~g}) ; 70-80 \mathrm{~cm}$ bs $(0.1 \mathrm{~g})$; and $80-100$ $\mathrm{cm}(2.1 \mathrm{~g})$.

Although only four dates were obtained, they indicate that the archaeological deposits are stratified, and range (at least in the upper $100 \mathrm{~cm}$ of the deposits) in age from A.D. 250 to A.D. 1420: the Woodland, early Caddo and middle Caddo periods.

The youngest date (Beta-208772), cal AD 1300-1420 (2 sigma) has a calibrated intercept of A.D. 1400. Corresponding OCR dates from the midden zone in which the animal bone sample came from $(30-50 \mathrm{~cm}$ bs) range from ca. A.D. $1360-1400$. The next range of dates come from nutshell recovered between $60-80 \mathrm{~cm}$, and these are AD 9801150 (2 sigma and a calibrated intercept of A.D. 1020, Beta-208774) and AD 660-860 (2 sigma and a calibrated intercept of A.D. 710, Beta-208773), suggesting an Early Caddoan period age for the second cultural zone. The earlier date is from $70-80 \mathrm{~cm}$ bs, while the later date is from $60 \mathrm{~cm}$ bs.

The oldest radiocarbon date is A.D. 250-430 (Beta-208775, 2 sigma and with a calibrated intercept of A.D. 380) from the deeper archaeological deposits $(80-100 \mathrm{~cm})$. The OCR dates (see below) from the ca. $90-135 \mathrm{~cm}$ depth also indicate that there were preserved Woodland period (i.e., 500 B.C.-A.D. 800) archaeological deposits at the Polk Estates site.

A total of 31 Oxidizable Carbon Ratio (OCR) sediment samples (ca. 200 grams each) were taken at $5 \mathrm{~cm}$ intervals from the profile of the Unit 1 excavations. The samples ranged in depth from 10 to $160 \mathrm{~cm}$ bs (Figure 4).

The OCR dates (see Appendix 3) strongly suggest that the upper $45 \mathrm{~cm}$ of the archaeological deposits - basically a midden zone - ranges in age from ca. A.D. 13601410. Below this, a second cultural zone (also in the midden) identified in the OCR samples is estimated to date from ca. A.D. 1160-1180, with an average age of A.D. 1183. The third possible occupation (ca. $70-85 \mathrm{~cm}$ bs) has an average OCR age of A.D. 840850 (see Figure 4).

Douglas Frink (June 24, 2000 e-mail communication to the senior author) also suggests that based on chemical and physical textural differences in the sediments that there may also be human-related occupations more deeply buried (i.e., below the depth of the obtained radiocarbon dates) in the Polk Estates archeological deposits. These are in the $120-125 \mathrm{~cm}$ samples (dating from ca. A.D. 270-500) and the $135-145 \mathrm{~cm}$ samples 
(dating from ca. 1840-1190 B.C.). If accurate, these OCR dates suggest that there are preserved Woodland and Late Archaic period occupational deposits buried beneath the Caddo occupational zones.

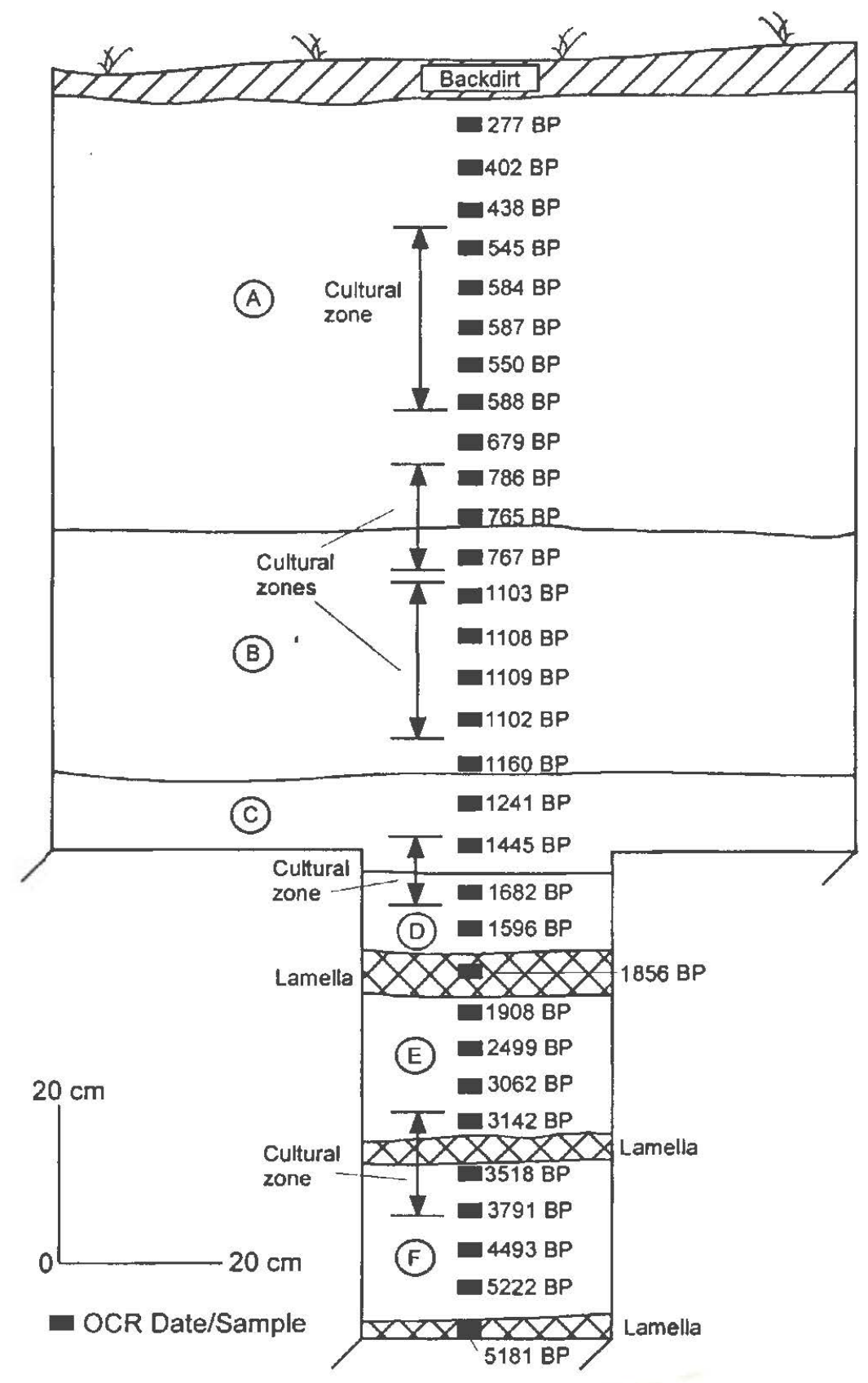

Figure 4. Unit 1 profile with OCR samples and estimated OCR ages. 
There is good concordance between the OCR and calibrated radiocarbon age ranges obtained from the thick archaeological deposits at the Polk Estates site. The deposits between 0-60 cm bs have OCR dates that range from A.D. 1185-1673, with one radiocarbon sample with a calibrated intercept of A.D. 1400, and an age range of A.D. 1300-1420. Taken together, they suggest that the upper deposits date after A.D. 1185 and certainly lasted until A.D. 1420. These deposits may be considered to relate to a Middle Caddo period occupation, of which there are not that many known in the immediate visinity of the Polk Estates site.

A second Caddo occupation appears to be present between $60-90 \mathrm{~cm}$ bs, in the lower part of the midden deposits. The OCR dates range from A.D. 790-1183 at these depths, and the calibrated intercepts of the two radiocarbon dates from these deposits are A.D. 710 and A.D. 1020. These deposits would seem to be of early Caddo age, ranging from about A.D. 800-1220.

The deeper Woodland and Late Archaic archaeological deposits are in the 90-160 $\mathrm{cm}$ depths in the excavated area at the Polk Estates site. The one radiocarbon date near the top of these deposits has a A.D. 380 calibrated intercept. The OCR dates from the same depths as the radiocarbon sample of nutshells range from A.D. 505-848. Together, they indicate a Woodland period occupation is present in at least the upper (ca. 90-135 $\mathrm{cm}$ bs) part of these archaeological deposits. Unfortunately, we were not able to obtain a radiocarbon date from the lowest part of the archaeological deposits (i.e., $135-160 \mathrm{~cm}$ bs), so we cannot confidentially identify them as being Late Archaic in age. However, the OCR dates from these lower deposits range from 3518-5222 B.P., consistent with the postulated Late Archaic age

\section{Stable Isotope Analysis}

During the investigations, a small amount of unidentifiable human remains were recovered from ST 19, 70-80 cm bs, in what appeared to be Early Caddoan period (ca. A.D. 900-1200) archeological deposits (see discussion of radiocarbon and OCR dates, above) at the Polk Estates site. We submitted these remains to Beta Analytic, Inc. for dating and stable isotope analysis, but the sample did not contain sufficient intact and preserved collagen to obtain a reliable radiocarbon date from these remains. We did, however, obtain information on the stable carbon isotope (C13/C12) value of these particular remains, which was $-21.2 \mathrm{o} / \mathrm{oo}$ (see Appendix 4). This low value suggests that this individual in Early Caddoan period times did not consume much maize in its diet. Later Titus phase burials and other post-A.D. 1400 Caddo burials in the region have higher (more negative) stable carbon isotope values between $-16 \mathrm{o} / 00$ and $-14 \mathrm{o} / 00$ (Perttula 2005: Figure 8). These values suggest that maize comprised at least $50 \%$ of the diet by those times.

\section{Material Culture Remains}

A total of 1710 prehistoric artifacts were recovered during our limited archeological investigations at the Polk Estates site (see Appendix 6). Lithic debris and 
cores - the residue of tool manufacture and resharpening activities carried out at the site-comprise almost $73 \%$ of the artifact assemblage, with ceramic sherds $(n=324)$ accounting for ca. 19\% of the recovered artifacts (Table 1). In Units 1 and 22, the artifact density is more than 300 artifacts per square meter. In some of the shovel tests (i.e., ST 2, 3 , and 23 in the midden), artifact densities ranged between ca. 400-600 artifacts per square meter of archeological deposits.

Table 1. Artifact Inventory by Provenience, the Polk Estates site (41CP245).

\begin{tabular}{|c|c|c|c|c|c|c|c|}
\hline Provenience & PS & DS & $\mathrm{BC} / \mathrm{D}$ & Tools & LD* & FCR & $\mathbf{N}$ \\
\hline LH-3 & 11 & 3 & 4 & 1 & 25 & - & 44 \\
\hline LH-16 & - & 1 & - & - & - & - & 1 \\
\hline LH-4l & - & - & - & - & 3 & - & 3 \\
\hline General Surface & 10 & 5 & - & 1 & 12 & 1 & 29 \\
\hline Midden Surface & - & 1 & - & - & 1 & - & 2 \\
\hline Spoil Pile & - & - & - & 2 & 12 & 2 & 16 \\
\hline ST 1 & 4 & 1 & - & 1 & 17 & - & 23 \\
\hline ST 2 & 9 & 3 & $7 / 1$ & - & 43 & 1 & 64 \\
\hline ST 3 & 6 & 1 & $5 / 1$ & 1 & 37 & 1 & 52 \\
\hline ST 4 & 1 & 1 & $0 / 1$ & 2 & 24 & - & 29 \\
\hline ST 5 & 3 & 8 & $0 / 11$ & 1 & 17 & - & 40 \\
\hline ST 6 & - & - & - & 2 & 27 & - & 29 \\
\hline ST 7 & - & 1 & - & - & 18 & - & 19 \\
\hline ST 8 & 2 & 3 & - & - & 15 & - & 20 \\
\hline ST 9 & 1 & 2 & 1 & 1 & 8 & - & 13 \\
\hline ST 10 & - & 3 & - & - & 7 & - & 10 \\
\hline ST 11 & 1 & 5 & $0 / 1$ & 1 & 28 & - & 36 \\
\hline ST 12 & 1 & - & - & - & 6 & - & 7 \\
\hline ST 13 & 1 & 2 & - & - & 12 & & 15 \\
\hline ST 14 & 4 & - & $3 / 1$ & 1 & 34 & - & 43 \\
\hline ST 15 & 6 & 1 & 2 & 2 & 40 & 1 & 52 \\
\hline ST 16 & 2 & - & - & - & 10 & - & 12 \\
\hline ST 17 & 3 & 2 & 1 & - & 29 & - & 35 \\
\hline ST 18 & 11 & 4 & - & - & 21 & - & 36 \\
\hline ST 19 & 5 & 4 & 1 & - & 17 & - & 27 \\
\hline ST 20 & 4 & 5 & - & - & 30 & - & 39 \\
\hline ST 23 & 1 & 2 & 5 & - & 75 & 1 & 84 \\
\hline ST 24 & - & - & - & - & 9 & - & 9 \\
\hline ST 25 & - & 1 & - & - & 15 & - & 16 \\
\hline ST 26 & 3 & - & - & 1 & 8 & - & 12 \\
\hline ST 27 & 2 & 1 & 2 & 1 & 30 & - & 36 \\
\hline ST 28 & - & 5 & - & - & 18 & 1 & 24 \\
\hline ST 29 & 2 & 1 & 1 & - & 10 & - & 14 \\
\hline
\end{tabular}


Table 1. Artifact Inventory by Provenience, the Polk Estates site (41CP245), cont.

\begin{tabular}{llllllll}
\hline Provenience & PS & DS & BC/D & Tools & LD* & FCR & N \\
\hline Unit 1 & 28 & 22 & 8 & 4 & 237 & 1 & 300 \\
Unit 21 & 49 & 18 & $11 * *$ & 17 & 251 & 4 & 350 \\
Unit 21, FS & 3 & - & 9 & - & 33 & 3 & 48 \\
Unit 22 & 9 & 10 & $5 / 2$ & 2 & 27 & - & 55 \\
Unit 22/22A & 2 & 3 & - & - & 10 & - & 15 \\
Unit 22A & 13 & 8 & 1 & 2 & 37 & - & 61 \\
\hline & 197 & 127 & $66 / 18$ & 43 & 1243 & 16 & 1710 \\
Totals & & & & & \\
\hline *includes cores; ** includes 1 clay coil; PS=plain sherds; DS=decorated sherds; \\
BC/D=burned clay/daub; LD=lithic debris; FCR=fire-cracked rock
\end{tabular}

\section{Ceramic Sherds}

Ceramic sherds are abundant in the archeological deposits across the rise at the Polk Estates site, and we recovered 324 sherds during our limited work. In the hand-excavated units, sherd densities range from 50-95 sherds per square meter, with the highest densities in Units 21 and 22 (see Table 1). Shovel tests with the highest sherd densities are ST 18 (ca. 120 per square meter), ST 2 (ca. 96 sherds per square meter), ST 5 (ca. 88 sherds per square meter), and ST 15 (ca. 56 sherds per square meter) on the central part of the natural rise (Figure 5). By depth, the highest densities of sherds in the controlled excavations are between $40-70 \mathrm{~cm}$ bs $(46 \%$ of the sherds) as well as $10-20 \mathrm{~cm}$ bs $(11.5 \%)$ in what apparently are the Middle Caddo occupational component. In the shovel tests, most of the sherds (43\%) came from $20-40 \mathrm{~cm}$ bs, followed by the $0-20 \mathrm{~cm}(15.4 \%)$ and $40-60 \mathrm{~cm}(15.4 \%)$ levels.

The plain-to-decorated sherd ratio (P/DR) for the assemblage is 1.55. This is comparable to that documented to date from Middle Caddoan period (ca. A.D. 1200-1400) ceramic assemblages in the larger northeastern Texas region (especially prehistoric Caddo sites in the Neches, Angelina, and Sabine River basins), where P/DR of 1.30-2.65 have been documented, although the Polk Estates site does not appear to have been occupied by prehistoric Caddo peoples only in this period of time (based on the age of the looted burials and some suggestion of a pre-A.D. 1200 Caddo component).

In looking at the vertical differences in the sherds from the hand-excavated units, the uppermost and latest Caddo deposit at the site $(0-50 \mathrm{~cm})$ the P/DR is only 1.56 compared to $1.89 \mathrm{P} / \mathrm{DR}$ in the lowermost Caddo component $(50-90 \mathrm{~cm} \mathrm{bs})$. As another indication of a chronological difference in the Caddo ceramics in the archaeological deposits, $37.5 \%$ of all 
the decorated sherds in the latest Caddo occupation is brushed, but only $25 \%$ are brushed in the lower and earlier Caddo occupation at the Polk Estates site.

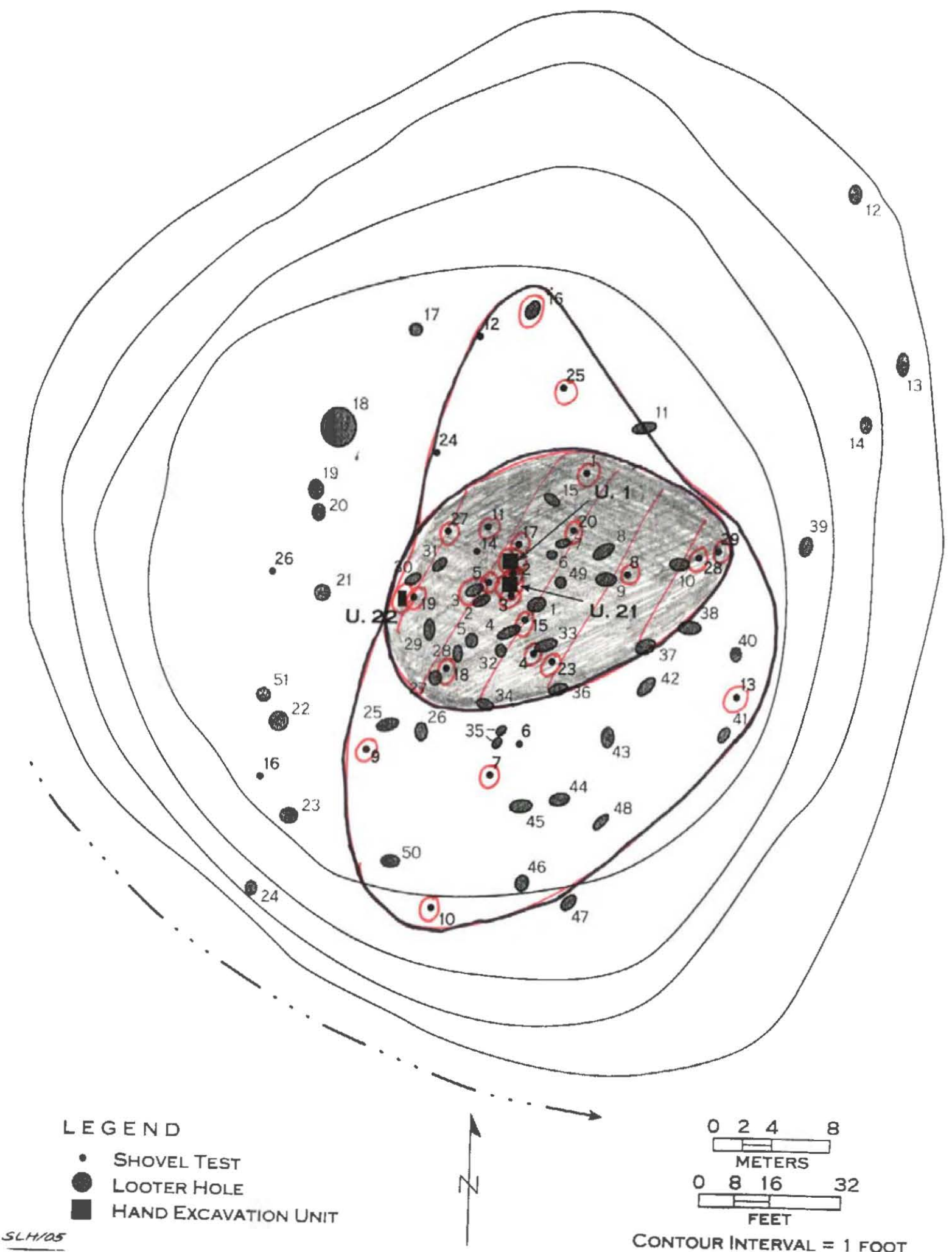

Figure 5. Distribution of decorated sherds at the Polk Estates site. 
The ceramic sherds are from fine ware and utility ware vessels that had been tempered with both grog and burned bone, and the vessels had predominately been fired in a low oxygen or reducing environment and cooled in the open air. The vessels that were produced were sturdy and durable, and probably could have been used for several years by individual families of Caddo people that lived at the site.

The decorated fine wares (i.e., engraved and red-slipped sherds) comprise $36.6 \%$ of the decorated sherd assemblage (Table 2), with the remainder of the decorated sherds being from coarse-tempered utility wares with wet-clay decorations (i.e., brushed, incised, punctated vessel sherds). Among the rims $(\mathrm{n}=19)$, almost $74 \%$ of the sherds are from utility wares.

Table 2. Decorated Sherds from the Polk Estates site.

Decorative Method/ Rim $\quad$ Body
Element

Fine wares

Exterior red-slipped

Horizontal engraved

Interior/exterior red-slipped

Engraved triangles

Parallel engraved

Single straight engraved line

Diagonal engraved

Curvilinear engraved

Zoned hatched engraved

Red-slipped and noded

Spiro/Holly Engraved

Parallel-diagonal engraved

Circular engraved

$\begin{array}{lll}- & 12 & 12 \\ 2 & 4 & 6 \\ - & 4 & 4 \\ 1 & 3 & 4 \\ - & 4 & 4 \\ - & 4 & 4 \\ 2 & 1 & 3 \\ - & 2 & 2 \\ - & 2 & 2 \\ - & 1 & 1 \\ - & 1 & 1 \\ - & 1 & 1 \\ - & 1 & 1\end{array}$

Utility wares

Parallel brushed

Parallel Incised

Tool punctated

Diagonal incised

Incised-zoned punctated

Horizontal brushed-tool punctated

Appliqued

Opposed incised

Parallel brushed-incised

Horizontal brushed

Diagonal brushed-tool punctated

-
-
2
4
2
2
1
-
-
1
1

25

14

9

5

3

3

2

2

2

1

1 
Table 2. Decorated Sherds from the Polk Estates site, cont.

\begin{tabular}{llll}
\hline $\begin{array}{l}\text { Decorative Method/ } \\
\text { Element }\end{array}$ & Rim & Body & N \\
\hline $\begin{array}{l}\text { Parallel brushed-incised/appliqued } \\
\text { Parallel brushed-incised/tool } \\
\quad \text { punctated }\end{array}$ & - & 1 & 1 \\
Parallel-diagonal incised & - & 1 & 1 \\
Incised-appliqued & - & 1 & 1 \\
Cross-hatched incised & - & 1 & 1 \\
Rectilinear incised & - & 1 & 1 \\
Noded & - & 1 & 1 \\
Fingernail punctated & - & 1 & 1 \\
Cane punctated & 1 & - & 1 \\
Punctated & - & 1 & 1 \\
Single straight incised line & - & 1 & \\
& & & \\
\hline
\end{tabular}

Among the fine ware sherds, the single most common decoration is red-slipping (see Table 2). There are 16 body sherds with red-slipping either on the interior and/or exterior surfaces, which comprises $35 \%$ of the fine wares. These sherds are most likely from red-slipped bowls, carinated bowls (see Figure 11e), and bottles. One another redslipped sherd is from a bottle that has a set of nodes on the exterior body surface. Although rarely found, this particular sherd (see Figure 11b) is probably from a Maxey Noded Redware bottle (Suhm and Jelks 1962: Plate 51).

The engraved sherds are dominated by sherds with sets of horizontal lines around the rim of bottles (Figure $6 c$ ) and bowls/carinated bowls (Figure 7b). This includes two rim sherds (see Table 2). Parallel engraved sherds $(n=4)$ (see Figure $7 a$ ) are probably also from fine ware vessels decorated with sets of horizontal engraved lines. 


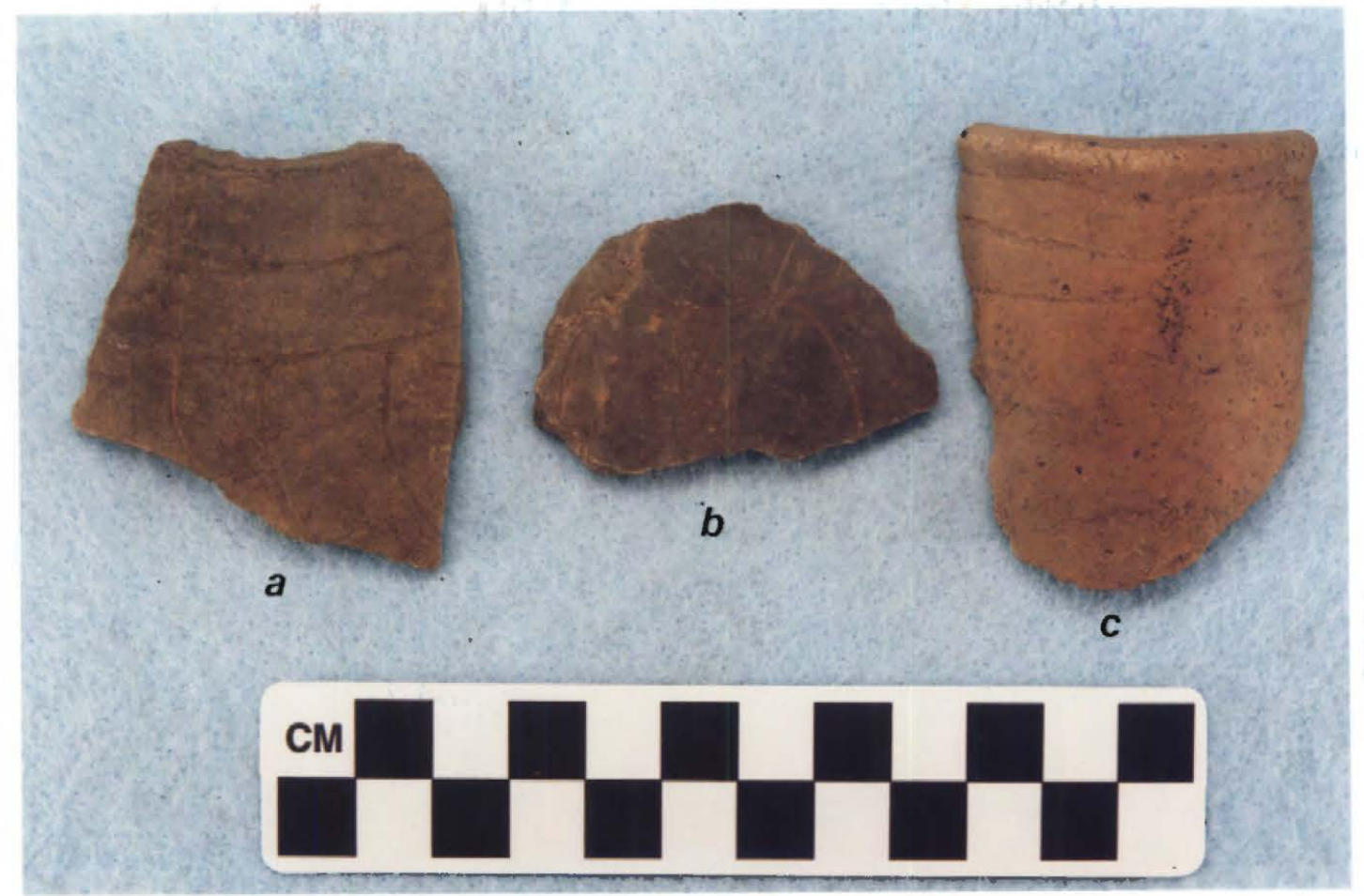

Figure 6. Engraved bottle sherds. Provenience: a-b, ST 28, 20-40 cm; c, Looter Hole 16, surface.

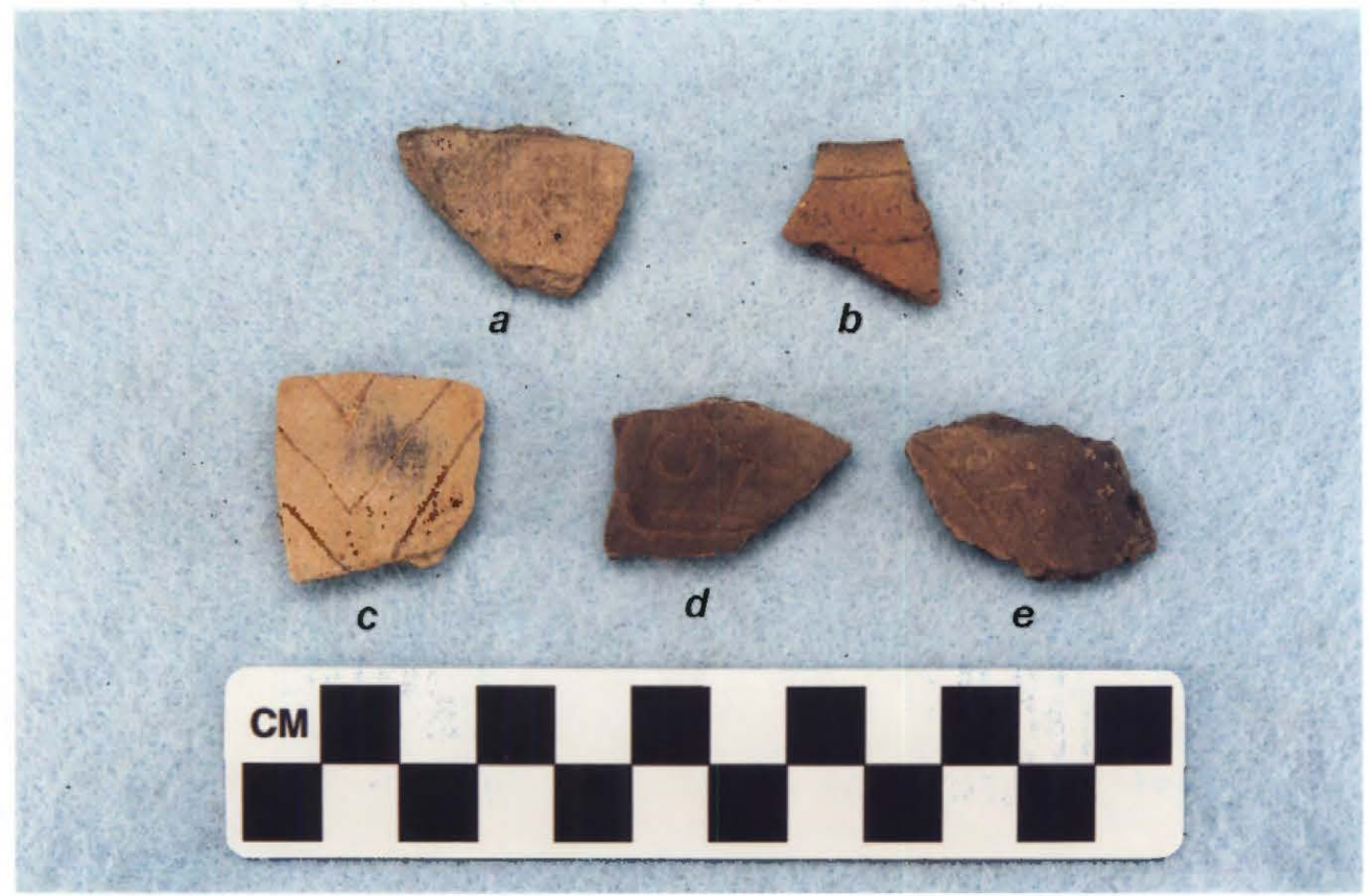

Figure 7. Engraved bowl and carinated bowl sherds. Provenience: a, Unit 22/22A, $60-70 \mathrm{~cm}$; b, ST 25, 10-20 cm; c, ST 19, 70-80 cm; d, ST 28, 0-20 cm; e, Unit 21, 40-50 cm. 
Three sherds have large engraved triangles that are pendant from a horizontal engraved lines (see Figure 9e), while two others have zoned hatched areas (see Figure 7e). One bottle sherd has a combination of parallel engraved lines (encircling the bottle neck) with diagonal engraved lines extending down the vessel body (see Figure 6a), while another has a zone of hatching between single horizontal and vertical lines (see Figure 6b). The most distinctive engraved sherd from the Polk Estates site is a Spiro Engraved body sherd, probably from a jar or beaker form (cf. Suhm and Jelks 1962: Plate 74i) with a series of opposed lines and a nested area of excision (see Figure 7c). This particular sherd was found in ST 19 between 70$80 \mathrm{~cm}$ bs in an apparent Early Caddo context.

Other engraved elements include sherds with sets of curvilinear lines $(n=2)$, diagonal lines on the rim $(n=3)$, and sherds with a single straight engraved line $(n=4)$. One sherd has a circular motif (see Figure 7d).

Among the utility wares, sherds with some form of brushing (by itself, or in association with other decorative elements) are the most common at the Polk Estates site. Sherds with brushing comprise almost $43 \%$ of the utility wares, and about $29 \%$ of the utility ware rim sherds. Other common decorative methods in the utility wares at the site are incised, tool punctations, and zoned incised-punctated (see Table 2).

Most of the brushed sherds have parallel (probably oriented vertically on the vessel body) brushing marks (Figure $8 \mathrm{~b}-\mathrm{d}$ ), but in one case the brushing marks overlap (Figure 8a), or occur in combinatiion with sloppily executed incised lines, punctated rows, or appliqued fillets that parallel the brushing marks. These latter are probably from Pease Brushed-Incised jars.

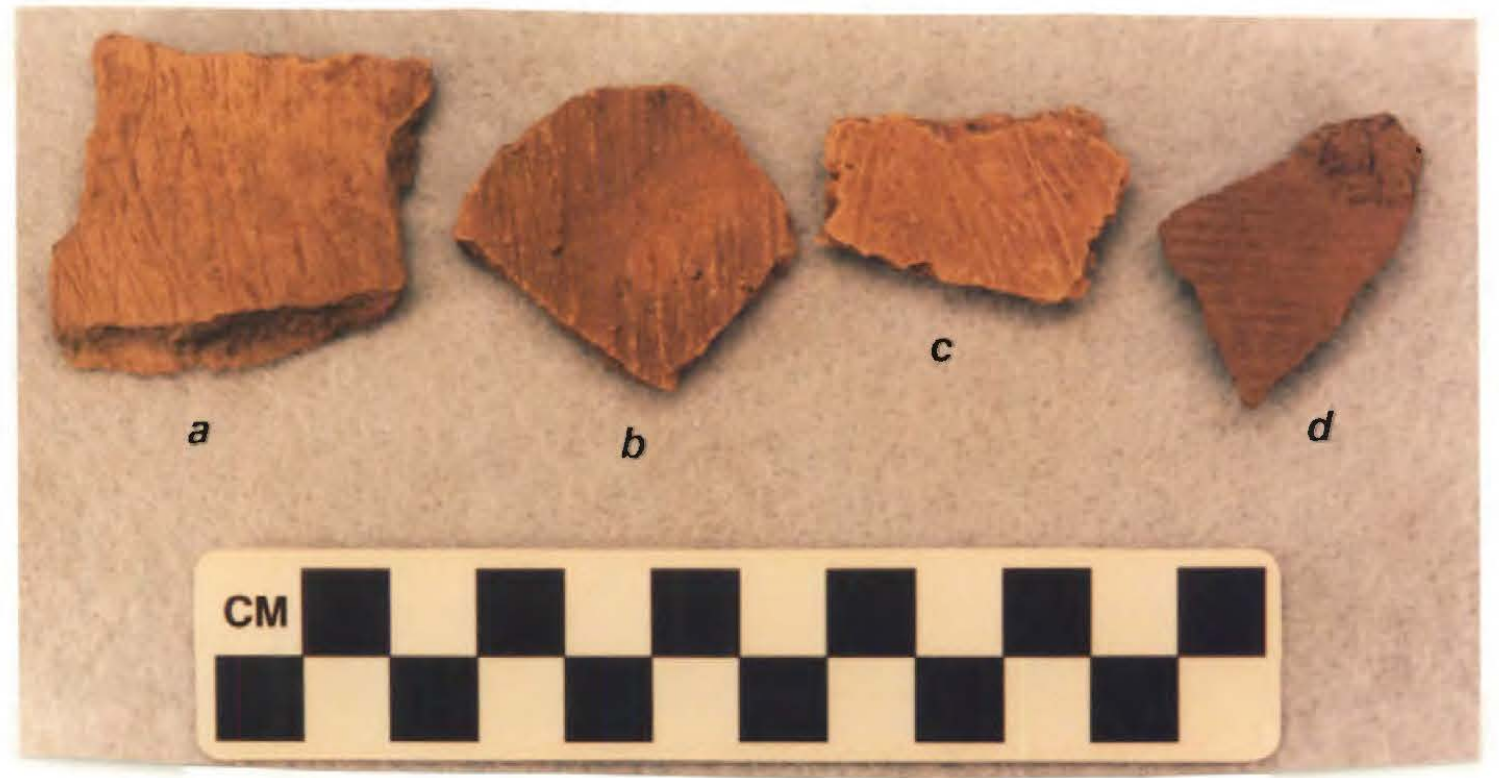

Figure 8. Brushed body sherds. Provenience: a, Unit 22/22A, 50-60 cm; b, Surface; c, ST 5, $20-40 \mathrm{~cm}$; d, Unit $21,60-70 \mathrm{~cm}$. 
Other vessels have horizontal brushing marks on the rim, either decorated solely with brushing (Figure 9c), or the brushing occurs in combination with punctated rows below the lip and/or at the rim-body juncture (Figure 10e-f).

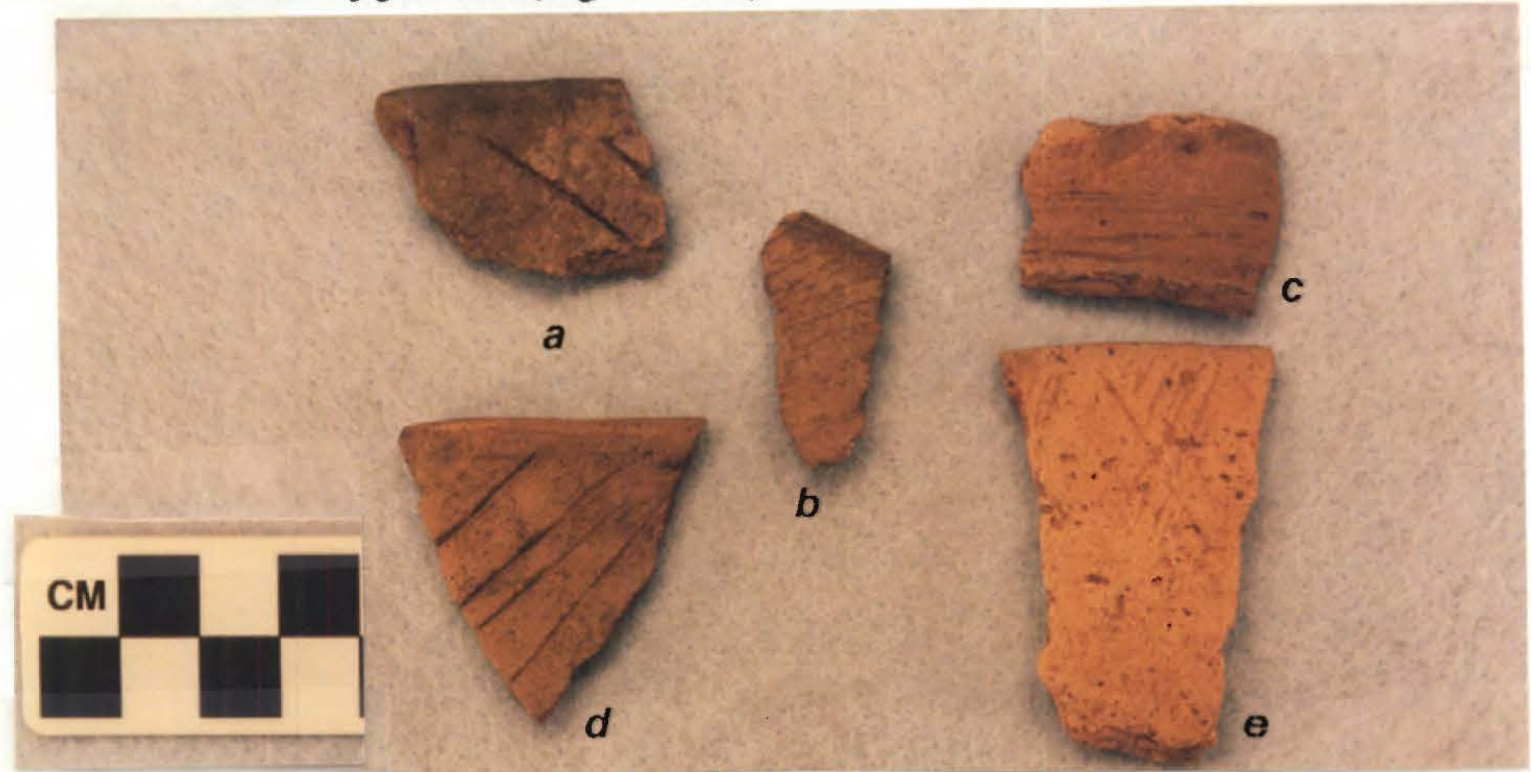

Figure 9. Incised and Brushed Sherds, and an Engraved Rim. Provenience: a, Unit 21, 60-70 cm; b, Surface; c, ST 20, 50-60 cm; d, ST 23, 30-40 cm; e, Unit 1, 10-20 cm.

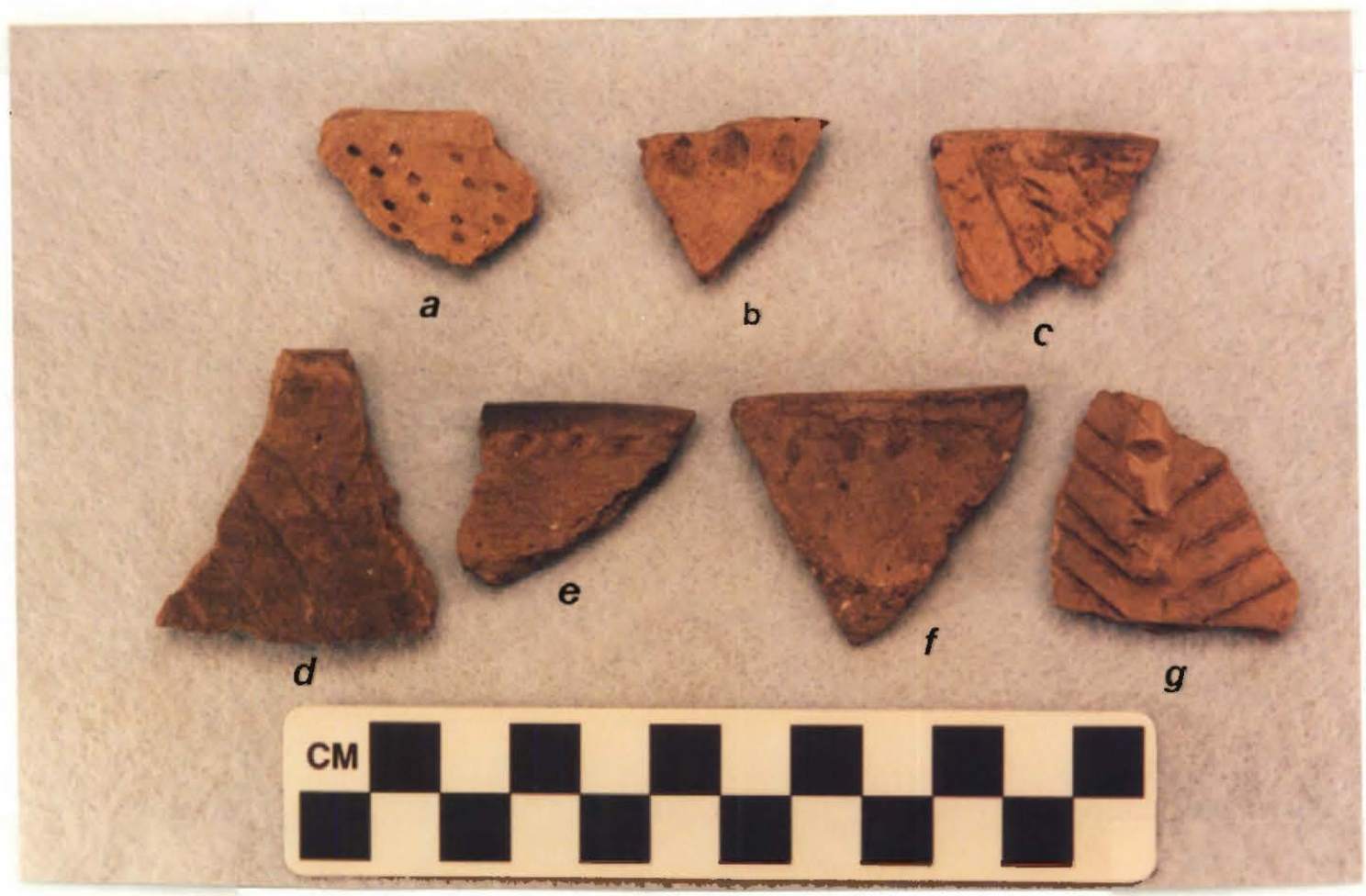

Figure 10. Decorated Utility Wares from the Polk Estates site. Provenience: a, Unit 21, 50-60 cm; b, Unit 21, 40-50 cm; c, ST 1, 80-100 cm; d, Unit 21, 90-100 cm; e, Unit 22, 50-60 cm; f, Unit 1, 20-30 cm; g, Unit 21, 70-80 cm. 
The remainder of the utility wares from the Polk Estates site are comprised principally of sherds from vessels decorated with incised lines or punctations, or vessels with a combination of both decortative methods (see Table 2). The most common incised decoration on the sherds is parallel incised lines ( $n=14)$, diagonal incised on the rim (see Figure 9a-b, d), opposed incised, and cross-hatched incised elements. One body sherd with opposed incised lines also has an appliqued fillet that divided the incised decorative element (see Figure 10g).

There are also incised-punctated sherds in the Polk Estates ceramic assemblage. These have diagonal and triangular incised zones filled with tool and cane punctations (see Figure $10 \mathrm{c}$-d). Other sherds have either tool, fingernail, or cane punctations on the rim and/or body of utility ware vessels. These decorations typically consist of rows of punctations on the vessel rim (see Figure 10a) and rim-body juncture (see Figure 10b), and as free punctated elements covering most of the vessel body. Tool punctations are much more commonly used as a decorative method than either fingernails or cut cane (see Table 2).

The rarer decorated utility wares include sherds from vessels with appliqued ridges and fillets, or with nodes (Figure 11a).

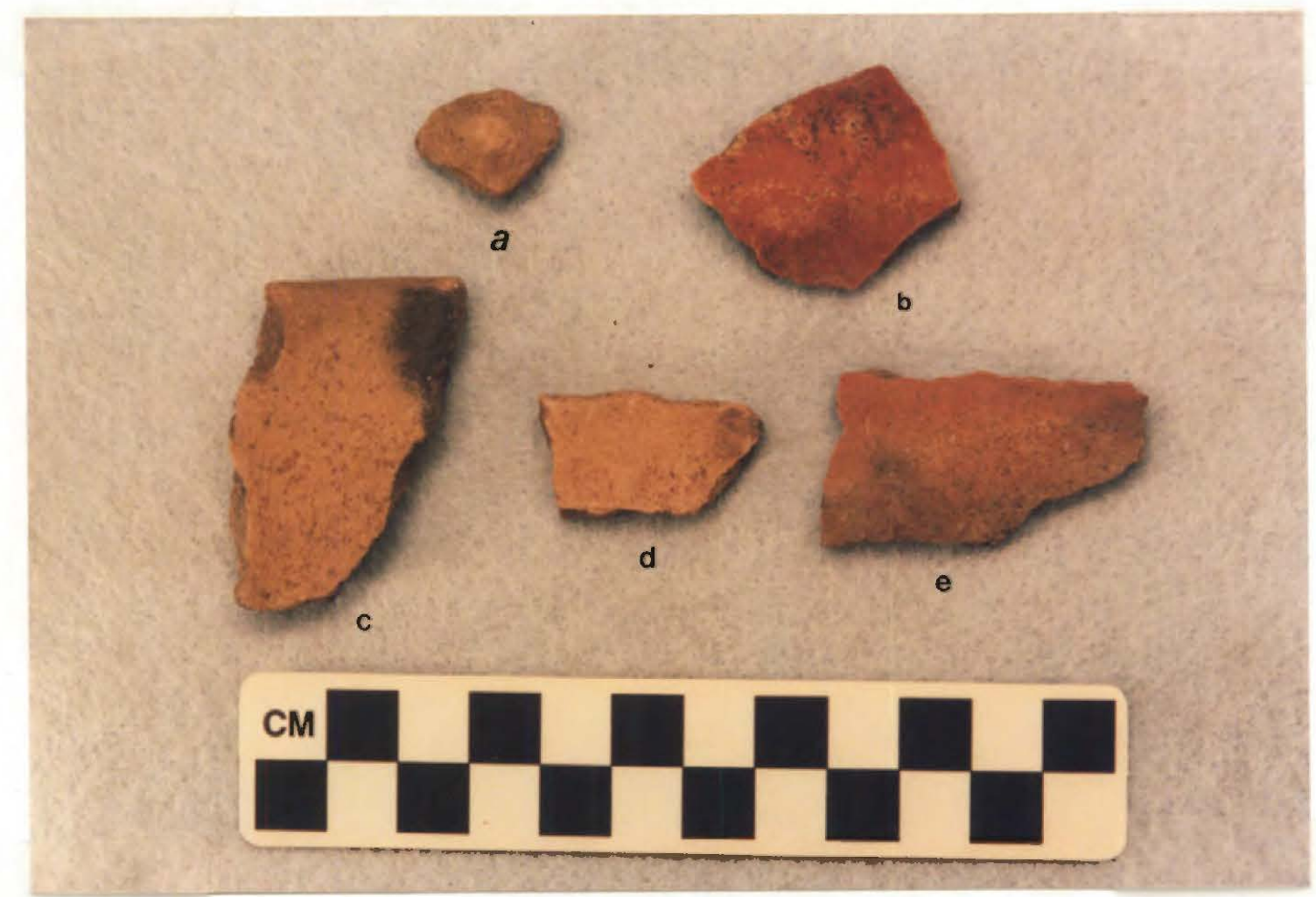

Figure 11. Noded, plain rims, and red-slipped sherds. Provenience: a, Surface; b, ST 18, 50-60 cm; c, Unit 1, 50-60 cm; d, Unit 22A, 0-10 cm; e, Unit 1, 60-70 cm.

Plain rims in the ceramic assemblage have direct rims and rounded to flat lips (see Figure 11c). One rim has a scalloped lip (see Figure 11d), and this is probably from a plain bowl or plain carinated bowl. 


\section{Burned Clay and Daub}

A total of 66 pieces of burned clay and 18 pieces of daub were recovered from the archeological deposits. These pieces came from excavations in the central part of the natural rise (Figure 12), suggesting that a clay and thatch-covered structure may have stood in this area. The overall low density of daub also suggests that no clay and thatchcovered Caddo structure burned down at the Polk Estates site; otherwise, there would be more daub present in the archeological deposits.

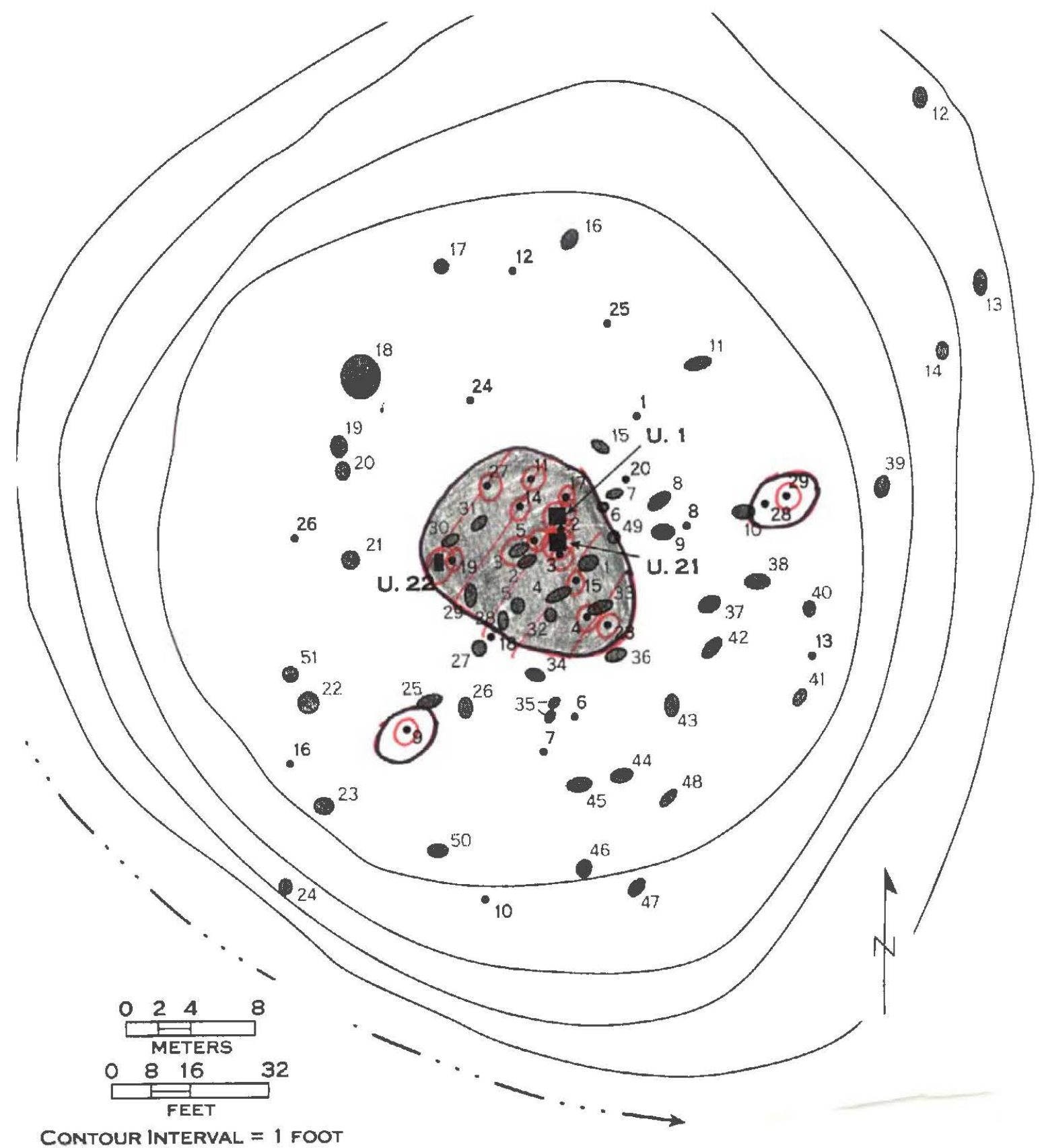

Figure 12. Distribution of daub and burned clay on the Polk Estates site. 
By depth, $90 \%$ of the daub is from $0-40 \mathrm{~cm}$ bs, which has been identified as the Middle Caddo deposits, while the burned clay is present throughout the archeological deposits (to a depth of $100 \mathrm{~cm}$ bs). The highest densities of burned clay in the controlled excavations are from $10-40 \mathrm{~cm}$ bs, where $65 \%$ of the burned clay was found.

\section{Clay Coil}

A single clay coil in Unit $21(60-70 \mathrm{~cm}$ bs) is direct evidence that ceramics were actually being made at the Polk Estates site. The vessels were apparently made up of thin coils of clay that were stacked one atop another to form the vessel, then scraped and smoothed to create uniformly thick vessel body walls. The one clay coil we found had obviously been exposed to fire before it could be used in vessel manufacture.

\section{Chipped Stone Tools}

The chipped stone tools recovered during our work at the Polk Estates site includes one chipped and polished ferruginous sandstone gouge, nine arrow points, 11 dart points, six flake tools, a perforator, three arrow point preforms, and six bifaces.

The arrow points are concentrated in the upper $40 \mathrm{~cm}$ of the archeological deposits, but were uncovered from as deep as $90 \mathrm{~cm}$ bs in prehistoric Caddo contexts. The dart points, on the other hand, are primarily found from $50-90 \mathrm{~cm}$ bs, below the arrow points, but three of the dart points also came from $30-40 \mathrm{~cm}$ bs in the handexcavated units, and one was found in a shovel test between $0-20 \mathrm{~cm}$ bs.

The arrow points have primarily expanding stems and are corner-notched, with saerrated blades (Figure 13). Two have parallel stems and flat bases (Figure 13c-d), including one made from a gray novaculite. The other arrow points are made from a heattreated quartzite or a brown chert. The arrow point preforms (see Figure 16b) are ovoidshaped, are thicker than the finished arrow points, and were discarded before the stem was finished by notching the preform.

All of the dart points from the Polk Estates site are made on local heat-treated quartzite. They include five contracting stem Gary points (Figure 14a-b) and four Yarbrough points (Figure 14c-f), along with a tip and a dart point mid-section. The Gary points were found from $30-40 \mathrm{~cm}$ to $80-90 \mathrm{~cm}$ bs, while the Yarbrough points came from $30-60 \mathrm{~cm}$ in the hand-excavated units. 


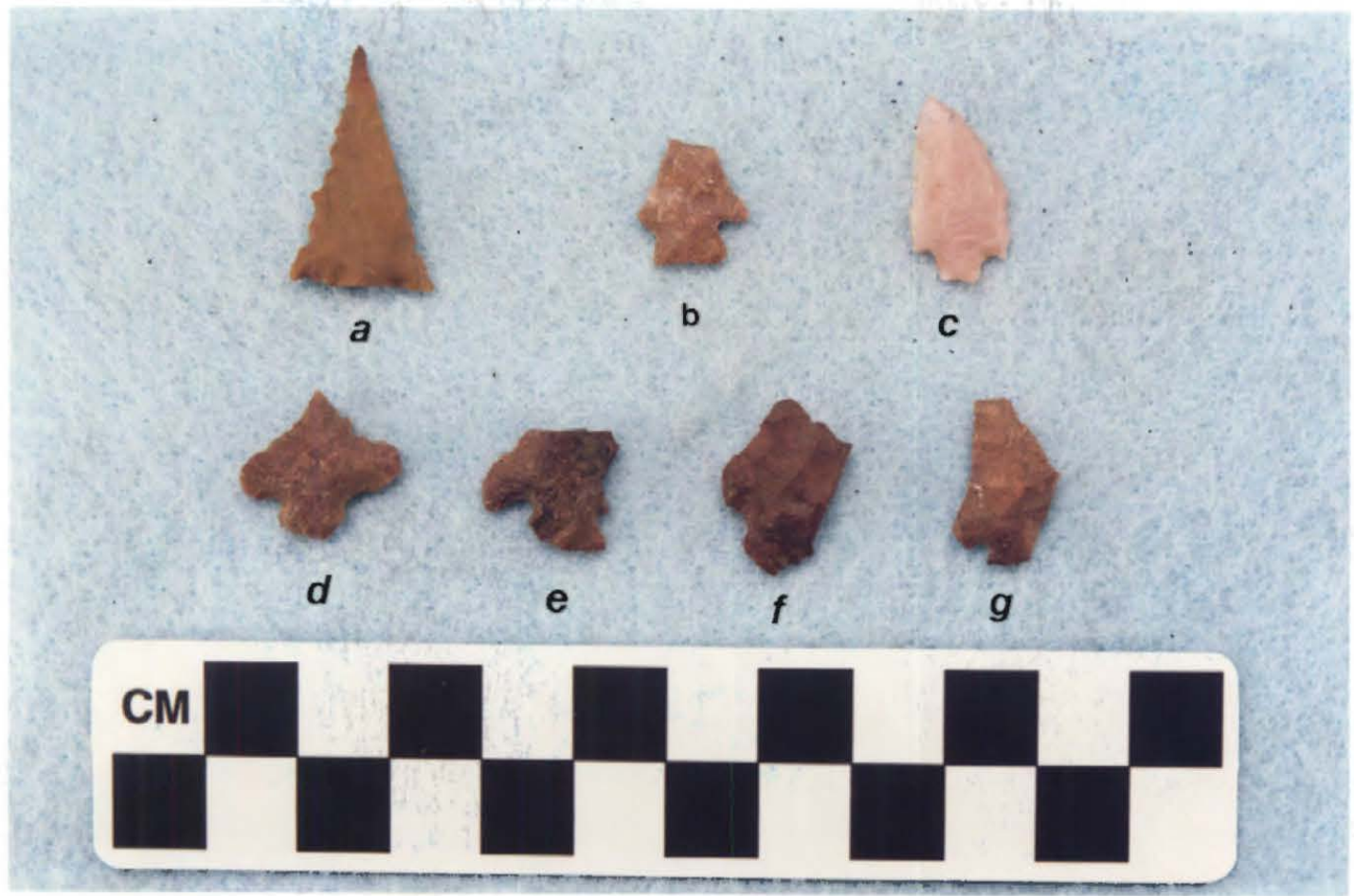

Figure 13. Arrow points from the Polk Estates site. Provenience: a, Unit 21, 70-80 cm; b, Unit 21, 80-90 cm; c, ST 27, 40-50 cm; d, Unit 22, 30-40 cm; e, Unit 1, 20-30 cm; f-g, Unit $21,30-40 \mathrm{~cm}$.

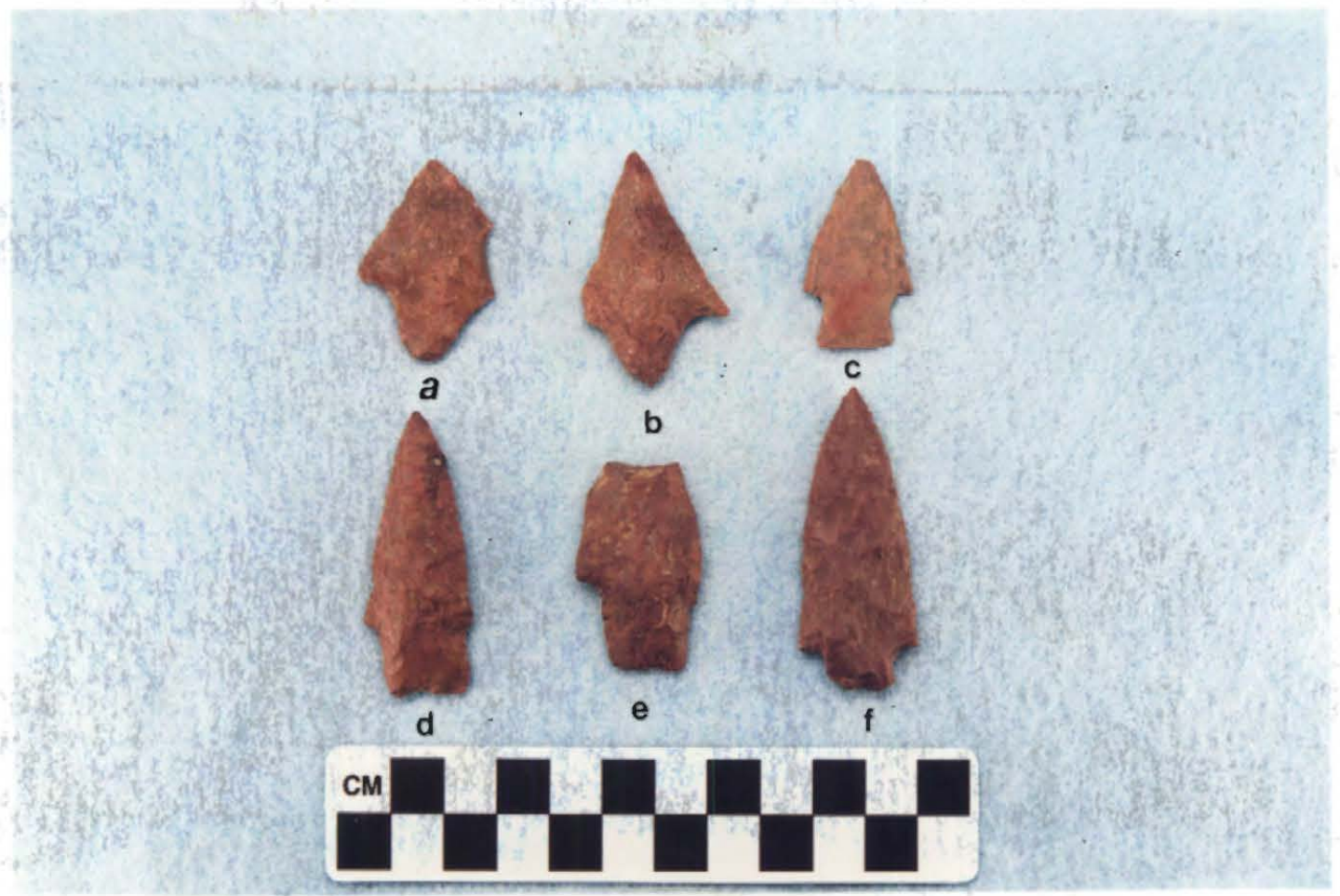

Figure 14. Dart points. Provenience: a, Unit $21,30-40 \mathrm{~cm}$; b, Unit 21, 70-80 cm; c, Unit 22/22A, 50-60 cm; d-e, Spoil Pile; f, Unit 1, disturbance, $31 \mathrm{~cm}$. 
The bifaces, all on quartzite, represent discarded manufacturing attempts to make bifacial tools. They tend to be ovoid-shaped, with thick profiles, with most of the cortex removed (Figure 15a-c). They have been shaped primarily by hard hammer percussion, and were discarded before they were completely thinned or shaped with pressure flaking along the bifacial tool edge. None of the bifaces have any evidence of use. More than $80 \%$ of the bifaces were recovered between $50-100 \mathrm{~cm}$ bs, in the deeper part of the site's archeological deposits, and are probably of Woodland and Late Archaic derivation.

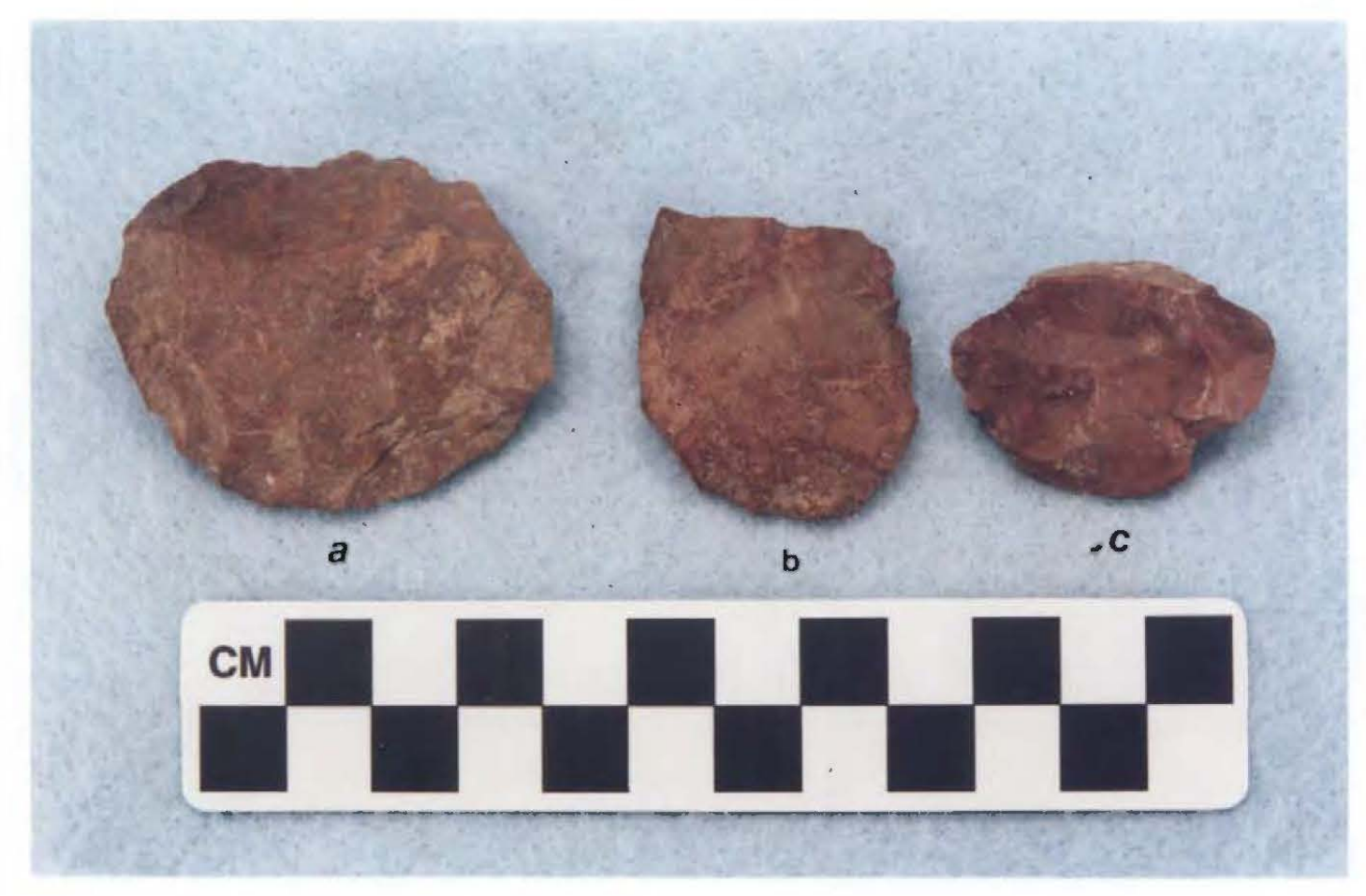

Figure 15. Bifaces. Provenience: a, Unit 21, 60-70 cm; b, Unit 21, 70-80 cm; c, Spoil Pile screening.

Among the flake tools is a single flake perforator from ST 1, 60-80 cm bs. Other flake tools include unilateral and bilateral expedient flake tools (Figure 16a) probably used for the occasional cutting and scraping needs of the site occupants. There are no formal knifes or scrapers in the assemblage. The flake tools were made from quartzite, a dark brown chert, and novaculite raw materials. The flake tools came from $0-20 \mathrm{~cm}(\mathrm{n}=2)$ or from depths greater than $60 \mathrm{~cm}$ bs $(n=3)$, suggesting the use of flake tools during different occupations at the site. 


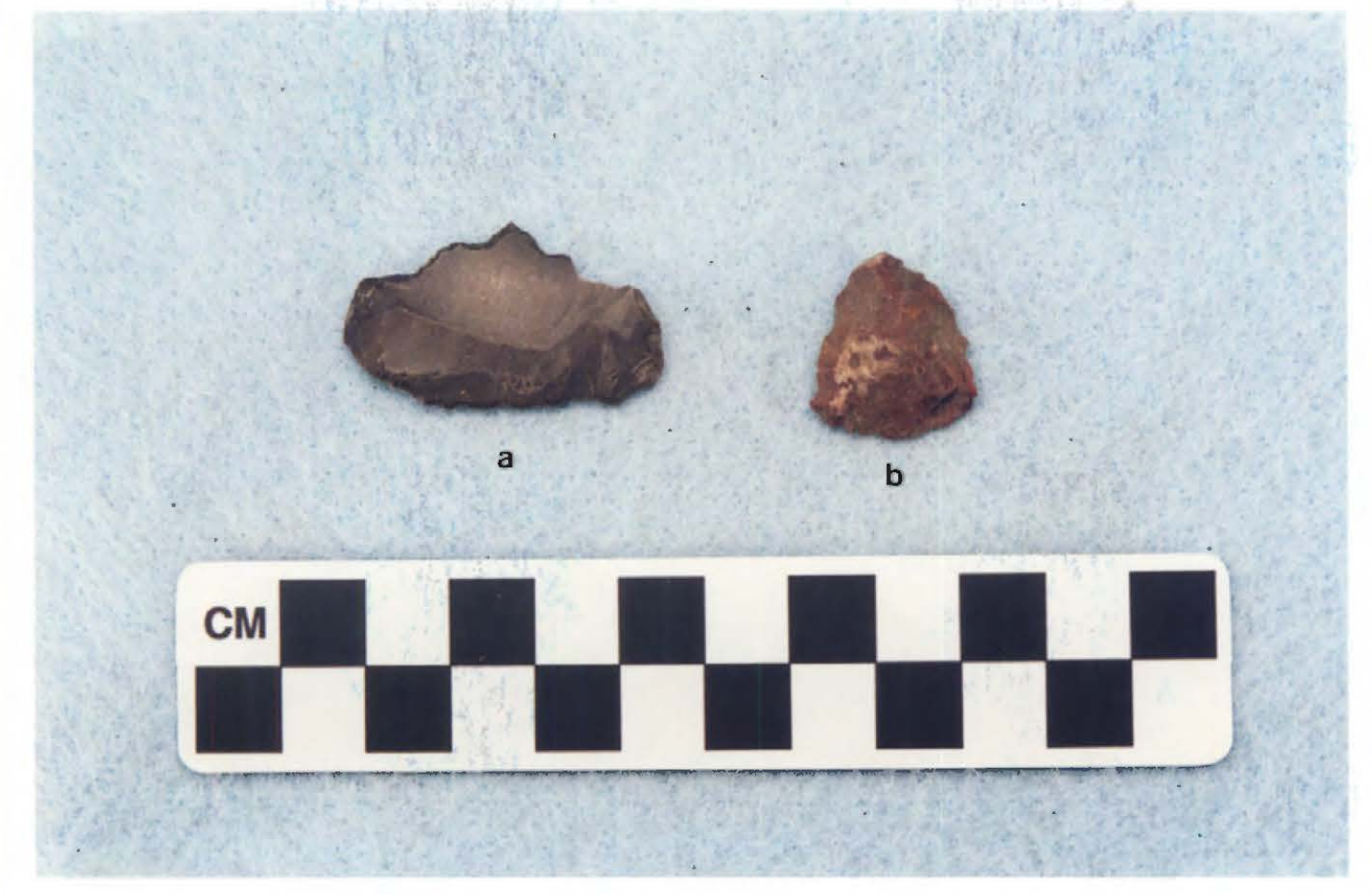

Figure 16. Flake tool and arrow point preform. Provenience: a-b, Unit 21, 60-70 cm.

\section{Ground stone Tools}

There are six ground stone tools in the assemblage. These include manos $(n=2)$ and pitted stones $(n=2)$, as well as multi-functional manos with a central pit or depression on it suggesting some plant food processing using coarse-grained rocks during the prehistoric occupation at the Polk Estates site. The ground stone tools were found on the surface as well as in the excavations, where they were recovered between $20-80 \mathrm{~cm}$ bs. Only $40 \%$ of the ground stone tools found in the excavations come from deeper than 40 $\mathrm{cm}$, suggesting the use of the tools was actually concentrated in the prehistoric Caddo component.

One ferruginous sandstone gouge (Figure 17) was found in ST 15, $90-100 \mathrm{~cm}$ bs in Woodland period contexts. The gouge has a steep unifacial working edge, has been chipped to shape, and the face of the tool opposite the working edge is highly polished from use. 


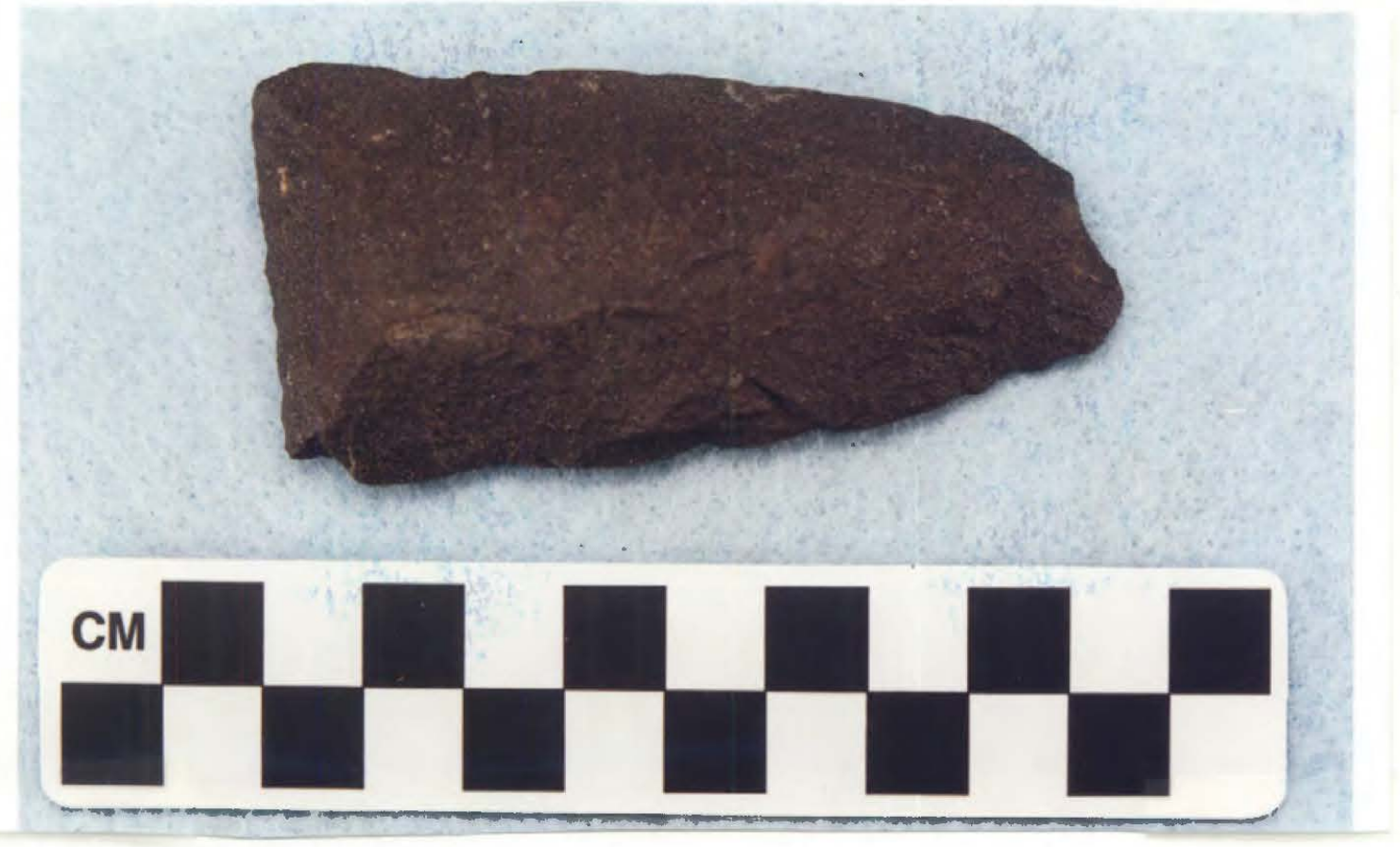

Figure 17. Gouge, ST $15,90-100 \mathrm{~cm}$.

\section{Lithic Debris and Cores}

Among the lithic debris ( $\mathrm{n}=1233$ along with 10 cores), quartzite pieces by far are the predominant raw material that was being kanpped by the Native Americans that lived at the Polk Estates site. By level, quartzite accounts for between $60-100 \%$ of all the lithic debris. In those levels (1v. 1-7, or 0-70 cm bs) that have a total of more than 45 pieces of lithic debris, quartzite comprises 72.1-91.3\% of each level's assemblage. The highest percentage of quartzite lithic debris is level $3(20-30 \mathrm{~cm}$ bs), followed by level $7(88.9 \%)$, bith Caddo contexts. The quartzite, along with the majority of the other raw materials, was likely collected in nearby stream and/or upland gravel sources.

The other lithic raw materials include petrified wood, hematite, various cherts, and novaculite. The cherts include the following colors: gray, dark gray, red, grayishbrown, yellowish-brown, reddish-brown, brown, and dark brown.

The petrified wood, gray chert, and red chert (in that order) are relatively abundant in the Polk Estates lithic debris, but do not account for $17 \%$ of the lithic debris in any one level of the archeological deposits. The gray chert is confined almost exclusively to the upper $50 \mathrm{~cm}$ of the deposits, accounting for $2.9-7.4 \%$ of the lithic debris in those prehistoric Caddo levels. The red chert is found throughout the deposits, and ranges in frequency from $1.7-8.7 \%$ by level (the highest percentage occurs in level 1). Petrified wood lithic debris is only found below $30 \mathrm{~cm}$ in the archeological deposits, with the highest relative frequency between $30-50 \mathrm{~cm}$ bs $(7.4-7.8 \%)$.

In general, while quartzite lithic debris is common throughout the deposits-indicating a continuing preference for the use of this local raw material - cherts of various sorts are predominant only between $0-40 \mathrm{~cm}$ bs, where it 
comprises $13.0-17.3 \%$ of the lithic debris. The frequency of chert use declines below 40 $\mathrm{cm}$ bs and in deposits that date before ca. A.D. 1200.

The one obvious non-local lithic raw material in the lithic debris is novaculite. This material originates in the Ouachita Mountains of southeastern Oklahoma and southwestern Arkansas, but can also be found in Red River and Bowie gravels. These gravels are located well to the north and northeast of the Big Cypress Creek basin. The frequency of novaculite use in the lithic debris ranges from $1.5-10 \%$ by level, although the $10-20 \mathrm{~cm}$ and $50-70 \mathrm{~cm}$ bs levels did not contain novaculite. The highest frequency of use was in the $70-90 \mathrm{~cm}$ bs levels (6.7-10\%), probably in easrly Caddo or Woodland period times.

The 10 cores are either on quartzite $(90 \%)$ or a red chert (10\%). They include tested cobbles as well as single and multiple platform flake cores, suggesting an expeditious use of local raw materials, where materials were reduced to assess their suitability for further kanpping and to thin and shape pebbles and small cobbles for bifacial and unifacial tools. Sixty percent of the cores were recovered below $50 \mathrm{~cm}$ bs, suggesting they are associated with the earlier use of the Polk Estates site, and the predominant focus on core reduction knapping strategies.

\section{Fire-cracked Rock}

The low density (16 pieces) of fire-cracked rock in the artifact assemblage suggests that indirect heating/cooking methods using heated rocks was not much in use during the occupation of the Polk Estates site. Instead the Caddo occupants primarily used direct heating methods by cooking foods in ceramic vessels. Of the fire-cracked rock not found in surface contexts, most of it came from deep in the archeological deposits (i.e., below $60-70 \mathrm{~cm}$ bs), and are probably not associated with the Early and Middle Caddoan period occupatios of the site, but instead with the Woodland period.

\section{Human Remains}

No burials were encountered during our limited investigations, but small pieces of human remains were recovered from ST $2(0-20 \mathrm{~cm})$, ST $19(70-80 \mathrm{~cm}$ bs), and ST 20 $(40-50 \mathrm{~cm})$ (Diane Wilson, 2000 personal communication). These remains probably originated from the looter backdirt or other pit excavations in the Polk Estates archeological deposits. None of these human remains have been further studied at this time.

\section{Faunal Remains}

More than 390 animal bones were recovered in the archeological deposits at the Polk Estates site (see Appendix 2, this volume). Among the animal species identified in the small sample of remains are turtle and deer. The majority of the animal remains (although unidentifiable) are from large mammals or deer-sized artiodactyls, but one long 
bone is from a bison-sized artiodactyl. This bone was recovered in the Middle Caddoan period archeological deposits, suggesting some use of this prairie animal.

\section{Summary}

The Polk Estates site (41CP245) is an intensively occupied prehistoric Late Archaic, Woodland, Early Caddo and Middle Caddo period site on a large natural rise in the Big Cypress Creek basin. It also had a Late Caddo Titus phase cemetery on the site, but it unfortunately had been damaged by collectors and others over the years.

Our work began with documenting the extent of the previous work at the site, and during our reconnaissance and mapping, we identified approximately 21 burial-sized holes on the rise that were apparently part of the Titus phase cemetery. During our work at the Polk Estates site-which consisted of shovel testing and a few hand-excavated units-we also documented that there are extensive and thick $(\mathrm{ca} .160 \mathrm{~cm}$ ) archaeological deposits at the site, including a midden, from use of the landform prior to its use as a prehistoric Caddo cemetery.

In our experience, it is unusual to fine a Titus phase cemetery on the same landform that has significant archaeological habitation deposits. Usually, there is little to no (i.e., an occasional Archaic projectile point) habitation debris from earlier use of the same area as cemeteries. This suggests an overall deliberate placement of cemeteries on the cultural landscape (i.e., separate from habitation areas or areas associated with the living), as well as a sanctity to the choice of where to establish cemeteries during the Titus phase. Why these practices were not followed during the Titus phase use of the Polk Estates site as a cemetery is not known.

$\mathrm{OCR}$ and radiocarbon dates, as well as the recovered artifacts, suggest that the Polk Estates site has stratified archaeological deposits that extend back to the Late Archaic (ca. 3500-5200 years ago). There appear to also be Woodland, Early Caddo, and Middle Caddo occupational deposits, and the latter are marked by a discrete midden deposit on the center of the natural rise. Since the elevation of the rise is well above levels that could be reached by flooding of Big Cypress Creek, aggradation of the sandy deposits on the rise was generally rather slow (with the exception of the rapid accumulation of the midden deposits), probably as a result of aeolian deposition. The rate of aggradation can be approximated at $0.068 \mathrm{~cm}$ per year or approximately $6.8 \mathrm{~cm}$ over an 100 year span of time.

The site was clearly used as a domestic habitation area by the Caddo Indians, who appear to have occupied the site on several occasions. During that occupation, there probably was at least one thatch-covered structure on the site, and the inhabitants likely cultivated the nearby Big Cypress Creek floodplain to grow corn, beans, and squash. They made their own ceramic vessels for cooking and serving, and manufactured arrow points and flake tooks for expedient uses around the homestead. They were successful hunters as well, gathering deer and turtle, and the recovery of one bison-sized long bone in the Middle Caddo archaeological 
deposits suggests some use of this prairie animal, a considerable source of meat that may have been mainly dried and jerked at the kill site.

The last use of the site took place sometime between ca. A.D. 1430-1680, during the Titus phase. The use of the site was not domestic, but as a cemetery of 20-30 individuals. This is about the average size of a Titus phase cemetery (Perttula 2005, ed.: 377). It was probably used by a series of extended family members over a considerable period of time. The Titus phase community that used the Polk Estates site as a cemetery were probably part of the political community centered at the nearby Pilgrim's Pride site (41CP304). This community is represented by clusters of interrelated settlements and associated cemeteries that are centered on a key site or group of sites distinguished by public architecture (i.e., earthen mounds) and large domestic village areas.

We hope to be able to return in the future to the Polk Estates site to carry out additional archaeological investigations. It is important in future work to be able to establish the domestic character of the Early and Middle Caddo occupations by identifying features and structure locations across the natural rise. Also key is to better define the stratigraphic character of the archaeological deposits at the site, particularly the more deeply buried Woodland and Late Archaic occupations, and obtain more radiocarbon dates on these early occupations.

\section{Acknowledgments}

We thank the past and present landowners for permission to work at the site on their land, and also for the opportunity to study the recovered artifacts. We than the John Polk family, especially Scott Polk, who got things going, and allowed us to conduct the work. Mr. George H. Jones and Maurine Jones, current landowners, also allowed us to work on the property after ownership of the land was transferred. They also have been very interested and supportive of our work. WE also thank Mr. Donald Doddy, rancher foreman for the Rafter M Ranch, for his interest and assistance after the land transfer.

We also appreciate the help in the field provided by Mark Walters and Mike Turner. Bobby Gonzalez also assisted in some of the work at the site during Nelson's site visits, including the excavation of shovel tests. Sandy Hannum and Nancy Reese prepared maps and figures used in this report. Bo Nelson took the artifact photos.

\section{References Cited}

Nelson, B. and T. K. Perttula

1997 Documenting Looted Early, Middle, and Late Caddoan Cemetery Sites in Northeast Texas. The Steward 4:3-14. Collected Papers on Texas Archeology, Office of the State Archeologist, Texas Historical Commission, Austin 
Perttula, T. K.

2005 Caddo Agriculture on the Westem Frontier of the Eastem Woodlands. MS on file with the author, Austin, Texas.

Perttula, T. K. (editor)

2005 Archeological Investigations at the Pilgrim's Pride Site (41CP304), a Titus Phase Community in the Big Cypress Creek Basin, Camp County, Texas. 2 Vols. Report of Investigations No. 30. Archeological \& Environmental Consultants, LLC, Austin.

Perttula, T. K. and B. Nelson

1999 The Looting of Prehistoric Caddo Indian Cemeteries in Northeast Texas. Texas Forum on Civil Liberties \& Civil Rights 4(1):77-86.

Roberts, K.

1990 Soil Survey of Camp, Farnklin, Morris, and Titus Counties, Texas. United States Department of Agriculture, Soil Conservation Service, in cooperation with Texas Agricultural Experiment Station and Texas State Soil and Water Conservation Board.

Suhm, D. A. and E. B. Jelks (editors)

1962 Handbook of Texas Archeology: Type Descriptions. Special Publication No. 1, Texas Archeological Society and Bulletin No. 4, Texas Memorial Museum, Austin. 
Appendix 1,

Shovel Test Descriptions 
ST $1 \quad 0-100 \mathrm{~cm}+$, grayish-brown sandy loam

ST $2 \quad$ 0-43 cm, dark brown sandy loam (midden); 43-100 cm+, grayish-brown sandy loam

ST $3 \quad$ 0-42 cm, dark brown sandy loam (midden); $42-91 \mathrm{~cm}$, grayish-brown sandy loam; 91-100 cm+, light grayish-brown sandy loam

ST $4 \quad 0-100 \mathrm{~cm}+$, grayish-brown sandy loam

ST $5 \quad$ 0-43 cm, dark brown sandy loam (midden); 43-100 cm+, grayish-brown sandy loam

ST 6 0-131 cm+, grayish-brown sandy loam

ST 7 0-100 cm+, grayish-brown sandy loam

ST 8 - $100 \mathrm{~cm}+$, grayish-brown sandy loam

ST $9 \quad 0-72 \mathrm{~cm}$, grayish-brown sandy loam; $72-75 \mathrm{~cm}+$, orange clay

ST $10 \quad 0-16 \mathrm{~cm}$, dark brown sandy loam; 16-100 cm+, brown sandy loam

ST $11 \quad$ 0-31 cm, dark brown sandy loam (midden); 31-89 cm, brown sandy loam; $89-100 \mathrm{~cm}+$, light brown sandy loam

ST $12 \quad$ 0-11 cm, dark brown sandy loam; $11-86 \mathrm{~cm}$, brown sandy loam; 86-88 $\mathrm{cm}+$, orange clay

ST $13 \quad 0-104 \mathrm{~cm}+$, brown sandy loam

ST $23 \quad 0-15 \mathrm{~cm}$, light brown sandy loam; 15-70 $\mathrm{cm}+$, dark brown sandy loam

ST $24 \quad 0-35 \mathrm{~cm}$, brown sandy loam; $35-60 \mathrm{~cm}$, light brown sand; $60 \mathrm{~cm}+$, orange clay

ST $25 \quad 0-40 \mathrm{~cm}$, brown sandy loam; 40-68 cm, light brown sandy loam; 68-70 $\mathrm{cm}+$, orange clay

ST $26-68 \mathrm{~cm}+$, brown sandy loam

ST $27 \quad 0-46 \mathrm{~cm}$, dark brown sandy loam (midden); $45-82 \mathrm{~cm}+$, light brown to grayish-brown sandy loam 
ST $28 \quad 0-81 \mathrm{~cm}$, dark brown sandy loam; $81-86 \mathrm{~cm}+$, orange clay

ST $29 \quad$ 0-79 $\mathrm{cm}$, dark brown sandy loam (midden?); $79-82 \mathrm{~cm}+$, orange clay 
Appendix 2,

Faunal Analysis, by LeeAnna Schniebs 
FAUNAL ANALYSIS: $41 \mathrm{CP} 245$

\section{INTRODUCTION}

The excavation of 41CP245, an Early and Middle Caddoan settlement on Big Cypress Creek in Camp County, Texas, yielded 391 faunal specimens. Total weight of the assemblage is 259.6 grams, just over nine ounces. This sum includes all bone, antler, and turtle shell fragments. Faunal material was recovered from a total of ten 10 shovel tests, five excavation units, and one feature. The following sections discuss the methods employed in the faunal analysis, results of taxonomic identification and quantification, and distribution of these remains.

\section{METHODOLOGY}

All prehistoric vertebrate remains were inventoried and weighed. Excel 5.0 for Windows was used to manipulate the generated data. An Ohaus digital scale, Model CT600-S, was used to record bone weight. All fragments recovered were analyzed by the author, using comparative collections on loan from or housed at the Institute of Applied Sciences, Zooarchaeology Lab, University of North Texas, Denton, Texas. Occasional supplements were required, using conventional osteological keys such as Olsen (1964), Gilbert (1980), and Schmid (1972). Identifications were made to the most specific category possible depending on condition of the bone and available comparative material. Only positive identifications resulted in the assignment of elements to genus or species.

Standard zooarchaeological methods have been used. The animal bones were inventoried and bagged by Archeological and Environmental Consultants, then submitted for identification and quantification. Both unidentifiable and identifiable pieces were analyzed in similar fashion. That is, the same attributes were recorded: taxon, element and portion of that element, anatomical location of the element, condition of the bone and any notes on age, taphonomy, burning or breakage patterns, and presence of modification if applicable. Provenience information was also recorded.

Quantification of the assemblage is summarized as minimum number of identified specimens per taxon (NISP) and as minimum number of individuals (MNI) for identified elements. MNI estimates were calculated according to the most frequently occurring element, based on symmetry and element portion (Munzel 1986). In some cases, complete long bones and proximal or distal ends were considered. In other cases, the presence of a single element constituted an MNI of one.

The faunal data tables in this report are standard species lists with the number of occurrences for each animal. Those specimens regarded as unidentifiable (those coded to only class or order) have been consolidated into a few general categories. Elements of nondiagnostic skeletal value (ribs, vertebrae and long bone shafts; Olsen 1964), are coded in an indeterminate category by class and/or size range. For example, specimens counted as "small mammal" are from gopher or rabbit-size mammals, and "large mammal" refers to a deer-size mammal. Bones recorded as "mammal" are size unknown, and "indeterminate vertebrate" includes the bones uncertain of class. Recording these specimens in a size category enables the most precise level of observation as the specimen allows. 
In small samples, taking note of weight and the size categories of nondiagnostic elements broadens the function of the bone assemblage. However, percentages referred to in this report are calculated by number of bones (NISP) rather than weight. Weights of specimens can be found in the faunal data sheets.

\section{RESULTS}

The following section describes the vertebrate taxa recovered from 41CP245. Taxonomic classes identified include reptile and mammal (xenarthra and artiodactyla). The faunal assemblage from $41 \mathrm{CP} 245$ is dominated by unidentifiable large mammal remains. Number of identified specimens (NISP) and minimum number of individuals (MNI) for each taxon are summarized in Table 1, as are weights for each taxon and percentages of site assemblage. Composition of anatomical elements can be found in Table 2 .

Assemblage Composition

Class Reptilia

Order Testudinata (family indeterminate): Five small shell fragments from unidentifiable turtle were recovered from two shovel tests and two excavation units. Depths range from 0 to 100 centimeters below surface (cmbs). Two fragments were found in the Early Caddoan Deposits (80 to $100 \mathrm{cmbs}$ ), and three pieces came from Middle Caddoan Deposits ( 0 to $60 \mathrm{cmbs}$ ). This includes one specimen from a fine screen sample taken in Unit 21 (40 cmbs). Four fragments are burned.

\section{Class Mammalia}

Order Xenarthra, Family Dasypodidae: Nine-banded armadillo (Dasypus novemcinctus) is represented by one element. It was recovered from Shovel Test 2 ( 0 to $20 \mathrm{cmbs}$ ). This stained specimen is from an immature individual. The armadillo prefers woodlands, brushy areas, rock outcrops, and cliffs. Presently, it's range includes much of Texas, Oklahoma, southeastern Kansas, southwestern Missouri, most of Arkansas and Mississippi, Louisiana, Florida, and parts of Georgia and Alabama. Their body is covered with a protective shell made of scutes, and is capable of rolling into a ball for protection. They are beneficial as insect eaters, and their meat is edible (Burt 1980). This specimen is probably intrusive and does not reflect prehistoric debris.

Order Artiodactyla, Family Cervidae: Deer (Odocoileus sp.) is represented by 19 specimens, comprised of two complete teeth and 17 tooth fragments. They were recovered from two shovel tests and two excavation units, with depths ranging from 30 to $100 \mathrm{cmbs}$. Based on tooth wear patterns on the complete teeth, it was determined that the individual was about four years of age at the time of death. These are most likely the rcmains of white-tailed deer (Odocoileus virginianus). This is the only species that currently occupies the project area, found in forests, swamps, and open brushy areas nearby (Burt 1980). Prehistorically, other species may have been present, but the elements found in this site assemblage are from smaller individuals. Whitetail deer are known for their small 
size, as compared to the larger mule deer of the western United States. At least one individual was present at the site. Additionally, 46 medium artiodactyl bone fragments were recovered from several excavation units, two shovel tests, and Feature 1. Contexts include the Early as well as Middle Caddoan deposits. Sixteen medium artiodactyl bones are burned. Medium artiodactyl (deer) is probably also represented in the unidentifiable large mammal category $(\mathrm{N}=245)$. Eighty six large mammal bone fragments are burned.

Family Cervidae is also represented by one antler fragment. This burned specimen was recovered from Unit 21, at 90 to $100 \mathrm{cmbs}$. This is probably the remains of deer rather than elk, as elk does not occur in the project area.

Order Artiodactyl (family indeterminate): Large artiodactyl is represented by one metapodial fragment. It was recovered from Feature 1 (Burial Pit 1) at 0 to $40 \mathrm{cmbs}$. The specimen is not burned, but is abraded and exfoliated. This is most likely the remains of bison (Bison sp.) rather than domestic cow based on the context of the specimen. Preferring open plains and grasslands (Burt 1980), bison and deer were main subsistence animals of the Caddo. At least some of the large mammal bones may also represent large artiodactyl.

Only two small mammal bones are included in the $41 \mathrm{CP} 245$ faunal collection. They compare favorably to cotton rat, but because of fragmentation a specific identification was not recorded. Hispid cotton rat (Sigmodon hispidus) is the only cotton rat that occurs in the project area, preferring tall grass, sedges, weeds, and moist areas (Burt 1980). One specimen was recovered from Unit 1 (0 to $10 \mathrm{cmbs})$, and the second piece came fromUnit $21(40 \mathrm{cmbs})$. The second fragment is burned and was retrievcd from a fine screen sample.

\section{Assemblage Condition}

In general, the $41 \mathrm{CP} 245$ faunal sample is poorly preserved and highly fragmented. This may be evidence of boiling for bone grease. Abrasion and exfoliation are the most common surface observations (Table 3). Light root etching is visible on 13 specimens, and the armadillo bone is the only element that is humic stained. The remaining 156 fragments are devoid of any taphonomic patterns. One hundred forty seven specimens are burned $(38 \%)$, most likely the result of trash disposal. The Middle Caddoan deposits in Unit $21(0$ to $70 \mathrm{cmbs})$ yielded the majority of burned bones $(\mathrm{N}=67)$. Totals from other shovel test pits and excavation units range from one to 18 . Only one burned fragment was recovered from Feature 1 (Burial Pit 1). Summary of burned specimens can be found in Table 4, and the distribution of these burned remains can be found in Table 5 .

Scavenging activities at the site were minimal. Rodent gnawing was observed on 14 large mammal bone fragments and seven medium artiodactyl bone fragments. These specimens were recovered from several different areas (Table 6). 
Distribution

The following section organizes the $41 \mathrm{CP} 245$ faunal collection according to recovery by temporal deposits. The distribution of faunal remains is summarized in Tables 7 through 9.

Early Caddoan Deposits (N=95)

Estimated date of these deposits is $\mathrm{AD} 790$ to 850 . A total of 95 faunal specimens were recovered from six shovel test pits and two excavation units at depths ranging from 70 to $100 \mathrm{cmbs}$. Taxonomic recovery is comprised of indeterminate vertebrate, turtle, indeterminate mammal, large mammal, medium artiodactyl, cervid (antler), and deer. Recovery from each unit was relatively minimal, with totals ranging from one to eight specimens. The exception is Unit $21(\mathrm{~N}=76)$, dominated by large mammal remains. A total of 15 fragments are burned, including nine secimens from Unit 21.

Early/Middle Caddoan Deposits (N=3)

Two shovel test pits include the transition between the Early and Middle Caddoan deposits. Shovel Test 2 yielded two large mammal bones, and one large mammal bone was recovered from Shovel Test 3. These specimens were recovered from 60 to $80 \mathrm{cmbs}$. Two fragments are burned.

Middle Caddoan Deposits (N=293)

Estimated date of these deposits is AD 1180 to 1370 . A total of 293 faunal specimens were recovered from nine shovel test pits, five excavation units, and one feature. Depths range from 0 to 70 centimeters below surface. One hundred forty one fragments are burned, $48 \%$ of the Middle Caddoan deposits. Taxonomic recovery is similar to that of the Early deposits, but also includes small mammal, armadillo, and large artiodactyl remains. Shovel tests yielded minimal quantities, with totals ranging between one and 15 specimens. Unit $21(0$ to $70 \mathrm{cmbs})$ yielded the majority of faunal material ( $\mathrm{N}=127)$, including 61 large mammal bones, 25 medium artiodactyl bones, and eight deer tooth fragments. The remaining excavation units yielded less than 40 specimens each, and most of the recovery is dominated by large mammal remains. Unit $22 / 22 \mathrm{a}$ (50 to $60 \mathrm{cmbs}$ ) is the only unit devoid of large mammal bones.

Feature 1 (Burial Pit 1) yielded 19 large mammal bones, two medium artiodactyl bones, and the only large artiodactyl element in the entire site sample. These remains were recovered from 0 to $40 \mathrm{cmbs}$, and only one large mammal bone fragment is burned.

\section{SUMMARY}

Faunal material found in the Early Caddoan deposits at $41 \mathrm{CP} 245$ suggests a dietary reliance on large game animals, occasionally supplemented by turtles. The Middle Caddoan deposits are taxonomically similar, although quantites are higher. The $41 \mathrm{CP} 245$ faunal sample is evidence of 
subsistence refuse deposited over time.

41CP245 is located one mile southeast of Pilgrim's Pride Site (41CP304), a Late Caddoan Titus Phase residential area. A total of 239 bones were recovered.Taxonomic classes identified include fish, reptile, and mammal (lagomorpha and artiodactyla). The faunal assemblage is dominated by unidentifiable mammal and large mammal remains. The sample is evidence of dietary refuse, reflecting the utilization of available resources including large game animals, supplemented by fish, turtle, and rabbit. Taxonomic composition is typical of Caddoan faunal assemblages.

41CP245 is located ten miles southeast of the Shelby Mound Site (41CP71), a Titus Phase mound deposit on Greasy Creek, also in Camp County, Texas. The faunal assemblage is considerably larger (over 3000 funal specimens). Taxonomic classes identified include fish, amphibian, reptile, ave, and mammal (lagomorpha, rodentia, carnivora, and artiodactyla). Seven faunal specimens are modified. The faunal collection from 41CP71 indicates that the Caddo diet consisted of large and small game, including deer, squirrels, and rabbits, supplemented with fish, turtles, and birds. A shift in subsistence strategies is suggested by the increase in faunal recovery as the levels deepen at this site.

When compared to the two nearby sites, the faunal assemblage from $41 \mathrm{CP} 245$ completes a small overview of Caddoan subsistence practices over time. The earlier periods suggest the utilization of larger game animals, with occasional supplements of smaller animals such as turtle. The more recent samples suggest broader choices, including more aquatic animals and more rabbits (probably a benefit from garden hunting strategies). This indicates a more stable and increased population of a farming community in the later occupations. 


\begin{tabular}{|c|c|c|c|c|c|c|c|c|c|c|c|c|c|}
\hline UnitST & cmbs & Context & Qty & Taxon & Elem/Por & Side & Age & Taph & Burn & Gnaw & Mod & Wtg & Comments \\
\hline ST 15 & 70 to 80 & early & 1 & lg mam & unid & & & abrade,exf & inot & & & 0.1 & \\
\hline ST 15 & 70 to 80 & early & 1 & lg mam & I.b.frag & & & absent & wh & & & 0.4 & \\
\hline ST 15 & 80 to 90 & early & 5 & deer & tooth frg & & & absent & not & & & 0.5 & \\
\hline ST 15 & 80 to 90 & early & 1 & unid & unid & & & absent & wh & & & 0.1 & \\
\hline ST 17 & 70to 80 & early & 1 & Ig mam & I.b.frag & & & absent & wh & & & 0.3 & \\
\hline ST 19 & 80 to 90 & early & 1 & Ig mam & unid & & & abrade & not & & & 0.1 & \\
\hline ST 20 & 70 to 80 & early & 1 & mammal & unid & & & absent & char & & & 0.1 & \\
\hline ST 3 & 80 to 100 & early & 3 & mammal & unid & & & abrade & not & & & 0.1 & \\
\hline ST 3 & 80 to 100 & early & 1 & turtle & shell frg & & & absent & wh & & & 0.2 & \\
\hline ST 8 & 80 to 100 & early & 1 & Ig mam & unid & & & absent & wh & & & 0.2 & \\
\hline U1 & 85 & early & 2 & lg mam & unid & & & abrade,exf & not & & & 0.8 & \\
\hline U1 & 85 & early & 1 & Ig mam & I.b.frag & & & etch light & not & & & 0.5 & \\
\hline U 21 & 90 & early & 17 & mammal & unid & & & abrade,exfi & not & & & 1 & fine screen \\
\hline U 21 & 70 to 80 & early & 1 & Ig mam & I.b.frag & & & absent & not & rodent & & 0.2 & \\
\hline U 21 & 70 to 80 & early & 4 & Ig mam & l.b.frag & & & abrade & not & & & 1.3 & \\
\hline U 21 & 70 to 80 & early & 1 & Ig mam & unid & & & abrade,exf & not & & & 0.4 & \\
\hline U 21 & 70 to 80 & early & 1 & lg mam & unid & & & abrade & wh & & & 0.2 & \\
\hline U 21 & 70 to 80 & early & 1 & med art & calc dist & L & & abrade,exf & inot & & & 1.1 & \\
\hline U 21 & 70 to 80 & early & 1 & med art & mtpod cond & dyle & & abrade,exfi & inot & & & 1.8 & \\
\hline U 21 & 70 to 80 & early & 1 & med art & mtpod shft f & & & abrade,exf & inot & & & 0.4 & \\
\hline U 21 & 70 to 80 & early & 1 & med art & phx dist frg & & & abrade, exf & not & & & 0.4 & \\
\hline U 21 & 80 to 90 & early & 1 & Ig mam & I.b.frag & & & etch light & not & rodent & & 3.2 & \\
\hline U 21 & 80 to 90 & early & 16 & Ig mam & unid & & & abrade,exf & not & & & 6.3 & \\
\hline U 21 & 80 to 90 & early & 2 & Ig mam & I.b.frag & & & exfol & not & & & 3.6 & \\
\hline U 21 & 80 to 90 & early & 2 & Ig mam & I.b.frag & & & absent & wh & & & 1.1 & \\
\hline U 21 & 80 to 90 & early & 1 & med art & rad dist frg & $\mathbf{R}$ & & abrade,exf & not & rodent & & 1.8 & \\
\hline U 21 & 80to90 & early & 1 & med art & astrag frg & & & abrade,exf & not & & & 2.1 & \\
\hline U 21 & 90 to 100 & early & 1 & cervid & antler frg & & & absent & wh & & & 0.3 & \\
\hline U 21 & 90 to 100 & early & 1 & deer & tooth frg & & & absent & not & & & 0.2 & \\
\hline U 21 & 90 to 100 & early & 1 & Ig mam & unid & & & exfol & not & rodent & & 0.5 & \\
\hline U 21 & 90 to 100 & early & 16 & Ig mam & unid & & & abrade,exf & inot & & & 1.8 & \\
\hline U 21 & 90 to 100 & early & 4 & lg mam & I.b.frag & & & absent & wh & & & 1.3 & \\
\hline U 21 & 90to100 & early & 1 & med art & mtpod shft f & frg & & abrade,exfi & inot & & & 1. & \\
\hline U 21 & 90 to 100 & early & 1 & turtle & shell frg & & & absent & wh & & & 0.1 & \\
\hline ST 2 & 60 to 80 & early/mid & 1 & lg mam & unid & & & abrade,exf & not & rodent & & 0.8 & \\
\hline ST 2 & 60 to 80 & early/mid & 1 & lg mam & unid & & & abrade,exf & char & & & 0.2 & \\
\hline
\end{tabular}




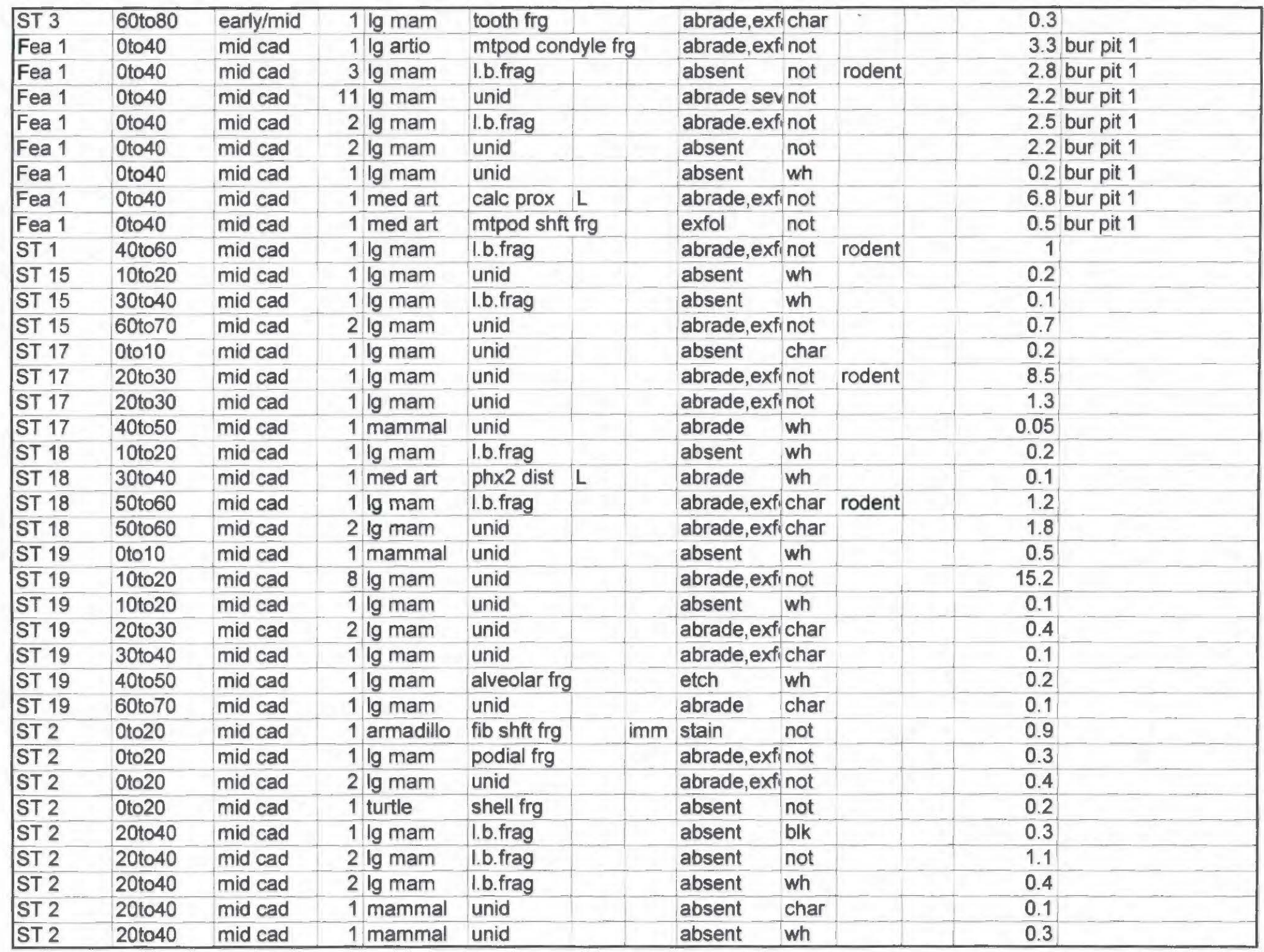




\begin{tabular}{|c|c|c|c|c|c|c|c|c|c|c|c|c|}
\hline ST 2 & 40 to 60 & mid cad & 2 & Ig mam & unid & & & abrade,exfi & inot & & 0.4 & \\
\hline ST 20 & 20 to 30 & mid cad & 1 & Ig mam & I.b.frag & & & absent & wh & & 0.5 & \\
\hline ST 20 & 30 to 40 & mid cad & 1 & deer & tooth frg & & & absent & not & & 0.1 & \\
\hline ST 3 & 20 to 40 & mid cad & 1 & Ig mam & I.b.frag & & & abrade,exfi & not & & 0.2 & \\
\hline ST 3 & 20 to 40 & mid cad & 2 & med art & \multicolumn{2}{|c|}{ mtpod condyle } & & abrade sev & not & & 3.9 & \\
\hline ST 6 & 40 to 60 & mid cad & 1 & Ig mam & unid & & & absent & char & & 1 & \\
\hline U 1 & Oto10 & mid cad & 1 & Ig mam & I.b.frag & & & abrade,exf & not & & 1.1 & \\
\hline U1 & Oto10 & mid cad & 1 & Ig mam & unid & & & abrade,exf & not & & 0.8 & \\
\hline U 1 & Oto10 & mid cad & 3 & Ig mam & unid & & & absent & wh & & 0.6 & \\
\hline U 1 & Oto10 & mid cad & 1 & med art & astragalus & $\mathrm{R}$ & & abrade,exfi & not & & 4.6 & \\
\hline U 1 & Oto10 & mid cad & 1 & sm mam & fem shft frs & $\mathbf{R}$ & & etch & not & & 1 & cf cot'rat \\
\hline U 1 & 10 to 20 & mid cad & 1 & Ig mam & unid & & & abrade,exf & not & & 0.2 & \\
\hline U 1 & 20 to 30 & mid cad & 1 & Ig mam & I.b.frag & & & absent & blk & & 0.2 & \\
\hline U 1 & 20 to 30 & mid cad & 2 & Ig mam & unid & & & abrade,exfi & not & & 0.3 & \\
\hline U 1 & 30 to 40 & mid cad & 2 & Ig mam & unid & & & abrade,exf & not & & 0.9 & \\
\hline U 1 & 30 to 40 & mid cad & 4 & mammal & unid & & & absent & wh & & 0.2 & \\
\hline U1 & 30 to 40 & mid cad & 1 & med art & \multicolumn{2}{|c|}{ mtpod shft frg } & & etch light & not & & 4 & \\
\hline U 1 & 40 to 50 & mid cad & 5 & Ig mam & unid & & & abrade,exfi & not & & 0.8 & \\
\hline U 1 & 40 to 50 & mid cad & 1 & lg mam & unid & & & abrade,exfi & wh & & 0.2 & \\
\hline U 1 & 40 to 50 & mid cad & 1 & mammal & unid & & & absent & char & & 0.1 & \\
\hline U 1 & 50 to 60 & mid cad & 7 & Ig mam & unid & & & abrade,exf & not & & 1.1 & \\
\hline U 1 & 50 to 60 & mid cad & 3 & Ig mam & unid & & & abrade,exf & wh & & 0.6 & \\
\hline U1 & 50 to 60 & mid cad & 1 & med art & \multicolumn{2}{|c|}{ mtpod shft frg } & & abrade,exfi & not & rodent & 1.8 & \\
\hline U 1 & 60 to 70 & mid cad & 1 & Ig mam & unid & & & absent & wh & & 0.2 & \\
\hline U 21 & 10 & mid cad & 2 & mammal & unid & & & absent & wh & & 0.1 & fine screen \\
\hline U 21 & 10 & mid cad & 2 & unid & unid & & & absent & wh & & 0.1 & fine screen \\
\hline U 21 & 20 & mid cad & 1 & mammal & unid & & & abrade & not & & 0.05 & fine screen \\
\hline U 21 & 20 & mid cad & 1 & mammal & unid & & & absent & wh & & 0.05 & fine screen \\
\hline U 21 & 20 & mid cad & 1 & med art & \multicolumn{2}{|c|}{ mtpod shft frg } & & absent & wh & & 0.4 & fine screen \\
\hline U 21 & 40 & mid cad & 1 & sm mam & fem head & $R$ & & absent & wh & & 0.05 & fine screen;cf cot'rat \\
\hline U 21 & 40 & mid cad & 1 & turtle & shell frg & & & absent & char & & 0.1 & fine screen \\
\hline U 21 & 40 & mid cad & 4 & unid & unid & & & absent & wh & & 0.1 & fine screen \\
\hline U 21 & 41 & mid cad & 1 & deer & M2 lo & $L$ & app4 & absent & not & & 3 & \\
\hline U 21 & 41 & mid cad & 1 & deer & M3 lo & $L$ & app4 & absent & not & & 3.5 & \\
\hline U 21 & 41 & mid cad & 6 & deer & tooth frg & & & absent & not & & 0.5 & \\
\hline U 21 & 41 & mid cad & 2 & lg mam & t'root & & & absent & not & & 0.6 & prob deer \\
\hline U 21 & 41 & mid cad & 1 & Ig mam & I.b.frag & & & etch light & blk & & 0.5 & \\
\hline
\end{tabular}




\begin{tabular}{|c|c|c|c|c|c|c|c|c|c|c|c|c|}
\hline U 21 & 41 & mid cad & & lg mam & unid & & & exfol & not & & 0.6 & \\
\hline U 21 & 41 & mid cad & 1 & med art & \multicolumn{2}{|l|}{ b'ramus frg } & & absent & not & rodent & 1.9 & \\
\hline U 21 & 41 & mid cad & 6 & med art & \multicolumn{2}{|l|}{ alveolar frg } & & etch light & not & & 4.4 & prob deer \\
\hline U 21 & 60 & mid cad & 3 & mammal & unid & & & absent & wh & & 0.1 & fine screen \\
\hline U 21 & 70 & mid cad & 1 & lg mam & unid & & & absent & char & & 0.2 & fine screen \\
\hline U 21 & Oto10 & mid cad & 1 & Ig mam & I.b.frag & & & absent & wh & & 0.4 & \\
\hline U 21 & Oto10 & mid cad & 1 & med art & \multicolumn{2}{|c|}{ mtpod shft frg } & & abrade,exf & not & & 1 & \\
\hline U 21 & 20 to 30 & mid cad & 10 & mammal & unid & & & absent & wh & & 0.3 & \\
\hline U 21 & 30 to 40 & mid cad & 1 & lg mam & I.b.frag & & & absent & char & & 0.5 & \\
\hline U 21 & 30 to 40 & mid cad & 1 & lg mam & alveolar frg & & & abrade & not & & 0.3 & \\
\hline U 21 & 30 to 40 & mid cad & 2 & Ig mam & unid & & & abrade & not & & 0.3 & \\
\hline U 21 & 30 to 40 & mid cad & 1 & lg mam & I.b.frag & & & exfol & not & & 0.3 & \\
\hline U 21 & 30 to 40 & mid cad & 1 & mammal & unid & & & absent & wh & & 0.1 & \\
\hline U 21 & 30 to 40 & mid cad & 1 & med art & hum dist & $R$ & & abrade & not & rodent & 34.2 & sev gnaw \\
\hline U 21 & 30 to 40 & mid cad & 1 & med art & \multicolumn{2}{|c|}{ mtpod shft frg } & & exfol & not & & 1 & \\
\hline U 21 & 40 to 50 & mid cad & 2 & lg mam & I.b.frag & & & absent & not & rodent & 5.5 & \\
\hline U 21 & 40to50 & mid cad & 7 & lg mam & unid & & & abrade & not & & 0.9 & \\
\hline U 21 & 40 to 50 & mid cad & 1 & med art & rad shft frg & & & absent & not & rodent & 12.1 & \\
\hline U 21 & 50 to60 & mid cad & 8 & Ig mam & unid & & & absent & blk & & 1.2 & \\
\hline U 21 & 50 to 60 & mid cad & 1 & lg mam & unid & & & abrade & not & & 0.2 & \\
\hline U 21 & 50 to 60 & mid cad & 6 & lg mam & unid & & & absent & wh & & 1.1 & \\
\hline U 21 & 50 to 60 & mid cad & 3 & lg mam & unid & & & absent & wh & & 2.2 & \\
\hline U 21 & 50 to 60 & mid cad & 1 & med art & \multicolumn{2}{|c|}{ mtpod shft frg } & & abrade.exf: & not & rodent & 1.4 & \\
\hline U 21 & 50 to 60 & mid cad & 1 & med art & mtpod $p x$ & & $\mathrm{imm}$ & absent & wh & & 1.5 & unfused \\
\hline U 21 & 50 to 60 & mid cad & 1 & med art & \multicolumn{2}{|c|}{ mtpod condyle } & & absent & blk & & 2.9 & \\
\hline U 21 & 50 to60 & mid cad & 4 & med art & \multicolumn{2}{|c|}{ mtpod cond frg } & & abrade & wh & & 2.2 & \\
\hline U 21 & 50 to 60 & mid cad & 3 & med art & \multicolumn{2}{|c|}{ mtpod shft frg } & & absent & wh & & 2.8 & \\
\hline U 21 & 50 to 60 & mid cad & 7 & unid & unid & & & absent & wh & & 1 & \\
\hline U 21 & 60 to 70 & mid cad & 5 & lg mam & I.b.frag & & & abrade,exfi & not & & 3.1 & \\
\hline U 21 & 60 to 70 & mid cad & 10 & Ig mam & unid & & & abrade,exfi & inot & & 1.7 & \\
\hline U 21 & 60 to 70 & mid cad & 2 & lg mam & unid & & & absent & wh & & 0.6 & \\
\hline U 21 & 60 to 70 & mid cad & 1 & med art & \multicolumn{2}{|l|}{ nav-cuboid L } & & abrade,exf & char & & 2.6 & \\
\hline U 21 & 60 to 70 & mid cad & 1 & med art & petrous & $\mathbf{R}$ & & abrade,exfi & char & & 3.7 & \\
\hline U 21 & 60 to 70 & mid cad & 1 & med art & mttar prox & $\mathbf{R}$ & & abrade, exfi & not & & 3 & \\
\hline U 22 & 10 to 20 & mid cad & 5 & Ig mam & unid & & & abrade & wh & & 1 & \\
\hline U 22 & 20 to 30 & mid cad & 4 & lg mam & unid & & & abrade & wh & & 1 & \\
\hline U 22 & 20 to 30 & mid cad & 2 & lg mam & unid & & & absent & wh & & 0.6 & \\
\hline
\end{tabular}




\begin{tabular}{|c|c|c|c|c|c|c|c|c|c|}
\hline \multirow{2}{*}{$\begin{array}{l}\text { U } 22 \\
122\end{array}$} & $30 t 040$ & mid cad & 1 & lg mam & I.b.frag & & abrade,exfichar & & 0.5 \\
\hline & 30 to 40 & mid cad & 1 & Ig mam & unid & & abrade,exfichar & & 0.7 \\
\hline U 22 & 30 to 40 & mid cad & 1 & lg mam & l.b.frag & & absent & & 0.3 \\
\hline U 22 & 40 to 50 & mid cad & 2 & Ig mam & I.b.frag & & abrade, exfinot & rodent & 5.9 \\
\hline$\cup 22$ & 40 to 50 & mid cad & 6 & Ig mam & unid & & abrade,exfi not & & 2.7 \\
\hline U 22 & 40 to 50 & mid cad & 4 & Ig mam & I.b.frag & & absent & & 1.8 \\
\hline U 22 & 40 to 50 & mid cad & 1 & med art & rad shft frg & & abrade, exfi not & rodent & 2.5 \\
\hline U 22 & 40 to50 & mid cad & 1 & med art & tib prox frg $R$ & & abrade, exfinot & & 2.7 \\
\hline U 22A & Oto10 & mid cad & 1 & lg mam & unid & & abrade,exfinot & & 0.1 \\
\hline U 22A & Oto10 & mid cad & 1 & Ig mam & unid & & absent & & 0.2 \\
\hline U 22A & Oto10 & mid cad & 1 & med art & mtpod shft frg & & absent & & 1.2 \\
\hline U 22A & 10 to 20 & mid cad & 11 & Ig mam & I.b.frag & & exfol & & 1.7 \\
\hline U 22A & 10 to 20 & mid cad & 1 & med art & mtpod shft frg & & absent & & 0.6 \\
\hline U 22A & 30 to 40 & mid cad & 3 & lg mam & unid & & abrade,exfinot & & 3.4 \\
\hline U 22A & 30 to 40 & mid cad & 3 & Ig mam & unid & & absent & & 0.7 \\
\hline U 22A & 40 to 50 & mid cad & 2 & lg mam & unid & & abrade,exfinot & & 4.6 \\
\hline U 22A & 40 to 50 & mid cad & 1 & lg mam & I.b.frag & & etch light not & & 0.9 \\
\hline U 22A & 40 to 50 & mid cad & 5 & mammal & unid & & absent & & 0.4 \\
\hline U22\&.22A & 50 to 60 & mid cad & 4 & deer & tooth frg & $\mathrm{imm}$ & absent & & 0.6 \\
\hline U22\&.22A & $50 t 060$ & mid cad & 4 & mammal & unid & & absent & & 0.2 \\
\hline U222822A & 50 to60 & mid cad & 1 & med art & calc dist & & abrade, exfinot & & 3.8 \\
\hline U22822A & 50 to60 & mid cad & 1 & med art & mand cond $R$ & & absent & & 1 \\
\hline U22\&22A & 50 to 60 & mid cad & 1 & turtle & shell frg & & absent & & 0.1 \\
\hline
\end{tabular}


Appendix 3, OCR Data Forms 


\section{BIBLIOGRAPHY}

Burt, William H. and Richard P. Grossenheider

1980 A Field Guide to the Mammals. Peterson Field Guide Series, edited by R. T. Peterson, 3rd edition, Houghton Mifflin Co., Boston.

Gilbert, B. M.

1980 Mammalian Osteology. Revised from Mammalian Osteo- Archaeology: North America (Missouri Archaeology Society). B. M. Gilbert, Publisher, Laramie.

Munzel, S.

1986 Quantitative Analysis and the Reconstruction of Site Patterning. Paper presented at the Vth International Conference of the International Council for ArchaeoZoology, Aug. 25-30, Bordeaux.

Olsen, S.J.

1964 Mammal Remains from Archaeological Sites, Part I: Southeastern and Southwestern United States. Papers of the Peabody Museum of Archaeology and Ethnology, Harvard University, Cambridge. Vol.56(1).

Schmid, Elizabeth

1972 Atlas of Animal Bones. Elsevier Publishing, Amsterdam. 
Table 1

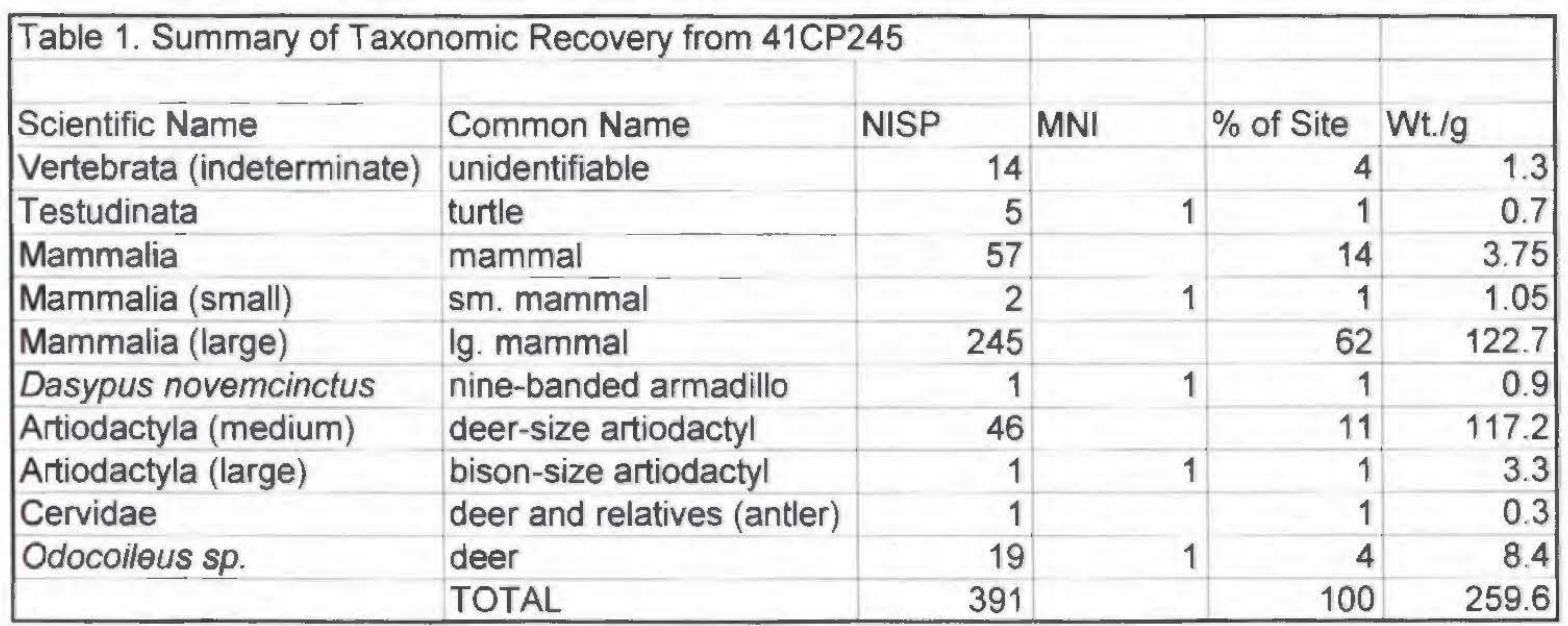


Table 2

\begin{tabular}{|c|c|c|c|c|c|c|c|}
\hline & & & & & & & \\
\hline \multirow{3}{*}{ Scientific Name } & Common Name & Element & & & & & \\
\hline & & & & & long & podials & \\
\hline & & unid & teeth & cranial & bones & $\& \mathrm{phx}$ & other \\
\hline Vertebrata (indeterminate) & unidentifiable & 14 & & & & & \\
\hline Testudinata & turtle & & & & & & 5 \\
\hline Mammalia & mammal & 57 & & & & & \\
\hline Mammalia (small) & sm. mammal & & & & 2 & & \\
\hline Mammalia (large) & lg. mammal & 183 & 3 & 2 & 56 & 1 & \\
\hline Dasypus novemcinctus & nine-banded armadillo & & & & 1 & & \\
\hline Artiodactyla (medium) & deer-size artiodactyl & & & 9 & 29 & 8 & \\
\hline Artiodactyla (large) & bison-size artiodactyl & & & & 1 & & \\
\hline Cervidae & deer and relatives (antler) & & & & & & 1 \\
\hline \multirow[t]{2}{*}{ Odocoileus sp. } & deer & & 19 & & & & \\
\hline & TOTAL & 254 & 22 & 11 & 89 & 9 & 6 \\
\hline \multicolumn{8}{|l|}{ NOTE: } \\
\hline \multicolumn{8}{|c|}{ "Teeth" inc. enamel fragments as well as complete teeth. } \\
\hline \multirow{2}{*}{\multicolumn{8}{|c|}{$\begin{array}{l}\text { "Cranial" inc. skull elements, mandible, and maxilla fragments. } \\
\text { "Long Bones" inc. fragments as well as complete lona bones. }\end{array}$}} \\
\hline & & bones. & & & & & \\
\hline \multicolumn{8}{|c|}{ "Podials \& phx" inc. extreme lower leg bones. } \\
\hline "Other" inc. antler and turtle & shell fragments. & & & & & & \\
\hline
\end{tabular}




\begin{tabular}{|c|c|c|c|c|c|c|c|}
\hline \multirow[t]{2}{*}{ Scientific Name } & \multirow[t]{2}{*}{ Common Name } & \multicolumn{2}{|c|}{ Taphonomy } & \multirow[b]{2}{*}{ abraded } & \multirow[b]{2}{*}{ exfoliated } & \multirow[b]{2}{*}{ abrade\&exfol } & \multirow[b]{2}{*}{ humic stain } \\
\hline & & absent & root etch & & & & \\
\hline Vertebrata (indeterminate) & unidentifiable & 14 & & & & & \\
\hline Testudinata & turtle & 5 & & & & & \\
\hline Mammalia & mammal & 35 & & 5 & & 17 & \\
\hline Dasypus novemcinctus & nine-banded armadillo & & & & & & 1 \\
\hline Artiodactyla (medium) & deer-size artiodactyl & 11 & 7 & 8 & 2 & 18 & \\
\hline Artiodactyla (large) & bison-size artiodactyl & & & & & 1 & \\
\hline Cervidae & deer and relatives (antler) & 1 & & & & & \\
\hline Odocoileus sp. & deer & 19 & & & & & \\
\hline
\end{tabular}


Table 4

\begin{tabular}{|c|c|c|c|c|c|}
\hline \multirow{2}{*}{ Scientific Name } & \multirow{2}{*}{ Common Name } & \multicolumn{2}{|c|}{ Degree of Burning } & \multirow[b]{2}{*}{ black } & \multirow[b]{2}{*}{ white } \\
\hline & & not burn & charred & & \\
\hline Vertebrata (indeterminate) & unidentifiable & & & & 14 \\
\hline Testudinata & turtle & 1. & 1 & & 3 \\
\hline Mammalia & mammal & 21 & 3 & & 33 \\
\hline Mammalia (small) & sm. mammal & 1 & & & 1 \\
\hline Mammalia (large) & Ig. mammal & 159 & 16 & 11 & 59 \\
\hline Dasypus novemcinctus & nine-banded armadillo & 1 & & & \\
\hline Artiodactyla (medium) & deer-size artiodactyl & 30 & 2 & 1 & 13 \\
\hline Artiodactyla (large) & bison-size artiodactyl & 1. & & & \\
\hline Cervidae & deer and relatives (antler) & & & & 1 \\
\hline Odocoileus sp. & deer & 19 & & & \\
\hline & TOTAL & 233 & 22 & 12 & 124 \\
\hline
\end{tabular}




\begin{tabular}{|c|c|c|c|c|c|c|c|c|c|c|c|c|c|c|c|}
\hline \multicolumn{16}{|c|}{ Table 5. Distribution of Burned Faunal Specimens from $41 \mathrm{CP} 245$} \\
\hline Context & Scientific Name & Common Name & Provenie & ence and & Depth (cr & embs) & & & & & & & & & \\
\hline \multirow{9}{*}{ Early Caddo } & doan (bum $=15$ ) & & ST3 & ST8 & ST15 & ST17 & ST20 & U 21 & & & & & & & \\
\hline & & & $80 t 0100$ & $80 t 0100$ & $70 t 090$ & 70 to 80 & 70 to 80 & $70 t 0100$ & & & & & & & \\
\hline & Vertebrata (indeterminate) & unidentifiable & & & 1 & & & & & & & & & & \\
\hline & Testudinata & turtle. & 1. & & $\longrightarrow$ & & & 1 & & & & & & &.- \\
\hline & Mammalia & mammal & & & & & 1 & & & & & & & & \\
\hline & Mammalia (large) & Ig. mammal & & 1 & 1 & 1 & & 7 & & & & & & & \\
\hline & Cervidae & deer and relatives (antler) & & & & & & 1 & & & & & & & \\
\hline & & TOTAL & 1 & 1 & 2. & 1 & 1 & 9 & & & & & & & \\
\hline & & & & & & & & & & & & & & & \\
\hline \multirow{2}{*}{\multicolumn{2}{|c|}{ Early/Middle Caddoan (burn=2) }} & & ST2 & ST3 & & & & & & & & & & & \\
\hline & & & $60 t 080$ & 60 to80 & & & & & & & & & & & \\
\hline & Mammalia (large) & Ig. mammal & 1 & 1 & & & & & & & & & & & \\
\hline \multicolumn{2}{|c|}{ Middle Caddoan (bum $=141$ ) } & & Feat1 & ST2 & ST6 & ST15 & ST17 & ST18 & ST 19 & ST20 & & & & & \\
\hline Midone Lac & 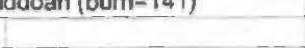 & & Oto40 & 0 to60 & $40 t 060$ & 10 to 70 & Oto50 & $10 t 060$ & 01070 & 201040 & Oto70 & Oto 70 & 10 to 50 & 0 to50 & 501060 \\
\hline & Vertebrata (indeterminate) & unidentifiable & : & & & & & & & & & 13 & & & \\
\hline & Testudinata & turtle & & & & & & & & & & 1. & & & 1 \\
\hline & Mammalia & mammal & & 2 & & & 1 & & 1 & & 5 & 17. & & 5 & 4 \\
\hline & Mammalia (small) & sm. mammal & & & & & & & & & & 1 & & & \\
\hline & Marnmalia (large) & g. mammal & 1. & 3 & 1 & 2. & 1 & 4 & 6 & 1 & 9 & 23. & 18 & 5 & \\
\hline & Artiodactyla (medium) & deer-size artiodacty! & & & & & & 1 & & & & 12 & & 2 & 1 \\
\hline & & TOTAL & 1 & 5 & 1 & 2 & 2 & 5 & 7 & 1 & 14 & 67 & 18 & 12 & 6 \\
\hline
\end{tabular}


Table 6

\begin{tabular}{|c|c|c|c|c|c|c|c|c|c|}
\hline Context & Scientific Name & Common Name & Provenic & ence and & Depth (Cr & mbs) & & & \\
\hline Early Cac & doan & & Unit 21 & Unit 21 & Unit 21 & & & & \\
\hline$(g n a w=4)$ & & & 70 to 80 & 80 to 90 & 90to100 & & & & \\
\hline & Mammalia (large) & lg. mammal & 1 & 1 & 1 & & & & \\
\hline & Artiodactyla (medium) & deer-size artiodactyl & & 1 & & & & & \\
\hline Early/Mid & dlle Caddoan & & & & & & & & \\
\hline$(g n a w=1)$ & & & 60 to 80 & & & & & & \\
\hline & Mammalia (large) & Ig. mammal & 1 & & & & & & \\
\hline Middle C & addoan & & Feat 1 & ST 1 & ST 17 & ST 18 & Unit 1 & Unit 21 & Unit 22 \\
\hline (gnaw $=16$ & & & Oto40 & 40 to60 & 20 to 30 & 50 to60 & $50 \operatorname{to} 60$ & 30 to 60 & 40 to50 \\
\hline & Mammalia (large) & Ig. mammal & 3 & 1 & 1 & 1 & & 2 & 2 \\
\hline & Artiodactyla (medium) & deer-size artiodactyl & & & & & 1 & 4 & 1 \\
\hline
\end{tabular}


Table 7

\begin{tabular}{|c|c|c|c|c|}
\hline \multirow[t]{2}{*}{ Scientific Name } & Common Name & Context & & \\
\hline & & Early Caddoan & Early/Mid Caddoan & Middle Caddoan \\
\hline Vertebrata (indeterminate) & unidentifiable & 1 & & 13 \\
\hline Testudinata & turtle & 2 & & 3 \\
\hline Mammalia & mammal & 21 & & 36 \\
\hline Mammalia (small) & sm. mammal & & & 2 \\
\hline Mammalia (large) & Ig. mammal & 57 & 3 & 185 \\
\hline Dasypus novemcinctus & nine-banded armadillo & & & 1 \\
\hline Artiodactyla (medium) & deer-size artiodactyl & 7 & & 39 \\
\hline Artiodactyla (large) & bison-size artiodactyl & & & 1 \\
\hline Cervidae & deer and relatives (antler) & 1 & & \\
\hline \multirow[t]{2}{*}{ Odocoileus sp. } & deer & 6 & & 13 \\
\hline & TOTAL & 95 & 3 & 293 \\
\hline
\end{tabular}




\begin{tabular}{|c|c|c|c|c|c|c|c|c|c|c|c|c|c|c|c|c|c|}
\hline Vertebrata (indeterminate) & unidentifiable & & & & & & & 1 & & & & & & 13 & & & \\
\hline Testudinata & turtle & & & 1 & 1 & & & & & & & & & 2 & & & 1 \\
\hline Mammalia (small) & sm. mammal & & & & & & & & & & & & 1 & 1 & & & \\
\hline Mammalia (large) & Ig. mammal & 19 & 1 & 12 & 2 & 1 & 1 & 6 & 4 & 4 & 15 & 1 & 31 & 110 & 26 & 12 & \\
\hline Dasypus novemcinctus & nine-banded armadillo & & & 1 & & & & & & & & & & & & & \\
\hline Cervidae & deer and relatives (antler) & & & & & & & & & & & & & 1 & & & \\
\hline \multirow[t]{2}{*}{ Odocoileus sp. } & deer & & & & & & & 5 & & & & 1 & & 9 & & & 4 \\
\hline & TOTAL & 22 & 1 & 16 & 8 & 1. & 1 & 12 & 5 & 5 & 16 & 3 & 40 & 203 & 28 & 19 & 11 \\
\hline
\end{tabular}


Table 9

\begin{tabular}{|c|c|c|c|c|c|c|c|c|c|c|c|c|c|c|c|c|c|}
\hline Table 9. & Distribution of $41 \mathrm{CP} 245 \mathrm{Fau}$ & unal Specimens & & & & & & & & & & & & & & & \\
\hline Context & Scientific Name & Common Name & Provenie & ence and & Depth (c & cmbs) & & & & & & & & & & & \\
\hline Early Cad & ddoan $(N=95)$ & & ST3 & ST8 & ST15 & ST17 & ST19 & ST20 & U 1 & U 21 & & & & & & & \\
\hline & & & 8010100 & 8010100 & 70 to 90 & $70 t 080$ & 80 to90 & 701080 & 85 . & 70 to 100 & & & & & & & \\
\hline & Vertebrata (indeterminate) & unidentifiable & & & 1 & & & & - & & & & & & & & \\
\hline & Testudinata & turtle & 1 & 1 & & & & & & 1 & & & & & & & \\
\hline & Mammalia & mammal & 3 & & & & 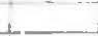 & $\overline{1}$ & & 17 & & & & & & & \\
\hline & Mammalia (large) & lg. mammal & & 1 & 2 & 1 & 1 & & 3. & 49 & & & & & & & \\
\hline & Artiodactyla (medium) & deer-size artiodactyl & & & & & 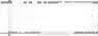 & & & 7 & & & & & & & \\
\hline & Cervidae & deer and relatives (antler) & & & & & & & & 1 & & & & & & & \\
\hline & Odocolleus sp. & deer & 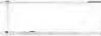 & & 5 & & . & & . & 1 & & & & & & & \\
\hline & & TOTAL & 4 & 1 & 8 & 1 & 1 & 1 & 3 & 76 & & & & & & & \\
\hline & & & & & & & & & & & & & & & & $i$ & i \\
\hline Early/Mid & ddle Caddoan $(\mathrm{N}=3)$ & & ST2 & ST3 & & & & & & & & & & & & & \\
\hline & & & 601080 & $60 t 080$ & & & & & & & & & & & & & \\
\hline & Mammalia (large) & Ig. mammal & 2 & 1 & & & & & & & & & & & & & \\
\hline Middle $\mathrm{C}$ & Caddoan $(\mathrm{N}=293)$ & & Feat1 & ST1 & ST2 & ST3 & ST6 & ST15 & ST17: & ST18 & ST19 & ST20 & U1 & U 21 & บ 22 & U $22 a$ & U $22822 a$ \\
\hline & & & 0 to 40 & $40 t 060$ & $0 t 060$ & 20 to 40 & 40 to60 & $10 t 070$ & 0 to50 & 10to60 & Oto 70 & 20 to 40 & 01070 & 0to 70 & $10 t 050$ & Oto5o & 50 to60 \\
\hline & Vertebrata (indeterminate) & unidentifiable & & & & & & & & & & & & 13 & & & \\
\hline & Testudinata & turtle & & & 1 & & & & & & & & & 1 & 1 & & 1 \\
\hline & Mammalia & mammal & & & 2 & & & & 1 & & 1 & & 5 & 18 & & 5 & 4 \\
\hline & Mammalia (small) & sm. mammal & * & & & & & & & & & & 1 & 1 & 1 & & \\
\hline & Mammalia (large) & lg. mammal & 19 & 1. & 10 & 1 & 1 & 4 & 3 & 4 & 14 & 1 & 28 & 61 & 26 & 12. & \\
\hline & Dasypus novemcinctus & nine-banded armadillo & & & 1 & & & & & & & & & & & & \\
\hline & Artiodactyla (medium) & deer-size artiodactyl & 2 & & & 2 & & & & 1 & & & 3 & 25 & 2 & 2 & 2 \\
\hline & Artiodactyla (large) & bison-size artiodactyl & 1 & & & & & & & & & & & $i$ & & & \\
\hline & Odacoileus sp. & deer & & & & & & & 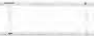 & & & 1 & & 8 & 8 & & 4 \\
\hline & & TOTAL & 22 & 1 & 14 & 3 & 1 & 4 & 4 & 5 & 15 & 2 & 37 & 127 & 28 & 19 & 11 \\
\hline
\end{tabular}




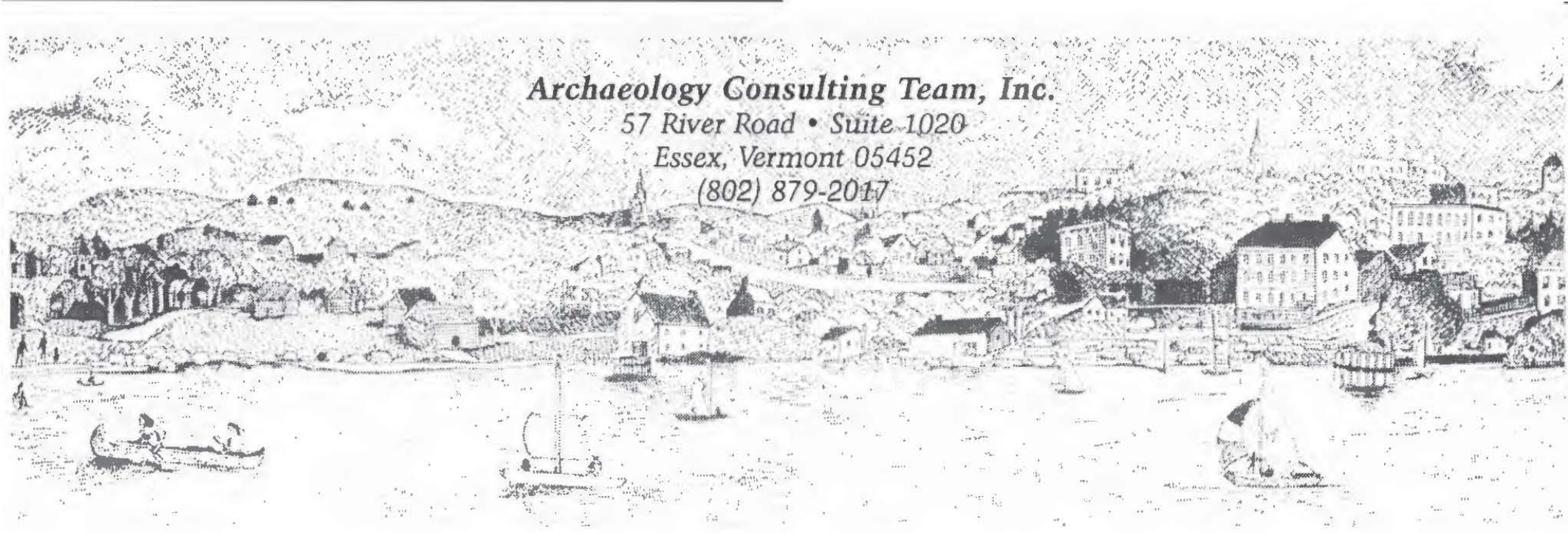

June 26,2000

Mr. Bo Nelson

344CR 4154

Pittsburg, TX 75686

Dear Mr. Nelson:

Thank you for sending us the soil samples from 41-CP-245 for OCR DATE analyses. These samples were received on May 30,2000, in moist condition. Prior to our analyses, we screened the samples through a $2 \mathrm{~mm}$-meshed screen to remove any cultural material. This material is being returned to you for further analyses. The OCR DATE analyses were conducted in accordance with the procedures outlined in:

Frink, D. 1992 The Chemical Variability of Carbonized Organic Matter Through Time. Archaeology of Eastern North America, Vol. 20:67-79.

using the data format and formula as presented in:

Frink, D. 1994 The Oxidizable Carbon Ratio (OCR): A Proposed Solution to Some of the Problems Encountered with Radiocarbon Data. North American Archaeologist. Vol.15 (\#1). 
The results of the OCR analyses for your samples are presented on the separate computer printouts. The bottom line OCR $\mathrm{OATE}_{\mathrm{DA}}$ and the confidence intervals have been rounded to the nearest year. Also, the expression of results has been adjusted to "years before present" -defined as 1950 , to correspond with ${ }^{14} \mathrm{C}$ radiocarbon data. For example, your sample from $60 \mathrm{~cm}$ (ACT \#4542) should read OCR DATE: $765 \pm 22$ YAP. Further rounding may be prudent (egg., $765 \pm 25$ YBP).

I hope that the OCR $R_{\text {DATE }}$ data provided will be helpful in your evaluation of this site. If you have further questions on the OCR procedure, please don't hesitate to give us a call. To aid us in improving this dating technique, we would appreciate it if you would send us information on how the OCR samples.

Also please feel free to keep track of the OCR literature and data on our WEBSite: http://members.aol.com/dsfrink/ocr/ocrpage.htm

Sincerely,

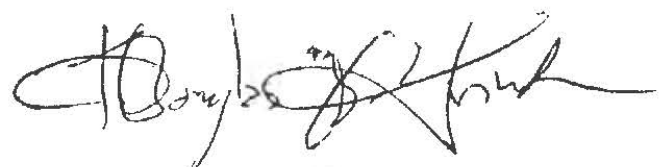

Douglas S. Fink

cc: Dr. Tim Perttula 


\section{Calculated OCR DATE Report}

\section{For Archeological \& Environmental C}

22-Jun-00

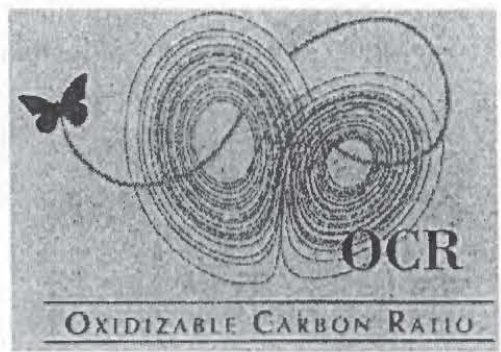

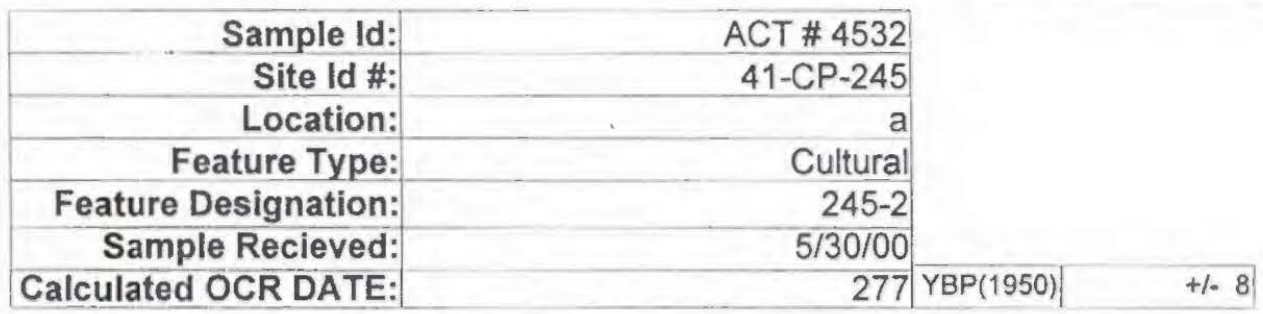

\begin{tabular}{|c|c|}
\hline Sample Id: & ACT \# 4533 \\
\hline Site Id \#: & $41-\mathrm{CP}-245$ \\
\hline Location: & a \\
\hline Feature Type: & Cultural \\
\hline Feature Designation: & $245-3$ \\
\hline Sample Recieved: & $5 / 30 / 00$ \\
\hline Calculated OCR DATE: & $402 \mid \mathrm{YBP}(1950)$ \\
\hline
\end{tabular}

\begin{tabular}{|c|c|}
\hline Sample Id: & ACT \# 4534 \\
\hline Site Id \#: & 41-CP-245 \\
\hline Location: & a \\
\hline Feature Type: & Cultural \\
\hline Feature Designation: & $245-4$ \\
\hline Sample Recieved: & $5 / 30 / 00$ \\
\hline Calculated OCR DATE: & 438 YBP $(1950)$ \\
\hline
\end{tabular}

\begin{tabular}{|c|c|}
\hline Sample Id: & ACT\# 4535 \\
\hline Site Id \#: & 41-CP-245 \\
\hline Location: & a \\
\hline Feature Type: & Cultural \\
\hline Feature Designation: & $245-5$ \\
\hline Sample Recieved: & $5 / 30 / 00$ \\
\hline Calculated OCR DATE: & 545 YBP(1950) \\
\hline
\end{tabular}




\section{Calculated OCR DATE Report}

\section{For Archeological \& Environmental C}

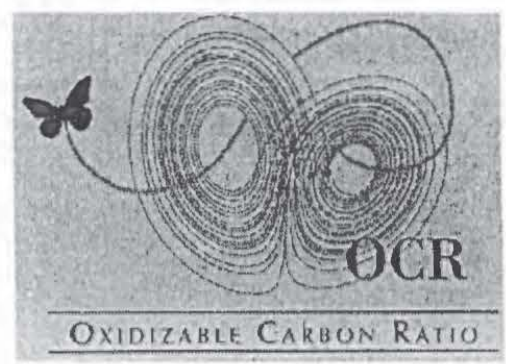

\begin{tabular}{|c|c|c|}
\hline Sample Id: & ACT \# 4536 & \\
\hline Site Id \#: & $41-\mathrm{CP}-245$ & \\
\hline Location: & a & \\
\hline Feature Type: & Cultural & \\
\hline Feature Designation: & $245-6$ & \\
\hline Sample Recieved: & $5 / 30 / 00$ & \\
\hline Calculated OCR DATE: & $584|\mathrm{YBP}(1950)|$ & $+1-17$ \\
\hline
\end{tabular}

\begin{tabular}{|c|c|}
\hline Sample Id: & ACT \# 4537 \\
\hline Site Id \#: & $41-\mathrm{CP}-245$ \\
\hline Location: & a \\
\hline Feature Type: & Cultural \\
\hline Feature Designation: & $245-7$ \\
\hline Sample Recieved: & $5 / 30 / 00$ \\
\hline Calculated OCR DATE: & 587 YBP(1950) \\
\hline
\end{tabular}

\begin{tabular}{|c|c|}
\hline Sample Id: & ACT \# 4538 \\
\hline Site Id \#: & $41-\mathrm{CP}-245$ \\
\hline Location: & a \\
\hline Feature Type: & Cultural \\
\hline Feature Designation: & $245-8$ \\
\hline Sample Recieved: & $5 / 30 / 00$ \\
\hline Calculated OCR DATE: & 550 YBP(1950) \\
\hline
\end{tabular}

\begin{tabular}{|r|r|}
\hline Sample Id: & ACT \# 4539 \\
\hline Site Id \#: & $41-$ CP-245 \\
\hline Location: & a \\
\hline Feature Type: & Cultural \\
\hline Feature Designation: & $245-9$ \\
\hline Sample Recieved: & $5 / 30 / 00$ \\
\hline Calculated OCR DATE: & 588 \\
\hline
\end{tabular}




\section{Calculated OCR DATE Report \\ For Archeological \& Environmental C}

22-Jun-00

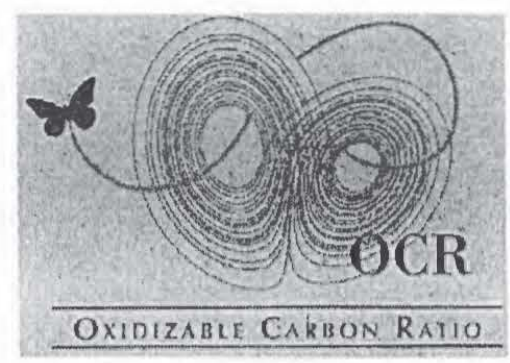

\begin{tabular}{|c|c|}
\hline Sample Id: & ACT \# 4540 \\
\hline Site Id \#: & $41-C P-245$ \\
\hline Location: & a \\
\hline Feature Type: & Cultural \\
\hline Feature Designation: & $245-10$ \\
\hline Sample Recieved: & $5 / 30 / 00$ \\
\hline Calculated OCR DATE: & 679 YBP (1950) \\
\hline
\end{tabular}

\begin{tabular}{|c|c|}
\hline Sample Id: & ACT \# 4541 \\
\hline Site Id \#: & 41-CP-245 \\
\hline Location: & a \\
\hline Feature Type: & Cultural \\
\hline Feature Designation: & $245-11$ \\
\hline Sample Recieved: & $5 / 30 / 00$ \\
\hline Calculated OCR DATE: & 786 YBP (1950) \\
\hline
\end{tabular}

\begin{tabular}{|r|r|}
\hline Sample Id: & ACT \# 4542 \\
\hline Site Id \#: & $41-C P-245$ \\
\hline Location: & a \\
\hline Feature Type: & Cultural \\
\hline Feature Designation: & $245-12$ \\
\hline Sample Recieved: & $5 / 30 / 00$ \\
\hline Calculated OCR DATE: & 765 \\
\hline
\end{tabular}

\begin{tabular}{|c|c|}
\hline Sample Id: & ACT \# 4543 \\
\hline Site Id \#: & $41-\mathrm{CP}-245$ \\
\hline Location: & a \\
\hline Feature Type: & Cultural \\
\hline Feature Designation: & $245-13$ \\
\hline Sample Recieved: & $5 / 30 / 00$ \\
\hline Calculated OCR DATE: & $767 \mid Y B P(1950)$ \\
\hline
\end{tabular}




\section{Calculated OCR DATE Report}

\section{For Archeological \& Environmental C}

22-Jun-00

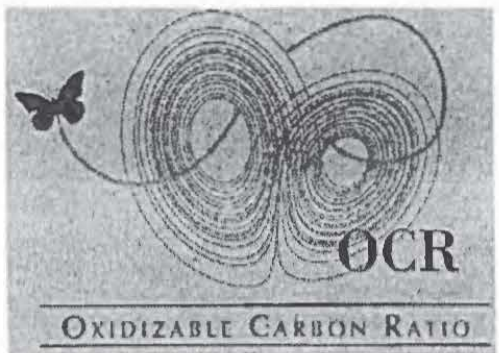

\begin{tabular}{|c|c|}
\hline Sample Id: & ACT \# 4544 \\
\hline Site Id \#: & $41-\mathrm{CP}-245$ \\
\hline Location: & a \\
\hline Feature Type: & Cultural \\
\hline Feature Designation: & $245 / 14$ \\
\hline Sample Recieved: & $5 / 30 / 00$ \\
\hline Calculated OCR DATE: & $1103 \mathrm{YBP}(1950)$ \\
\hline
\end{tabular}

\begin{tabular}{|c|c|c|}
\hline Sample Id: & ACT \# 4545 & \\
\hline Site Id \#: & $41-\mathrm{CP}-245$ & \\
\hline Location: & $a$ & \\
\hline Feature Type: & Cultural & \\
\hline Feature Designation: & $245-15$ & \\
\hline Sample Recieved: & $5 / 30 / 00$ & \\
\hline Calculated OCR DATE: & 1108 YBP(1950) & $+1-33$ \\
\hline
\end{tabular}

\begin{tabular}{|r|r|}
\hline Sample Id: & ACT \# 4546 \\
\hline Site Id \#: & $41-$ CP-245 \\
\hline Location: & $a$ \\
\hline Feature Type: & Cultural \\
\hline Feature Designation: & $245-16$ \\
\hline Sample Recieved: & $5 / 30 / 00$ \\
\hline Calculated OCR DATE: & 1109 \\
\hline
\end{tabular}

\begin{tabular}{|c|c|}
\hline Sample Id: & ACT \# 4547 \\
\hline Site Id \#: & $41-C P-245$ \\
\hline Location: & a \\
\hline Feature Type: & Cultural \\
\hline Feature Designation: & $245-17$ \\
\hline Sample Recieved: & $5 / 30 / 00$ \\
\hline Calculated OCR DATE: & 1102 YBP(1950) \\
\hline
\end{tabular}




\section{Calculated OCR DATE Report}

\section{For Archeological \& Environmental C}

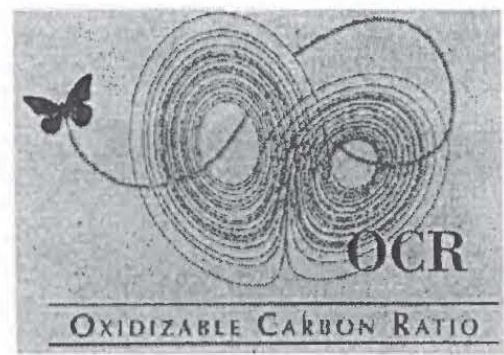

\begin{tabular}{|r|r|}
\hline Sample Id: & ACT \# 4548 \\
\hline Site Id \#: & $41-$ CP-245 \\
\hline Location: & Cultural \\
\hline Feature Type: & $245-18$ \\
\hline Feature Designation: & $5 / 30 / 00$ \\
\hline Sample Recieved: & 1160 \\
\hline Calculated OCR DATE: & YBP(1950) \\
\hline
\end{tabular}

\begin{tabular}{|c|c|c|c|}
\hline Sample Id: & ACT \# 4549 & & \\
\hline Site Id \#: & $41-C P-245$ & & \\
\hline Location: & a & & \\
\hline Feature Type: & Cultural & & \\
\hline Feature Designation: & $245-19$ & & \\
\hline Sample Recieved: & $5 / 30 / 00$ & & \\
\hline Calculated OCR DATE: & 1241 & YBP(1950) & $+1-37$ \\
\hline
\end{tabular}

\begin{tabular}{|r|r|}
\hline Sample Id: & ACT \# 4550 \\
\hline Site Id \#: & $41-$ CP-245 \\
\hline Location: & Cultural \\
\hline Feature Type: & $245-20$ \\
\hline Feature Designation: & $5 / 30 / 00$ \\
\hline Sample Recieved: & 1445 \\
\hline Calculated OCR DATE: & YBP $(1950)$ \\
\hline$+/ 43$ \\
\hline
\end{tabular}

\begin{tabular}{|r|r|}
\hline Sample Id: & ACT\# 4551 \\
\hline Site Id \#: & $41-C P-245$ \\
\hline Location: & $a$ \\
\hline Feature Type: & Cultural \\
\hline Feature Designation: & $245-22$ \\
\hline Sample Recieved: & $5 / 30 / 00$ \\
\hline Calculated OCR DATE: & 1596 \\
\hline
\end{tabular}




\section{Calculated OCR DATE Report}

\section{For Archeological \& Environmental C}

22-Jun-00

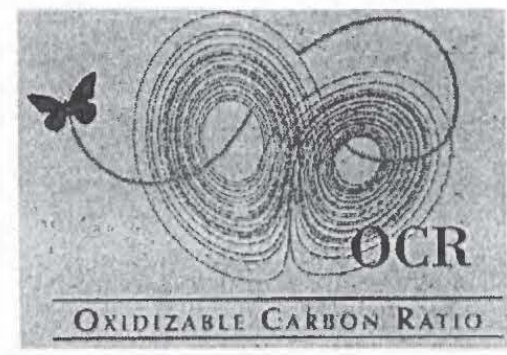

\begin{tabular}{|c|c|c|}
\hline Sample Id: & ACT \# 4552 & \\
\hline Site Id \#: & 41-CP-245 & \\
\hline Location: & a & \\
\hline Feature Type: & Cultural & \\
\hline Feature Designation: & $245-21$ & \\
\hline Sample Recieved: & $5 / 30 / 00$ & \\
\hline Calculated OCR DATE: & 1682 & YBP(1950) \\
\hline
\end{tabular}

\begin{tabular}{|c|c|c|}
\hline Sample Id: & ACT \# 4553 & \\
\hline Site Id \#: & $41-C P-245$ & \\
\hline Location: & a & \\
\hline Feature Type: & Cultural & \\
\hline Feature Designation: & $245-23$ & \\
\hline Sample Recieved: & $5 / 30 / 00$ & \\
\hline Calculated OCR DATE: & 1856 YBP(1950) & $+1-55$ \\
\hline
\end{tabular}

\begin{tabular}{|r|r|}
\hline Sample Id: & ACT \# 4554 \\
\hline Site Id \#: & $41-$ CP-245 \\
\hline Location: & Cultural \\
\hline Feature Type: & $245-24$ \\
\hline Feature Designation: & $5 / 30 / 00$ \\
\hline Sample Recieved: & 1908 \\
\hline Calculated OCR DATE: & YBP(1950) \\
\hline
\end{tabular}

\begin{tabular}{|r|r|}
\hline Sample Id: & ACT \# 4555 \\
\hline Site Id \#: & $41-$ CP-245 \\
\hline Location: & Cultural \\
\hline Feature Type: & $245-25$ \\
\hline Feature Designation: & $5 / 30 / 00$ \\
\hline Sample Recieved: & 2499 \\
\hline Calculated OCR DATE: & \\
\hline
\end{tabular}




\section{Calculated OCR DATE Report}

\section{For Archeological \& Environmental C}

22-Jun-00

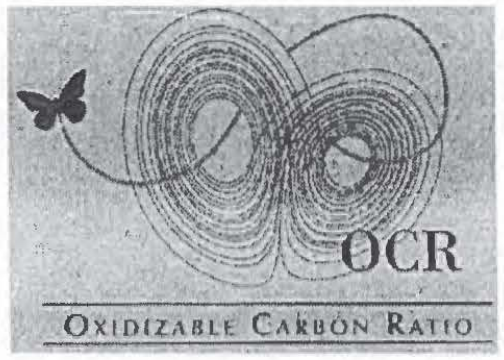

\begin{tabular}{|r|r|}
\hline Sample Id: & ACT \# 4556 \\
\hline Site Id \#: & $41-C P-245$ \\
\hline Location: & $a$ \\
\hline Feature Type: & Cultural \\
\hline Feature Designation: & $245-26$ \\
\hline Sample Recieved: & $5 / 30 / 00$ \\
\hline Calculated OCR DATE: & 3062 \\
\hline
\end{tabular}

\begin{tabular}{|c|c|c|}
\hline Sample Id: & ACT \# 4557 & \\
\hline Site Id \#: & $41-C P-245$ & \\
\hline Location: & a & \\
\hline Feature Type: & Cultural & \\
\hline Feature Designation: & $245-27$ & \\
\hline Sample Recieved: & $5 / 30 / 00$ & \\
\hline Calculated OCR DATE: & 3142 YBP(1950) & $+1-94$ \\
\hline
\end{tabular}

\begin{tabular}{|r|r|}
\hline Sample Id: & ACT\# 4558 \\
\hline Site Id \#: & $41-$ CP-245 \\
\hline Location: & a \\
\hline Feature Type: & Cultural \\
\hline Feature Designation: & $245-28$ \\
\hline Sample Recieved: & $5 / 30 / 00$ \\
\hline Calculated OCR DATE: & 3518 \\
\hline
\end{tabular}

\begin{tabular}{|c|c|c|c|}
\hline Sample Id: & ACT \# 4559 & & \\
\hline Site Id \#: & $41-C P-245$ & & \\
\hline Location: & a & & \\
\hline Feature Type: & Cultura & & \\
\hline Feature Designation: & $245-29$ & & \\
\hline Sample Recieved: & $5 / 30 / 00$ & & \\
\hline Calculated OCR DATE: & 3791 & YBP(1950) & $+/-113$ \\
\hline
\end{tabular}




\section{Calculated OCR DATE Report}

\section{For Archeological \& Environmental C}

22-Jun-00

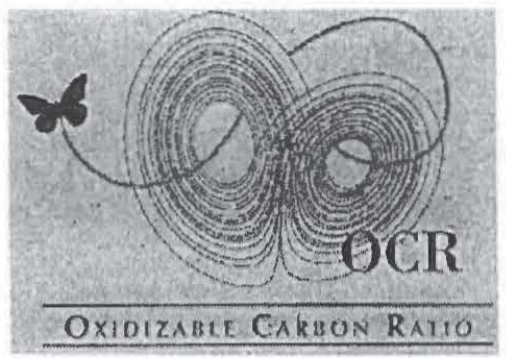

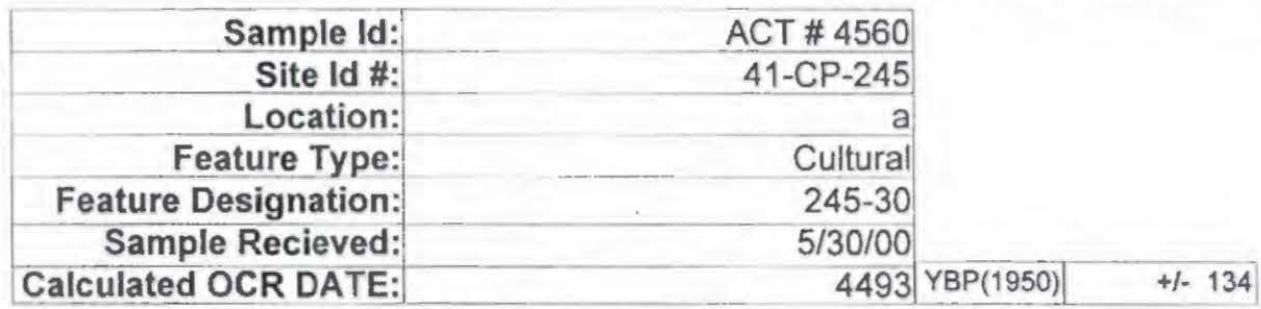

\begin{tabular}{|c|c|c|}
\hline Sample Id: & ACT \# 4561 & \\
\hline Site Id \#: & $41-\mathrm{CP}-245$ & \\
\hline Location: & a & \\
\hline Feature Type: & Cultural & \\
\hline Feature Designation: & $245-31$ & \\
\hline Sample Recieved: & $5 / 30 / 00$ & \\
\hline Calculated OCR DATE: & 5222 YBP(1950) & $+/ .156$ \\
\hline
\end{tabular}

\begin{tabular}{|r|r|}
\hline Sample Id: & ACT \# 4562 \\
\hline Site Id \#: & $41-C P-245$ \\
\hline Location: & Cultural \\
\hline Feature Type: & $245-32$ \\
\hline Feature Designation: & $5 / 30 / 00$ \\
\hline Sample Recieved: & 5181 \\
\hline Calculated OCR DATE: & YBP $(1950)$ \\
\hline
\end{tabular}




\begin{tabular}{|c|c|c|c|c|c|c|c|c|c|c|c|}
\hline Soil Depth & $\mathrm{pH}$ & \%Organic Cal Ocr Date & Very_Coarse & Coarse & Medium & Fine & Very Fine & Coarse_Silt & Fine_Silt & Sample I] Site Id \# & Location \\
\hline 10 & 5.2 & 1.343277 & .49565 & .1925 & .43361 & 13.49249 & 50.88417 & 23.3012 & 11.20036 & $4532 / 41-C P-245$ & $a$ \\
\hline 15 & 4.5 & 0.882402 & .51301 & .12906 & .48317 & 15.62666 & 52.25773 & 21.56017 & 9.4302 & $453341-C P-245$ & $a$ \\
\hline 20 & 4.3 & 0.925438 & .23064 & .12474 & .42422 & 14.45281 & 53.17133 & 21.86161 & 9.73464 & $453441-C P-245$ & a \\
\hline 25 & 4.3 & 0.758545 & .2062 & .12765 & .43134 & 14.47348 & 55.10948 & 20.99973 & 8.65211 & $453541-C P-245$ & a \\
\hline 30 & 4.2 & 0.818584 & .4696 & .10553 & .45773 & 14.85368 & 53.73535 & 21.34099 & 9.03713 & $453641-\mathrm{CP}-245$ & a \\
\hline 35 & 4. & 0.761 .587 & .22648 & .09194 & .40563 & 14.86827 & 55.58583 & 19.98188 & 8.83997 & $453741-C P-245$ & a \\
\hline 40 & 4 & 0.748550 & .20594 & .16025 & .43312 & 16.06611 & 52.46455 & 21.72374 & 8.94628 & $453841-\mathrm{CP}-245$ & $a$ \\
\hline 45 & 4.2 & 0.7588 & .34331 & .12752 & .46312 & 14.99005 & 53.38406 & 21.44288 & 9.24906 & $453941-\mathrm{CP}-245$ & a \\
\hline 50 & 4.7 & 0.752679 & .39332 & .14504 & .51703 & 16.13115 & 52.02375 & 21.66661 & 9.1231 & $454041-C P-245$ & a \\
\hline 55 & 4.1 & 0.703 .786 & .0695 & .11365 & .44887 & 14.14298 & 54.26464 & 21.15561 & 9.80475 & $454141-C P-245$ & $a$ \\
\hline 60 & 4.2 & 0.609765 & .08686 & .08964 & .41067 & 13.97104 & 54.67925 & 20.88776 & 9.87478 & $454241-C P-245$ & a \\
\hline 65 & 4 & 0.612767 & 1.35831 & .13603 & 4034 & 15.11894 & 52.83924 & 20.41681 & 9.72727 & $454341-C P-245$ & a \\
\hline 70 & 3.6 & 0.5261103 & 1.18094 & .10404 & .35023 & 13.82895 & 53.86008 & 21.25527 & 9.42049 & $4544,41-C P-245$ & a \\
\hline 75 & 3.5 & 0.4761108 & .70308 & .09067 & .34686 & 13.82268 & 53.52259 & 21.81131 & 9.70279 & $454541-C P-245$ & a \\
\hline 80 & 3.7 & 0.4591109 & .21623 & .11423 & .33658 & 13.27064 & 53.43002 & 23.01709 & 9.61521 & $454641-\mathrm{CP}-245$ & a \\
\hline 85 & 3.7 & 0.5181102 & .02326 & .10035 & .33828 & 14.6914 & 53.06608 & 21.35855 & 10.42208 & $454741-\mathrm{CP}-245$ & a \\
\hline 90 & 3.7 & 0.4361160 & .56779 & .08378 & .3012 & 14.38859 & 55.5574 & 19.71749 & 9.38374 & $454841-C P-245$ & a \\
\hline 95 & 3.8 & 0.5251241 & .87562 & .05749 & .24517 & 13.84068 & 58.43631 & 18.02051 & 8.52421 & $454941-C P-245$ & a \\
\hline 100 & 4.5 & $0.381,1445$ & .02001 & .11732 & .31744 & 14.69346 & 60.6502 & 17.59392 & 6.60764 & $455041-\mathrm{CP}-245$ & a \\
\hline 105 & 4.7 & 0.5851682 & 2.04927 & .51708 & .27079 & 13.31483 & 54.80919 & 19.39529 & 9.64355 & $4552411-\mathrm{CP}-245$ & $a$ \\
\hline 110 & 4.5 & $0.839: 1596$ & .07597 & .15195 & .33413 & 13.63452 & 62.38982 & 14.40162 & 9.01199 & $455141-\mathrm{CP}-245$ & a \\
\hline 115 & 4.1 & 0.8491856 & . & .02543 & .277 & 14.4397 & 54.84223 & 17.26194 & 13.1537 & $455341-C P-245$ & $a$ \\
\hline 120 & 3.8 & $0.954 / 1908$ & 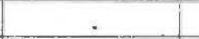 & .01349 & .1066 & 15.72772 & 56.31979 & 16.02248 & 11.80992 & $455441-C P-245$ & a \\
\hline 125 & 4.1 & 0.3342499 & .88436 & .02776 & 20111 & 23.24788 & 55.41313 & 14.09012 & 6.13565 & $455541-C P-245$ & a \\
\hline 130. & 4 & 0.5273062 & 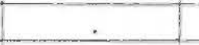 & .01315 & .30103 & 30.34912 & 51.14217 & 11.77675 & 6.41777 & $455641-C P-245$ & a \\
\hline 135 & 3.7 & 1.0373142 & . & .04865 & .53639 & 29.80667 & 51.39121 & 10.71582 & 7.50126 & $455741-C P-245$ & a \\
\hline 140 & 4.2 & 0.2493518 & 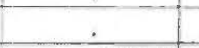 & & .2387 & 29.54876 & 56.05671 & 9.78109 & 4.37475 & $455841-C P-245$ & a \\
\hline 145 & 4.1 & 0.4263791 & .04174 & .01798 & .37692 & 34.22715 & 50.84951 & 9.16551 & 5.32118 & $455941-\mathrm{CP}-245$ & a \\
\hline 150 & 3.9 & 1.0884493 & .0191 & .04838 & .54624 & 44.9094 & 37.55173 & 9.75718 & 7.16796 & $456041-\mathrm{CP}-245$ & a \\
\hline 155 & 4 & 0.3865222 & & .0256 & .42659 & 45.06544 & 41.0418 & 9.70133 & 3.73924 & $4561,41-C P-245$ & $a$ \\
\hline 160 & 4 & 0.745181 & & & .28118 & 23.02664 & 55.89245 & 11.71279 & 9.08694 & $456241-\mathrm{CP}-245$ & $a$ \\
\hline
\end{tabular}


Appendix 4,

Radiocarbon Data Forms and Stable Isotope Analysis Form 


\section{REPORT OF RADIOCARBON DATING ANALYSES}

Dr. Timothy K. Perttula
Report Date: 10/18/2005

Material Received: 9/21/2005
Sample Data

\author{
Measured \\ Radiocarbon Age
}

$13 \mathrm{C} / 12 \mathrm{C}$

Ratio
Conventional

Radiocarbon Age $\left(^{*}\right)$

Beta - 208772

$510+/-40 \mathrm{BP}$

$-20.9 \mathrm{o} / 00$

$580+/-40 \mathrm{BP}$

SAMPLE : CP245-2

ANALYSIS : AMS-Standard delivery

MATERIAL/PRETREATMENT : (bone collagen): collagen extraction: with alkali

2 SIGMA CALIBRATION :

Cal AD 1300 to 1420 (Cal BP 650 to 530)

Beta -208773

$1320+/-40$ BP

$-27.5 \mathrm{o} / 00$

$1280+/-40 \mathrm{BP}$

SAMPLE : CP245-3

ANALYSIS : AMS-Standard delivery

MATERIAL/PRETREATMENT : (charred material): acid/alkali/acid

2 SIGMA CALIBRATION : $\quad$ Cal AD 660 to 810 (Cal BP 1280 to 1140) AND Cal AD 840 to 860 (Cal BP 1110 to 1100)

Beta - 208774

$1010+/-40 \mathrm{BP}$

$-25.6 \mathrm{o} / 00$

$1000+/-40 \mathrm{BP}$

SAMPLE : CP245-4

ANALYSIS : AMS-Standard delivery

MATERIAL/PRETREATMENT : (charred material): acid/alkali/acid

2 SIGMA CALIBRATION : $\quad$ Cal AD 980 to 1060 (Cal BP 970 to 890) AND Cal AD 1080 to 1150 (Cal BP 860 to 800)

Beta - 208775

$1730+/-40 \mathrm{BP}$

$-27.3 \mathrm{o} / \mathrm{oo}$

$1690+/-40 \mathrm{BP}$

SAMPLE : CP245-5

ANALYSIS : AMS-Standard delivery

MATERIAL/PRETREATMENT : (charred material): acid/alkali/acid

2 SIGMA CALIBRATION : $\quad$ Cal AD 250 to 430 (Cal BP 1700 to 1520)

Dates are reported as RCYBP (radiocarbon years before present, "present" = 1950A.D.). By International convention, the modern reference standard was $95 \%$ of the $\mathrm{C} 14$ content of the National Bureau of Standards' Oxalic Acid \& calculated using the Libby C14 half life (5568 years). Quoted errors represent 1 standard deviation statistics $(68 \%$ probability) \& are based on combined measurements of the sample, background, and modern reference standards.
Measured $\mathrm{C} 13 / \mathrm{C}_{12}$ ratios were calculated relative to the $\mathrm{PDB}-1$ international standard and the RCYBP ages were normalized to -25 per mil. If the ratio and age are accompanied by an ("), then the C13/C12 value was estimated, based on values typical of the material type. The quoted results are NOT calibrated to calendar years. Calibration to calendar years should be calculated using the Conventional C14 age. 


\section{CALIBRATION OF RADIOCARBON AGE TO CALENDAR YEARS}

(Variables: C13/C12=-20.9:1ab. mult=1)

Laborato ry num ber: Beta-208772

Conventional radiocarbon age: $\mathbf{5 8 0} \pm 40 \mathrm{BP}$

2 Sigma calibrated result: Cal AD 1300 to 1420 (Cal BP 650 to 530 )

( $95 \%$ probability)

In te rcept data

Intercept of radiocarbon age with calibration curve: Cal AD 1400 (Cal BP 550)

1 Sigma calibrated results: Cal AD 1310 to 1360 (Cal BP 640 to 590) and (68\% probability) Cal AD 1390 to I4I0 (Cal BP 560 to 540 )

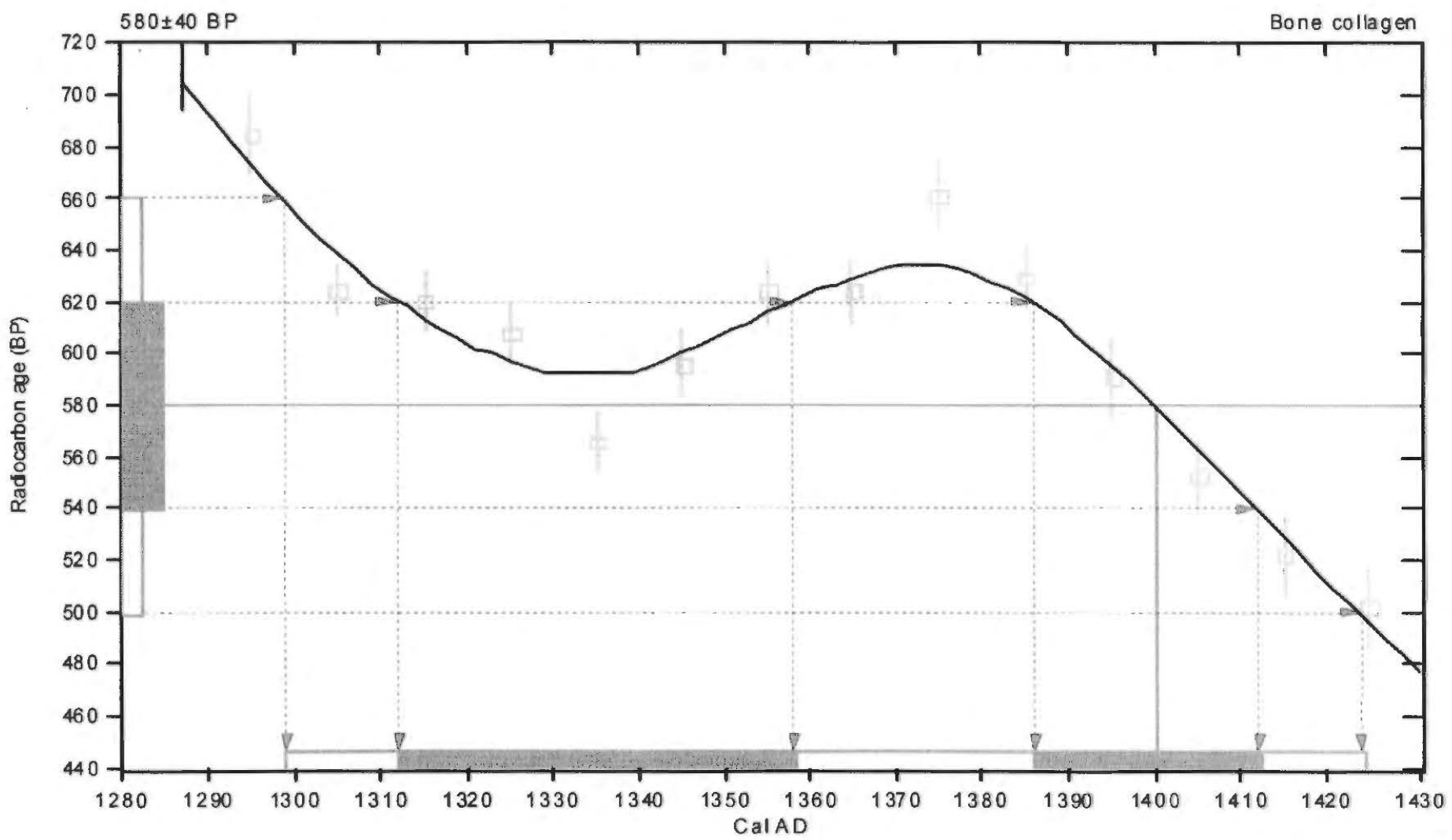

References:

Database used INTC AL 98

Calibration Database

Editorial Comment

Stuiver, M., vander Plicht, H, 1998, Radiocarbon 40(3), pxii-xiii

INTCAL 98 Radiocarbon Age Cal ibration

Stuiver, M., et. al., I998, Radiocarbon 40(3), p I04I-I083

Mathematics

A Simplified Approach to Calibrating C14 Dates

Talma, A. S., Vogel, J. C., 1993, Radiocarbon 35(2), p317-322

\section{Beta Analytic Radiocarbon Dating Laboratory}

4985 S.W.74th Court, Miami, Florida 33155.Tel: (3 05)667-5167·Fax: (305)603-0964.E-Mail: beta@radiocarbon.com 


\section{CALIBRATION OF RADIOCARBON AGE TO CALENDAR YEARS}

(Variables: C13/C $12=-27.5: 1 \mathrm{lab}$. mult $=1$ )

La borato ry num ber: Beta-208773

Conventional radiocarbon age: $1280 \pm 40 \mathrm{BP}$

2 Sigma calibrated results: Cal AD 660 to 810 (Cal BP 1280 to 1140) and

(95\% probability) Cal AD 840 to 860 (Cal BP 1110 to 1100)

In te rcept data

Intercept of radioc arbon age

with calibration curve: Cal AD 710 (Cal BP 1240)

1 Sigma calibrated result: Cal AD 680 to 780 (Cal BP 1270 to 1170 )

( $68 \%$ probability)

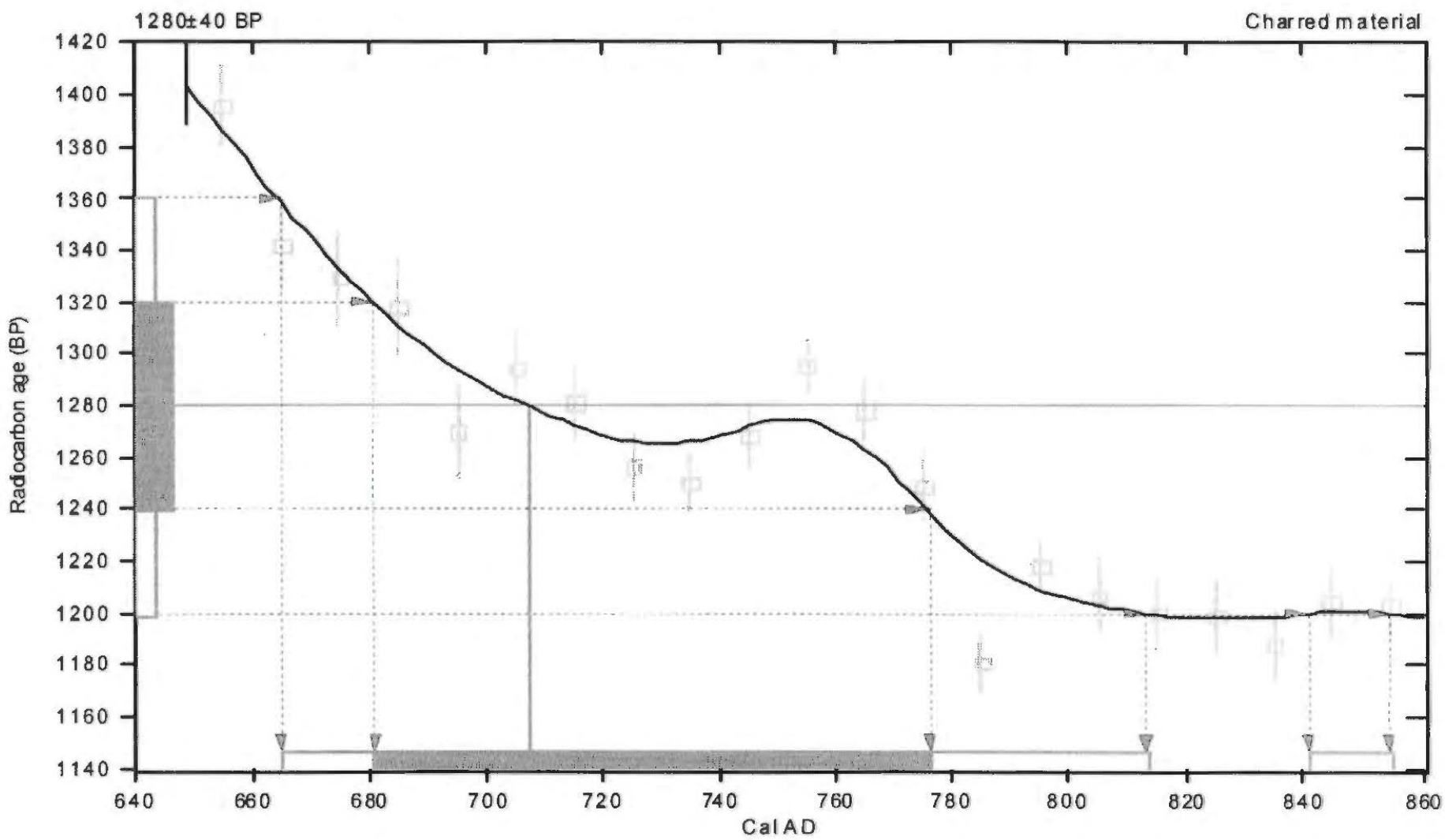

References:

Database used

INTC AL 98

Calibration Database

Editorial Comm ent

Stuiver, M., vander Plicht, H, 1998, Radiocarbon 40(3), pxii-xi ii

INTCAL 98 Radiocarbon Age Calibration

Stuiver, M., et. al., 1998, Radiocarbon 40(3), p1041-1083

Mathematics

A Simplified Approach to Calibrating CI4Dates

Talma, A. S., Vogel, J. C., 1993, Radiocarbon 35(2), p317-322

\section{Beta Analytic Radiocarbon Dating Laboratory}

4985 S.W.74th Court, Miami, Florida 33 I5 -Tel: (305)667-5167·Fax: (305)663-0964·E-Mail: beta@radiocarbon.com 


\section{CALIBRATION OF RADIOCARBON AGE TO CALENDAR YEARS}

$$
\text { (Variables: C13/C } 12=-25 \cdot 6: \text { lab. mult }=1 \text { ) }
$$

Laborato ry number: Beta-208774

Conventional radiocarbon age: $1000 \pm 40 \mathrm{BP}$

2 Sigma calibrated results: Cal AD 980 to 1060 (Cal BP 970 to 890) and

(95\% probability) Cal AD 1080 to 1150 (Cal BP 860 to 800 )

In tercept data

Intercept of radiocarbon age

with calibration curve: Cal AD 1020 (Cal BP 930)

1 Sigma calibrated result: Cal AD 1000 to 1030 (Cal BP 950 to 920)

(68\% probability)

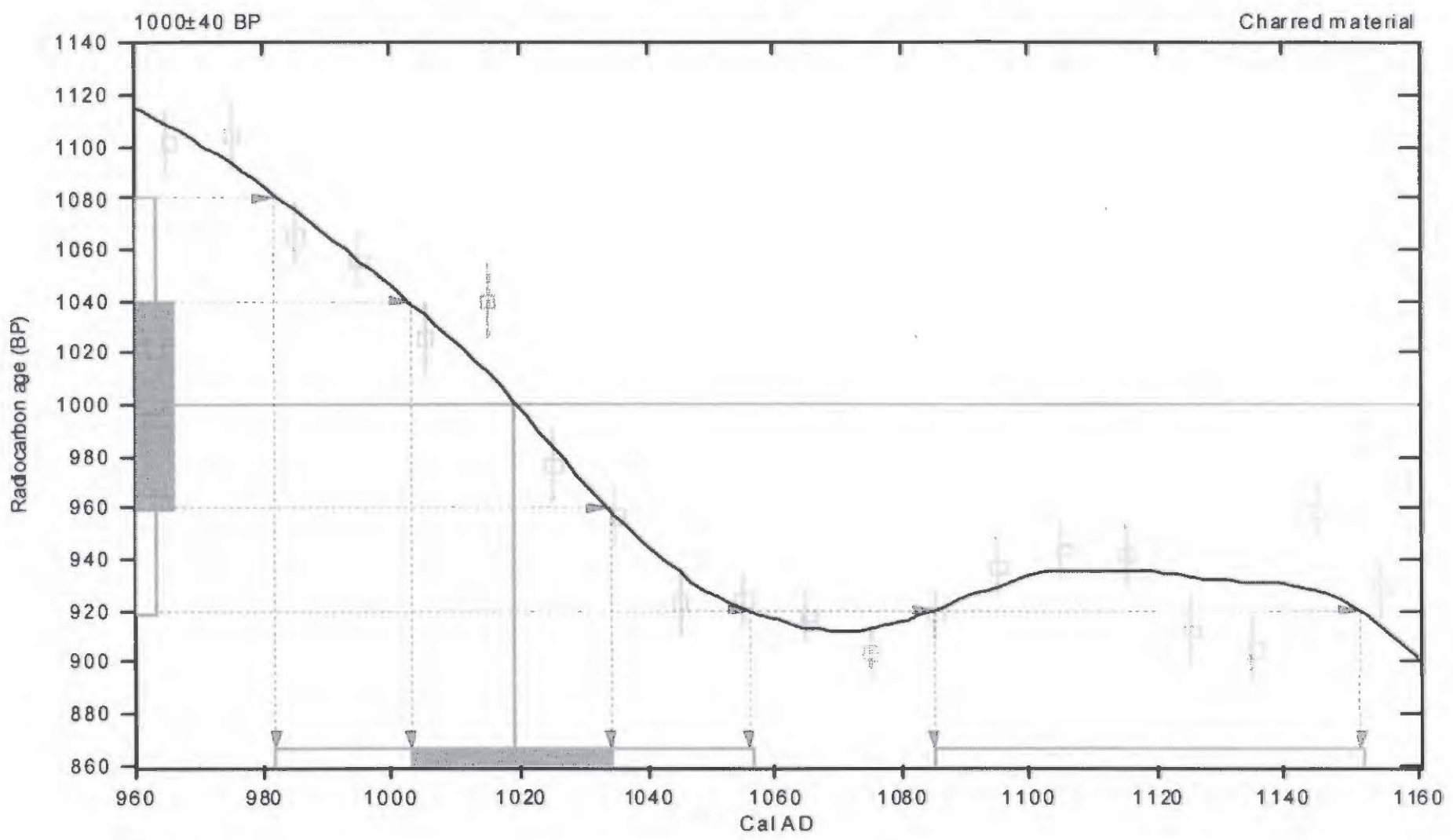

References:

Database used

INTC AL 98

Calibration Database

Editorial Comm ent

Stuiver, M., vander Plicht, H, 1998, Radiocarbon 40(3), pxii-xiii

INTCAL 98 Radiocarbon Age Calibration

Stuiver, M., et. al., 1998, Radiocarbon 40(3), p1041-1083

Mathe matics

A Simplified Approach to Calibrating CI4Dates

Talma, A. S., Vogel, J. C., 1993, Radiocarbon 35(2), p317-322

\section{Beta Analytic Radiocarbon Dating Laboratory}

4985 S.W.74th Court, Miami, Florida 33 155.Tel: (305)667-5167·Fax: (305)663-0964·E-Mail: beta@radiocarbon.com 


\section{CALIBRATION OF RADIOCARBON AGE TO CALENDAR YEARS}

(Variables: $\mathrm{C} 13 / \mathrm{C} 12=-27.3:$ lab. mult $=1$ )

La borato ry num ber: Beta-208775

Conventional radiocarbon age: $1690 \pm 40 \mathrm{BP}$

2 Sigma calibrated result: Cal AD 250 to 430 (Cal BP 1700 to 1520) ( $95 \%$ probability)

In te rcept data

Intercept of radiocarbon age

with calibration curve: Cal AD 380 (Cal BP 1570)

1 Sigma calibrated result: Cal AD 330 to 410 (Cal BP 1620 to 1540 )

(68\% probability)

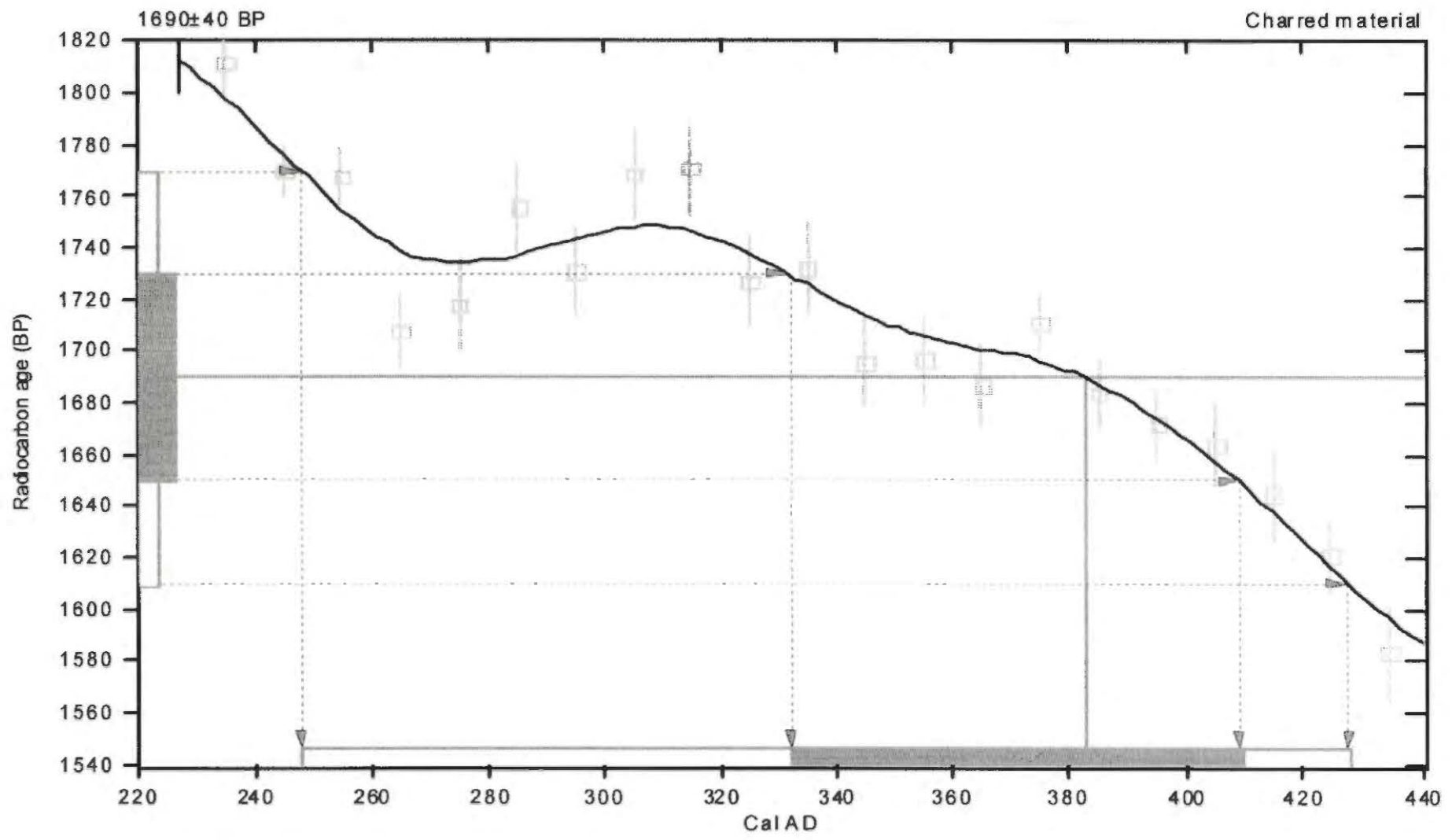

References:

Database used

INTC AL 98

Calibration Database

Editorial Comm ent

Stuiver, M., vander Plicht, H, 1998, Radiocarbon 40(3), pxii-xiii

INTCAL 98 Radiocarbon Age Cal ibration

Stuiver, M., et. al., 1998, Radiocarbon 40(3), p1041-1083

Mathe matics

A Simplified Approach to Calibrating C14Dates

Talma, A.S., Vogel, J, C., 1993, Radiocarbon 35(2), p3I7-322 


\section{BETA ANALYTIC INC.}

\section{DR. M.A. TAMERS and MR. D.G. HOOD}

UNIVERSITY BRANCH

4985 S.W. 74 COURT

MIAMI, FLORIDA, USA 33155

PH: 305/667-5167 FAX: 305/663-0964

E-MAIL: beta@radiocarbon.com

\section{REPORT OF RADIOCARBON DATING ANALYSES}

Dr. Timothy K. Perttula

Austin, Texas
Report Date: May 24, 2000

Material Received: April 7, 2000
Dates are reported as RCYBP (radiocarbon years before present, "present" = 1950A.D.). By International convention, the modern reference standard was $95 \%$ of the C14 content of the National Bureau of Standards' Oxalic Acid \& calculated using the Libby $\mathrm{C}_{14}$ half life ( 5558 years). Quoted errors represent 1 standard deviation statistics ( $68 \%$ probability) \& are based on combined measurements of the sampls, background, and modern reference standards.
Measured $\mathrm{C} 13 / \mathrm{C} 12$ ratios were calculated relative to the PDB-1 international standard and the RCYBP ages were normalized to -25 per mil. If the ratio and age are accompanied by an ("), then the C13/C12 value was estimated, based on values typical of the material type. The quoted results are NOT calibrated to calendar years. Calibration to calendar years should be calculated using the Conventional $\mathrm{C}_{14}$ age. 
Appendix 6,

Inventory of Recovered Artifacts 
Only limited archeological work has been carried out at the Tiddle Lake site mound (41CP246) since it was recorded by Bo Nelson. The circular mound, about $20 \mathrm{~m}$ in diameter, has been cut by a gravel road (Figure A.5.1). From the surface of the mound, we found a plain ceramic body sherd and another sherd (from a cooking jar) with parallel brushing marks on it.
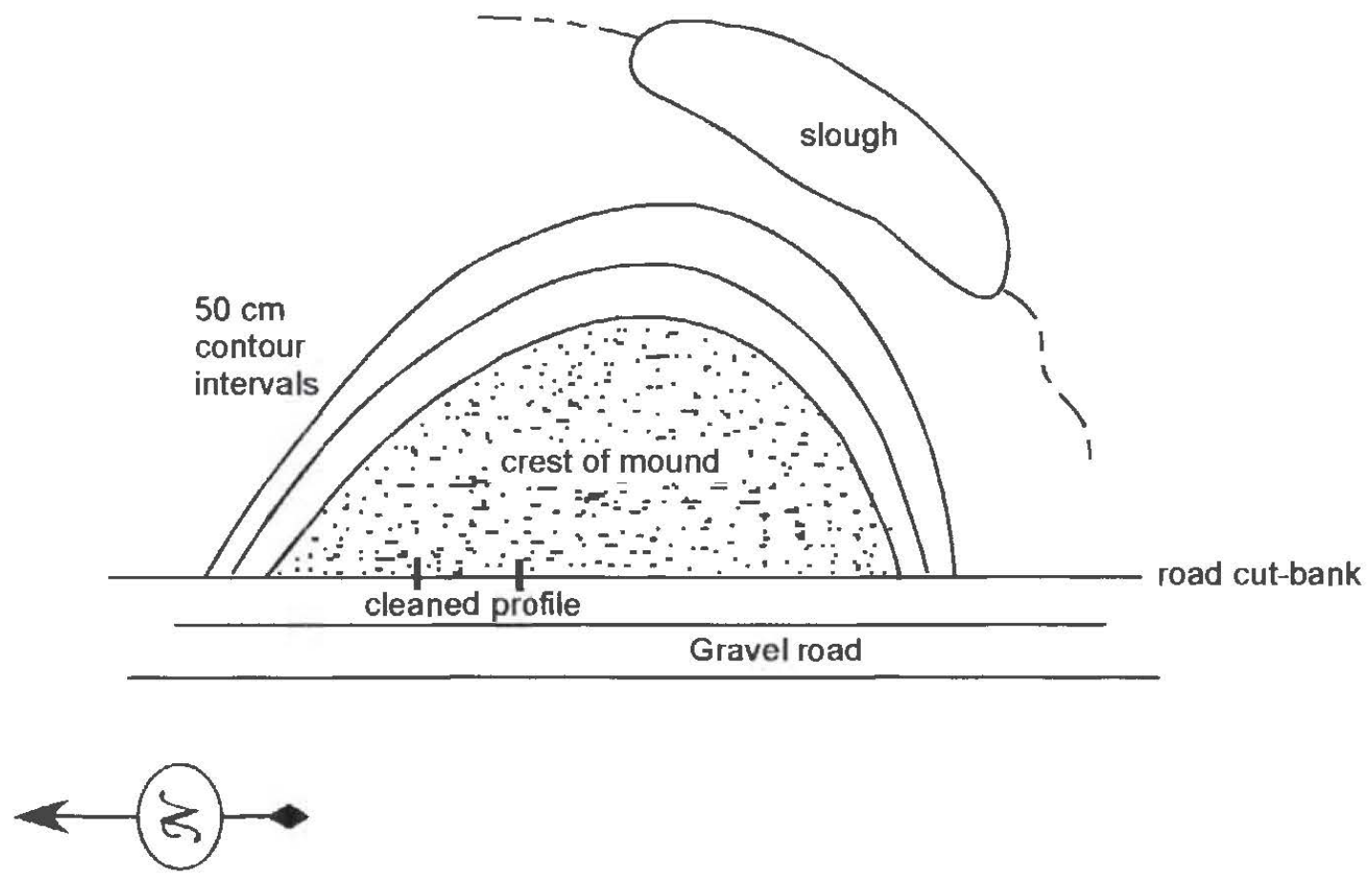

Figure A.5.1. Map of the Tiddle Lake Mound site.

The mound has a massive sandy mound fill about $70 \mathrm{~cm}$ in thickness (Figure A.5.2). Three OCR samples were taken from a profile of the mound fill along the road cut, and the OCR dates range from A.D. 1477-1539 (Perttula 2005: Table 11-3). The Tiddle Lake mound is one of 12 Titus phase mounds known in the Big Cypress Creek basin. 


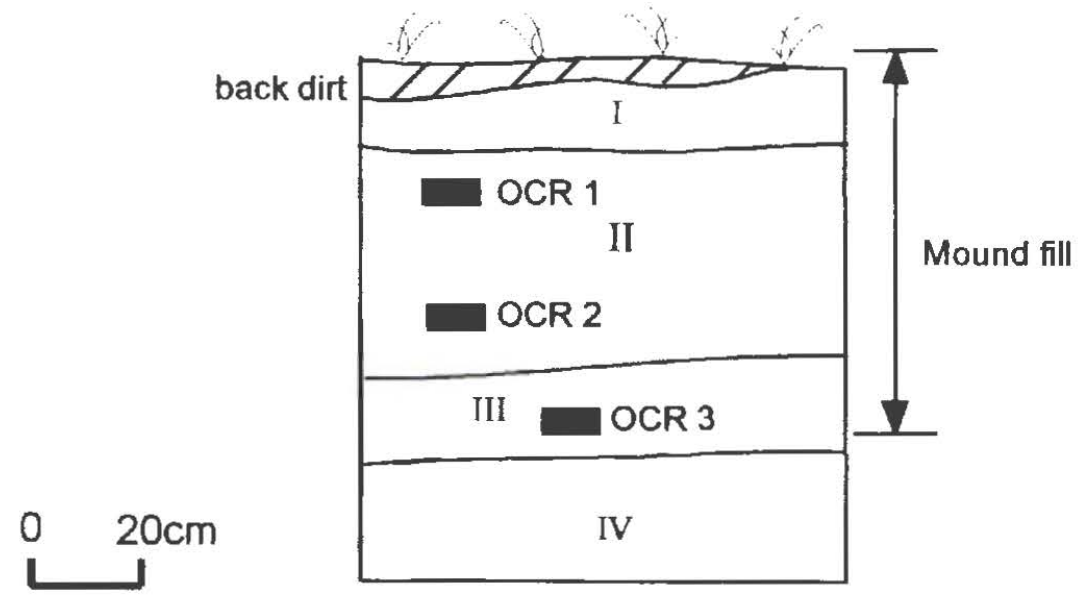

Figure A.5.2. Cut bank profile and OCR samples. 


\section{Appendix 6,}

\section{Inventory of Recovered Artifacts}


Surface: $\quad 1$ quartzite mano; 1 ferruginous sandstone pitted stone; 1 novaculite lithic debris; 1 hematite lithic debris (from polished groundstone tool, probably a gouge); 1 quartzite lithic debris; 10 lithic debris; 1 plain rim sherd; 9 plain body sherds; 1 exterior red-slipped bottle body sherd; 3 parallel brushed body sherd; 1 noded body sherd; 1 appliqued body sherd; 1 FCR

Looter Holes

LH-3 (Burial Pit \#1)

LH-16

LH-41

Spoil Pile Unit

Shovel Tests

ST 1, 0-20 cm:

ST 1, 20-40 cm:

ST 1, 40-60 cm:

ST $1,60-80 \mathrm{~cm}$ :

ST 1,80-100 cm:

ST 2, 0-20 cm:

ST $2,20-40 \mathrm{~cm}$ :

ST 2, 40-60 cm:

ST 2, 60-80 cm:

ST 2, 80-100 cm:

ST 3, 0-20 cm:

ST $3,20-40 \mathrm{~cm}$ :

ST 3, 40-60 cm:

ST 3, 60-80 cm:

ST $3,80-100 \mathrm{~cm}$ :

ST 4, 0-20 cm:

ST 4, 20-40 cm:
1 parallel incised body sherd; 2 parallel brushed body sherds; 1 plain rim sherd; 10 plain body sherds; 4 pieces of burned clay; 1 quartzite flake tool; 1 red chert lithic debris; 3 gray chert lithic debris; 21 quartzite lithic debris

1 horizontal engraved bottle sherd (Hickory Engraved)

3 lithic debris

2 Yarbrough dart points; 1 quartzite core; 11 lithic debris; 2 FCR

1 plain body sherd; 2 lithic debris

2 plain body sherds; 4 lithic debris

3 lithic debris

1 perforator; 3 lithic debris

1 plain body sherd; 1 incised-punctated rim sherd; 5 lithic debris

1 exterior red-slipped bottle sherd; 1 daub; 10 lithic debris 1 incised-punctated body sherd; 7 plain body sherds; 1 burned clay; 11 lithic debris

1 appliqued rim sherd; 1 plain body sherd; 2 burned clay; 9 lithic debris; 1 FCR

1 plain body sherd; 1 burned clay; 8 lithic debris

1 burned clay; 4 lithic debris

3 plain body sherds; 2 burned clay pieces; 15 lithic debris

3 plain body sherds; 1 piece of bumed clay; 7 lithic debris 1 diagonal incised body sherd; 1 piece of daub; 1 piece of burned clay; 1 ferruginous sandstone biface; 9 lithic debris 1 burned clay; 4 lithic debris

2 lithic debris; 1 FCR

1 lithic debris

1 pitted stone; 9 lithic debris 
ST 4, 40-60 cm:

ST 4, 60-80 cm:

ST 4, 80-100 cm:

ST 5, 0-20 cm:

ST $5,20-40 \mathrm{~cm}$ :

ST 5, 40-60 cm:

ST 5, 60-80 cm:

ST 5, 80-100 cm:

ST 6, 0-20 cm:

ST 6, 20-40 cm:

ST 6, 40-60 cm:

ST 6, 60-80 cm:

ST 6, 80-100 cm:

ST $6,100-120 \mathrm{~cm}$ :

ST 7, 0-20 cm:

ST 7, $20-40 \mathrm{~cm}$ :

ST 7, $40-60 \mathrm{~cm}$ :

ST 7, 60-80 cm:

ST 7, 80-100 cm:

ST 8, 0-20 cm:

ST $8,20-40 \mathrm{~cm}$ :

ST $8,40-60 \mathrm{~cm}$ :

ST 8, 60-80 cm:

ST 8, 80-100 cm:

ST 9, 0-20 cm:

ST 9, 20-40 cm:

ST 9, 40-60 cm:

ST 9, 60-72 cm:

ST 10, 20-40 cm:

ST 10, 40-60 cm:
1 plain body sherd; 1 parallel incised body sherd; 5 lithic debris

4 lithic debris

1 piece of daub; 1 flake tool; 5 lithic debris

1 plain body sherd; 1 arrow point preform; 1 core; 7 lithic debris

3 red-slipped body sherds; 1 parallel-brushed body sherd; 2 plain body sherds; 11 daub; 3 lithic debris

1 lithic debris

3 parallel incised body sherds; 1 punctated body sherd; 1

lithic debris

2 lithic debris

4 lithic debris

1 ferruginous sandstone ground stone tool; 1 lithic debris

5 lithic debris

6 lithic debris

1 arrow point preform; 5 lithic debris

2 quartzite lithic debris; 1 petrified wood lithic debris

4 lithic debris

4 lithic debris

1 parallel brushed body sherd; 3 lithic debris

2 lithic debris

5 lithic debris

2 quartzite lithic debris

2 plain body sherds; 1 novaculite lithic debris; 2 quartzite lithic debris

1 horizontal engraved bottle sherd; 3 quarrzite lithic debris

1 carinated bowl sherd with horizontal engraved line; 2 quartzite lithic debris

1 bottle sherd with engraved triangle element; 4 quartzite

lithic debris; 1 brown chert lithic debris

1 plain body sherd; 1 quartzite flake tool

1 burned clay piece; 4 quartzite lithic debris

1 quartzite lithic debris

1 parallel-diagonal incised body sherd; 1 tool punctated body sherd; 1 novaculite lithic debris; 2 quartzite lithic debris

2 quartzite lithic debris

1 quartzite lithic debris 
ST 10, 60-80 cm:

ST 10, $80-100 \mathrm{~cm}$ :

ST 11, 0-20 cm:

ST 11, 20-40 cm:

ST 11, 40-60 cm:

ST $11,60-80 \mathrm{~cm}$ :

ST 11, 80-100 cm:

ST 12, 20-40 cm:

ST $12,40-60 \mathrm{~cm}$ :

ST 12, 80-100 cm:

ST $13,20-40 \mathrm{~cm}$ :

ST 13, 40-60 cm:

ST 13, 60-80 cm:

ST $13,80-100 \mathrm{~cm}$ :

ST 14, 0-10 cm:

ST 14, 10-20 cm:

ST 14, 20-30 cm:

ST $14,30-40 \mathrm{~cm}$ :

ST $14,40-50 \mathrm{~cm}$ :

ST $14,50-60 \mathrm{~cm}$ :

ST $14,60-70 \mathrm{~cm}$ :

ST $14,70-80 \mathrm{~cm}$ :

ST 14, 80-90 cm:

ST 14, 90-100 cm:

ST 15, 0-10 cm:

ST 15, 10-20 cm:
1 tool punctated body sherd; 1 curvilinear engraved bottle body sherd; 1 novaculite lithic debris; 1 ferruginous sandstone lithic debris

1 curvilinear engraved body sherd; 2 quartzite lithic debris

1 quartzite dart point tip; 6 quartzite lithic debris; 1

petrified wood lithic debris; 1 yellowish-red chert lithic debris

1 single straight engraved line body sherd; 1 plain body sherd; 7 quartzite lithic debris

1 diagonal engraved carinated bowl sherd; 5 quartzite lithic debris; 1 petrified wood lithic debris

1 diagonal incised rim sherd; 3 quartzite lithic debris

1 exterior red-slipped body sherd; 1 fingernail punctated body sherd; 1 daub; 3 quartzite lithic debris; 1 novaculite lithic debris

I plain body sherd; 3 quartzite lithic debris

1 quartzite lithic debris

2 quartzite lithic debris

1 parallel brushed body sherd; 1 plain body sherd; 1 quartzite lithic debris; 1 dark brown chert lithic debris 1 zoned hatched engraved bottle sherd; 1 novaculite lithic debris

1 quartzite tested cobble; 3 quartzite lithic debris

3 quartzite lithic debris; 1 black chert lithic debris; 1 white chert lithic debris

1 piece of daub; 2 quartzite lithic debris

5 quartzite lithic debris

1 plain body sherd; 1 plain base sherd; 1 quartzite tested cobble; 3 quartzite lithic debris; 1 gray chert lithic debris 1 plain body sherd; 2 burned clay pieces; 1 quartzite pitted stone; 3 quartzite lithic debris; 1 dark gray chert lithic debris; 1 red chert lithic debris 2 quartzite lithic debris 5 quartzite lithic debris: 1 red chert lithic debris 4 quartzite lithic debris 1 plain body sherd; 1 burned clay piece; 2 quartzite lithic debris 1 quartzite lithic debris; 1 petrified wood lithic debris 1 quartzite lithic debris

1 plain body sherd; 3 quartzite lithic debris 1 piece of burned clay; 5 quartzite lithic debris 
ST 15, 20-30 cm:

ST 15, 30-40 cm:

ST 15, 40-50 cm:

ST 15, 50-60 cm:

ST $15,60-70 \mathrm{~cm}$ :

ST 15, 70-80 cm:

ST 15, 80-90 cm:

ST $15,90-100 \mathrm{~cm}$ :

ST $16,0-10 \mathrm{~cm}$ :

ST $16,10-20 \mathrm{~cm}$ :

ST 16, 20-30 cm:

ST $16,30-40 \mathrm{~cm}$ :

ST $16,40-50 \mathrm{~cm}$ :

ST $16,50-60 \mathrm{~cm}$ :

ST $16,60-70 \mathrm{~cm}$ :

ST $16,70-80 \mathrm{~cm}$ :

ST $16,80-90 \mathrm{~cm}$ :

ST 17, 0-10 cm:

ST $17,10-20 \mathrm{~cm}$ :

ST 17, 20-30 cm:

ST $17,30-40 \mathrm{~cm}$ :

ST 17, 40-50 cm:

ST 17, 50-60 cm:

ST $17,60-70 \mathrm{~cm}$ :

ST $17,70-80 \mathrm{~cm}$ :

ST $17,80-90 \mathrm{~cm}$ :

ST $17,90-100 \mathrm{~cm}$ :

ST 18, 0-10 cm:

ST $18,10-20 \mathrm{~cm}$ :

ST $18,20-30 \mathrm{~cm}$ :

ST $18,30-40 \mathrm{~cm}$ :

ST $18,40-50 \mathrm{~cm}$ :
6 quartzite lithic debris

1 plain body sherd; 4 quartzite lithic debris; 1 petrified wood lithic debris

1 quartzite lithic debris

1 piece of burned clay; 1 arrow point tip; 3 quartzite lithic debris

1 plain body sherd; 5 quartzite lithic debris; 1 FCR (41.9 g)

6 quartzite lithic debris

1 body sherd with triangular engraved element; 1 plain body sherd; 1 petrified wood lithic debris; 1 quartzite lithic debris; 1 grayish-brown lithic debris; 1 yellowish-brown lithic debris

3 plain body sherds; 1 ferruginous sandstone gouge; 2 quartzite lithic debris

1 quartzite lithic debris

1 reddish-brown chert lithic debris

1 quartzite lithic debris

1 plain body sherd; 1 quartzite lithic debris; 1 petrified wood lithic debris

1 quartzite lithic debris

1 quartzite lithic debris

1 plain body sherd

1 quartzite multi-platform core; 1 novaculite lithic debris

1 quartzite lithic debris

1 plain body sherd; 1 novaculite lithic debris; 2 quartzite lithic debris

2 quartzite lithic debris

4 quartzite lithic debris

1 parallel brushed body sherd; 1 piece of daub; 3 quartzite lithic debris

3 quartzite lithic debris; 1 gray chert lithic debris

1 parallel engraved body sherd; 1 quartzite lithic debris

3 quartzite lithic debris

2 quartzite lithic debris; 1 novaculite lithic debris

2 quartzite lithic debris

2 plain body sherds; 4 quartzite lithic debris

1 exterior red-slipped body sherd

6 plain body sherds; 2 quartzite lithic debris

3 plain body sherds; 3 quartzite lithic debris

1 plain body sherd; 3 quartzite lithic debris; 1 dark gray

chert lithic debris

1 petrified wood lithic debris 
ST $18,50-60 \mathrm{~cm}$ :

ST 18, 60-70 cm:

ST $18,80-90 \mathrm{~cm}$ :

ST $18,90-100 \mathrm{~cm}$ :

ST 19, 0-10 cm:

ST 19, 10-20 cm:

ST 19, 20-30 cm:

ST 19, 30-40 cm:

ST 19, 40-50 cm:

ST 19, 50-60 cm:

ST 19, 60-70 cm:

ST 19, 70-80 cm:

ST 19, 80-90 cm:

ST $20,10-20 \mathrm{~cm}$ :

ST 20, 20-30 cm:

ST 20, 30-40 cm:

ST 20, 40-50 cm:

ST $20,50-60 \mathrm{~cm}$ :

ST $20,60-70 \mathrm{~cm}$ :

ST 20, 70-80 cm:

ST $20,80-90 \mathrm{~cm}$ :

ST 20, 90-100 cm:

ST 23, 0-20 cm:

ST $23,20-30 \mathrm{~cm}$ :

ST $23,30-40 \mathrm{~cm}$ :

ST 23, 40-50 cm:

ST 23, 50-60 cm:

ST 23, 60-70 cm:

ST 24, 10-20 cm: ST 24, 20-30 cm:
1 parallel brushed body sherd; 1 bottle sherd with redslipped and noded exterior; 1 single platform quartzite core; 4 quartzite lithic debris

1 petrified wood lithid debris; 1 brown chert lithic debris; 1 quartzite lithic debris

1 parallel brushed body sherd; 1 plain body sherd; 2 quartzite lithic debris

1 quartzite lithic debris

1 quartzite lithic debris

4 quartzite lithic debris; 1 red chert lithic debris

1 gray chert lithic debris; 1 burned clay piece

1 yellowish-brown chert lithic debris

2 plain body sherds; 1 quartzite lithic debris

1 plain body sherd; 2 quartzite lithic debris

1 parallel engraved body sherd; 1 plain body sherd

1 single straight engraved line body sherd; 1 Spiro or Holly

Engraved bottle sherd; 1 plain body sherd; 2 quartzite lithic debris; 1 petrified wood lithic debris; 1 red chert lithic debris

1 parallel incised body sherd; 1 quartzite lithic debris; 1 dark gray chert lithic debris

2 plain body sherds; 1 quartzite lithic debris; 1 dark brown chert lithic debris

1 parallel brushed body sherd; 2 quartzite lithic debris

1 parallel incised body sherd; 3 quartzite lithic debris

1 parallel brushed-incised body sherd; 2 plain body sherds;

2 quartzite lithic debris

1 straight incised line body sherd; 1 horizontal brushed rim sherd; 4 quartzite lithic debris; 1 red chert lithic debris

8 quartzite lithic debris; 1 red chert lithic debris

4 quartzite lithic debris

I novaculite lithic debris; 1 quartzite lithic debris

3 quartzite lithic debris

1 plain body sherd; 2 burned clay; 16 lithic debris

8 lithic debris; 1 FCR

1 diagonal incised rim sherd; 19 lithic debris

13 lithic debris

1 interior/exterior red-slipped body sherd; 3 burned clay; 11

lithic debris

8 lithic debris

2 lithic debris

3 lithic debris 
ST 24, 30-40 cm:

ST 24, 40-50 cm:

ST 25, 0-10 cm:

ST 25, 10-20 cm:

ST 25, 20-30 cm:

ST 25, 30-40 cm:

ST 25, 50-60 cm:

ST 26, 0-10 cm:

ST 26, 10-20 cm:

ST 26, 20-30 cm:

ST $26,30-40 \mathrm{~cm}$ :

ST 26, 40-50 cm:

ST 27, 0-10 cm:

ST 27, 10-20 cm:

ST $27,20-30 \mathrm{~cm}$ :

ST 27, 30-40 cm:

ST 27, 40-50 cm:

ST 27, 50-60 cm:

ST 27, 60-70 cm:

ST $27,70-80 \mathrm{~cm}$ :

ST 28, 0-20 cm:

ST 28, 20-40 cm:

ST $28,40-60 \mathrm{~cm}$ :

ST $28,60-80 \mathrm{~cm}$ :

ST 29, 0-20 cm:

ST $29,20-40 \mathrm{~cm}$ :

ST $29,40-60 \mathrm{~cm}$ :

ST 29, 60-82 cm:

Hand-Excavated Units

Unit 1, 0-10 cm:

Unit 1, 10-20 cm:
2 lithic debris

2 lithic debris

6 lithic debris

1 horizontal engraved rim sherd; 6 lithic debris

1 lithic debris

1 lithic debris

1 lithic debris

2 plain body sherds; 2 lithic debris

1 plain body sherd; 1 lithic debris

1 lithic debris

3 lithic debris

1 pitted stone-mano; 1 lithic debris

8 lithic debris

1 burned clay; 4 lithic debris

1 burned clay; 3 lithic debris

1 plain body sherd; 3 lithic debris

1 plain body sherd; 1 parallel stemmed novaculite arrow point; 3 lithic debris

1 opposed incised body sherd; 5 lithic debris

3 lithic debris

1 lithic debris

1 cross-hatched incised body sherd; 1 carinated bowl circular engraved body sherd; 3 lithic debris

1 hatched zone bottle sherd; 1 pendant triangle engraved bottle sherd; 4 lithic debris

1 parallel brushed body sherd; 4 lithic debris; 1 FCR

7 lithic debris

4 lithic debris

1 tool punctated rows rim sherd; 1 plain body sherd; 1 burned clay; 4 lithic debris

2 lithic debris

1 plain body sherd
1 plain body sherd; I exterior red-slipped body sherd; 1 rim sherd with horizontal brushing and tool punctated row above brushing; 1 hematite lithic debris; 2 red chert lithic debris; 1 gray chert lithic debris; 9 quartzite lithic debris 1 rim with engraved pendant triangles; 1 rectilinear incised body sherd; 1 bottle sherd with straight engraved line; 2 
Unit 1, 20-30 cm:

plain body sherds; 3 burned clay pieces; 1 quartzite multiplatform core; 19 quartzite lithic debris; 2 gray lithic debris; 1 dark brown chert lithic debris; 1 brown chert lithic debris; 1 red chert lithic debris 1 parallel brushed body sherd; 1 opposed incised body sherd; 1 free tool punctated body sherd; 1 parallel incised body sherd; 1 diagonal incised rim sherd; 1 tool punctated rows body sherd; 1 rim with diagonal brushing and tool punctated row below lip; 1 corner-notched arrow point, quartzite; 1 quartzite arrow point fragment; 44 quartzite lithic debris; 3 brown chert lithic debris; 1 novaculite lithic debris; 2 burned clay pieces; 6 plain body sherds

Unit 1, $31 \mathrm{~cm}$ (in looter disturbance): 1 dart point

Unit 1, 30-40 cm:

Unit 1, 40-50 cm:

Unit 1, 50-60 cm:

Unit 1, 60-70 cm:

Unit 21, 0-10 cm: Unit 21, 10-20 cm: Unit 21, 20-30 cm: Unit 21, 30-40 cm:

Unit $21,40-50 \mathrm{~cm}$ :
3 plain body sherds; 1 exterior red-slipped body sherd; 1 tool punctated rim sherd; 3 burned clay pieces; 3 petrified wood lithic debris; 32 quartzite lithic debris; 1 red chert lithic debris; 5 gray chert lithic debris; 3 novaculite lithic debris; 1 brown chert lithic debrs; 3 petrified wood lithic debris; 40 quartzite lithic debris; 1 novaculite lithic debris; 1 gray chert lithic debris; 1 reddish-brown chert lithic debris; 1 red chert lithic debris; 8 plain body sherds

2 plain rims; 3 plain body sherds; 3 parallel incised body sherds; 1 exterior red-slipped body sherd; 1 quartzite dart point fragment; 1 petrified wood lithic debris; 31 quartzite lithic debris; 1 dark gray chert lithic debris; 1 red chert lithic debris; 3 reddish-brown chert lithic debris; 1 red chert multi-platform core 2 parallel brushed body sherds; 1 interior-exterior redslipped carinated bowl sherd; 1 diagonal engraved rim sherd; 3 plain body sherds; 1 Gary dart point, quartzite; single platform quartzite core; 19 quartzite lithic debris; 1 brown chert lithic debris; 1 gray chert lithic debris; 1 FCR $(21.2 \mathrm{~g})$

6 lithic debris

2 plain body sherds; 1 burned clay; 12 lithic debris 1 plain body sherd; 2 burned clay; 22 lithic debris 1 parallel brushed body sherd; 1 plain rim sherd; 1 plain body sherd; 1 burned clay; 28 lithic debris; 1 Gary dart point; 1 corner-notched arrow point; I parallel stemmed arrow point; 1 biface fragment 1 exterior red-slipped bottle body sherd; 1 tool punctated body sherd; 1 carinated bowl horizontal engraved body sherd; 1 parallel brushed body sherd; 1 parallel-diagonal 
Unit 21, 50-60 cm:

Unit 21, 60-70 cm:

Unit $21,70-80 \mathrm{~cm}$ :

Unit 21, 80-90 cm:

Unit 21, 90-100 cm: engraved body sherd; 8 plain body sherds; 3 burned clay; 25 lithic debris

1 interior-exterior red-slipped body sherd; 1 cane punctated rim sherd; 1 parallel brushed-incised-appliqued ridge body sherd; 8 plain body sherds; 3 plain rim sherds; 1 biface fragment; 33 lithic debris

1 parallel brushed body sherd; 1 diagonal incised rim sherd; 1 plain rim sherd; 11 plain body sherds; 1 clay coil; 2 burned clay; 1 bilateral flake tool; 1 Gary dart point; 2 biface fragments; 1 arrow point preform; 42 lithic debris; 2 FCR 1 interior/exterior red-slipped body sherd; 1 Pease Brushed_incised body sherd (incised-appliqued); 7 plain body sherds; 1 stemmed arrow point; 1 Gary dart point; 1 bilateral flake tool; 1 biface; 1 mano; I FCR; 39 lithic debris 1 parallel brushed body sherd; 1 parallel brushed-incisedtool punctated body sherd; 1 plain rim sherd; 1 cornernothced arrow point; 1 Gary dart point; 19 lithic debris; 1 FCR 1 incised-punctated rim sherd; 1 parallel incised body sherd; 1 plain rim sherd; 5 plain body sherds; 1 burned clay; 1 biface; 25 lithic debris

\section{Unit 21, Fine-screen}

10-20 cm: 2 burned clay; 2 lithic debris

20-30 cm: 1 plain body sherd; 3 burned clay; 5 lithic debris

40-50 cm: 1 plain body sherd; 3 burned clay; 11 lithic debris

50-60 cm: 1 burned clay; 1 lithic debris

60-70 cm: 4 lithic debris

70-80 cm: 1 plain body sherd; 1 lithic debris

80-90 cm: 5 lithic debris; 3 FCR

90-100 cm: 4 lithic debris

Unit 22, 0-10 cm:

Unit 22, 10-20 cm:

Unit 22, 20-30 cm:

Unit 22, 30-40 cm:
1 parallel engraved body sherd; 1 parallel incised body sherd; 1 parallel brushed-tool punctated row body sherd; 2 plain body sherds; 3 lithic debris 1 parallel brushed body sherd; 1 parallel engraved body sherd; 1 plain body sherd 1 burned clay; 5 lithic debris 1 parallel brushed body sherd; 4 plain body sherds; 2 burned clay; 10 lithic debris 1 horizontal brushed-tool punctated rim sherd; 1 parallel incised body sherd; 2 daub; 2 burned clay; 1 parallel stemmed dart point; 1 Catahoula arrow point; 2 lithic debris 
Unit 22, 40-50 cm:

Unit 22A, 0-10 cm:

Unit 22A, 10-20 cm:

Unit 22A, $30-40 \mathrm{~cm}$ :

Unit 22A, 40-50 cm:

Unit 22/22A, 50-60 cm:

Unit 22/22A, 60-70 cm:

Unit 22/22A, $70 \mathrm{~cm}$ :
1 tool punctated body sherd; 1 parallel brushed-incised body sherd; 2 plain body sherds; 7 lithic debris

1 plain scalloped rim shend; 1 parallel brushed body sherd; 2 lithic debris

3 plain body sherds; 1 burned clay; 1 novaculite flake tool; 3 lithic debris

1 parallel brushed body sherd; 2 plain body sherds; 6 lithic debris

2 plain body sherds; 4 lithic debris

2 parallel brushed body sherds; 1 exterior red-slipped body sherd; 1 single straight engraved line body sherd; 1 tool punctated body sherd; 6 plain body sherds; 1 Yarbrough dart point, 22 lithic debris 1 parallel brushed body sherd; 1 diagonal engraved rim sherd; 2 plain body sherds; 9 lithic debris; 1 core 1 horizontal engraved carinated bowl body sherd 